DOE/EIA-0592

Distribution Category UC-950

\title{
Decommissioning of U.S. Uranium Production Facilities
}

February 1995

Energy Information Administration

Office of Coal, Nuclear, Electric and Alternate Fuels

U.S. Department of Energy

Washington, DC 20585

This report was prepared by the Energy Information Administration, the independent statistical and analytical agency within the Department of Energy. The information contained herein should not be construed as advocating or reflecting any policy position of the Department of Energy or of any other organization. 


\section{Contacts}

This report was prepared in the Office of Coal, Nuclear, Electric and Alternate Fuels by the Analysis and Systems Division. General information regarding this publication may be obtained from John Geidl (202/2545570), Director, Office of Coal, Nuclear, Electric and Alternate Fuels; Robert M. Schnapp (202/254-5392),
Director, Analysis and Systems Division, or Z.D. Nikodem (202/254-5550), Branch Chief, Energy Resources Assessment Branch. Specific questions regarding the preparation and content of this report should be directed to Taesin Chung (202/254-5556), project manager, and John Moens (202/254-5388). 


\section{DISCLAIMER}

This report was prepared as an account of work sponsored by an agency of the United States Government. Neither the United States Government nor any agency thereof, nor any of their employees, make any warranty, express or implied, or assumes any legal liability or responsibility for the accuracy, completeness, or usefulness of any information, apparatus, product, or process disclosed, or represents that its use would not infringe privately owned rights. Reference herein to any specific commercial product, process, or service by trade name, trademark, manufacturer, or otherwise does not necessarily constitute or imply its endorsement, recommendation, or favoring by the United States Government or any agency thereof. The views and opinions of authors expressed herein do not necessarily state or reflect those of the United States Government or any agency thereof. 


\section{DISCLAIMER}

Portions of this document may be illegible in electronic image products. Images are produced from the best available original document. 


\section{Preface}

Decommissioning of U.S. Uranium Production Facilities analyzes the decommissioning process ${ }^{1}$ and its potential impact on uranium supply and prices. As early as the 1960 's, public pressure arose to impose additional control measures to govern the disposal of uranium waste materials. Although the environmental and financial implications of decommissioning uranium production facilities continue to attract widespread interest, very few data have been compiled on the subject and even fewer have been published. In 1993, the Energy Information Administration produced its first publication on this subject. ${ }^{2}$

Section 205(a)(2) of the Department of Energy Organization Act of 1977 (Public Law 95-91) requires the Administrator of the Energy Information Administration (EIA) to carry out a central, comprehensive, and unified energy data information program that will collect, evaluate, assemble, analyze, and disseminate data and information relevant to energy resources, reserves, production, demand, technology, and related economic and statistical information.

To assist in meeting these responsibilities in the area of nuclear fuels, the EIA has prepared this report, Decommissioning of U.S. Uranium Production Facilities. Because there are many issues associated with decommissioning-environmental, political, and financial-this report will concentrate on the answers to three questions: (1) What is required? (2) How is the process implemented? (3) What are the costs? This report consolidates information on the current status of decommissioning of uranium producing facilities in the United States, and analyzes some of the implications of the regulatory requirements, site remediation process, and costs of plant dismantling, tailings reclamation, groundwater restoration, and long-term monitoring of the site.

Chapter 1 describes the growth of the domestic uranium industry and the development of the regulatory framework. Initially, few regulations were imposed on the mining and processing of ores, and there were no unique regulations for radioactive ores. The current regulations reflect the evolving role of Government agencies and industry in assessing uranium wastes and establishing control measures. The roles of the U.S. Nuclear Regulatory Commission (NRC) and the U.S. Environmental Protection Agency (EPA) are described.

Chapter 2 provides a general description of production methods, current status, and the types of wastes cleanup problems as well as reclamation processes followed at conventional uranium production facilities. The decommissioning plan for the Homestake Mining Company's Grants production facility, described in detail in this chapter, illustrates the specific environmental remediation procedures involved. The chapter concludes with an analysis of decommissioning costs at 19 conventional production facilities.

Chapter 3 describes the decommissioning procedures at nonconventional production facilities. The decommissioning procedures at conventional and nonconventional operations are similar in many ways, but there are also many differences. This chapter highlights the decommissioning activities at in situ leaching processing plants and wellfields, and reviews a typical in situ operation's decommissioning plan. The chapter concludes with an analytical comparison of decommissioning costs for 14 in situ leaching projects.

The report concludes by focusing on the potential impact of decommissioning costs on current and future uranium supply.

This report focuses strictly on the decommissioning of the uranium production facilities covered by Title II of the Uranium Mill Tailings Radiation Control Act of 1978 (P.L. 95-604). These facilities serve a commercial market; however, some of them also processed uranium for the Federal Government. ${ }^{3}$

\footnotetext{
${ }^{1}$ Decommissioning is a general term covering various activities. For conventional facilities, it includes decontamination and dismantling of the mill, site restoration (including groundwater cleanup), reclamation of mill tailings, and long-term monitoring of the site. Decommissioning nonconventional in situ leaching facilities includes decontaminating, dismantling, and removing plant facilities and wellfield equipment, site reclamation, groundwater restoration, and long-term monitoring of the site.

2"Decommissioning of U.S. Conventional Uranium Production Centers," Uranium Industry Annual 1992, Washington, DCC(October 1993).

${ }^{3}$ Mills designated as "Title I" mills were operated for the U.S. Atomic Energy Commission (AEC), the predecessor agency of the Department of Energy (DOE), to supply the uranium requirements of the Federal Government. The DOE is in the process of decommissioning these facilities with the objective of cleaning up "the current waste inventory within the DOE nuclear complex by the year 2019." More detail on this subject can be found in the U.S. Department of Energy report, Integrated Data Base for 1993: U.S. Spent Fuel and Radioactive Waste Inventories, Projections and Characteristics, March 1994, DOE/RW-0006, Rev. 9, Washington, DC.
} 


\section{Contents}

Executive Summary $\ldots \ldots \ldots \ldots \ldots \ldots \ldots \ldots \ldots \ldots \ldots \ldots \ldots \ldots \ldots \ldots \ldots \ldots \ldots \ldots \ldots \ldots \ldots$

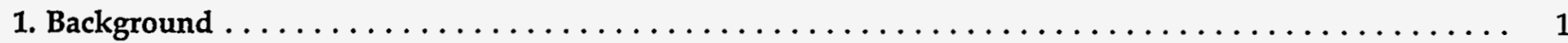

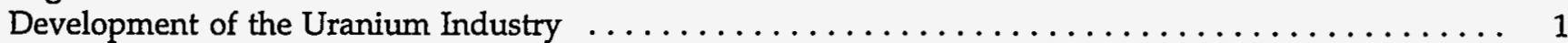

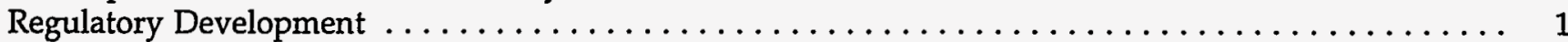

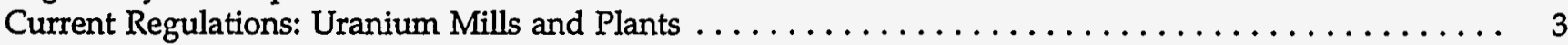

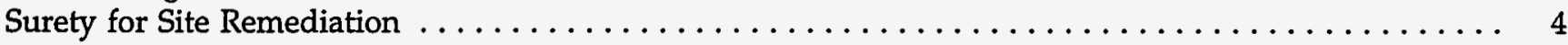

Current Regulations: Uranium Mines $\ldots \ldots \ldots \ldots \ldots \ldots \ldots \ldots \ldots \ldots \ldots \ldots \ldots \ldots \ldots \ldots \ldots .4$

2. Decommissioning of Conventional Uranium Production Facilities $\ldots \ldots \ldots \ldots \ldots \ldots \ldots \ldots \ldots \ldots$

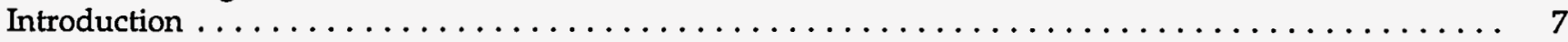

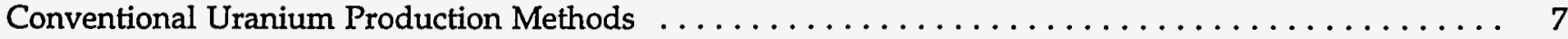

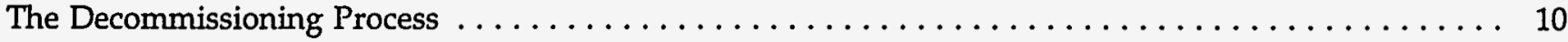

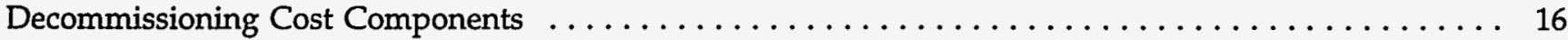

3. Decommissioning of Nonconventional (In Situ Leach) Production Facilities . . . . . . . . . . . . 29

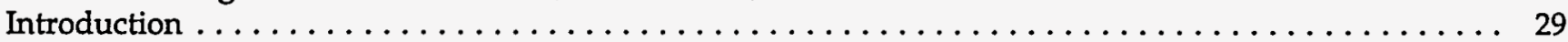

Nonconventional Uranium Production Methods $\ldots \ldots \ldots \ldots \ldots \ldots \ldots \ldots \ldots \ldots \ldots \ldots \ldots \ldots \ldots$

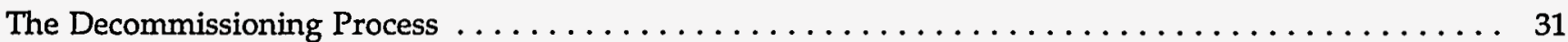

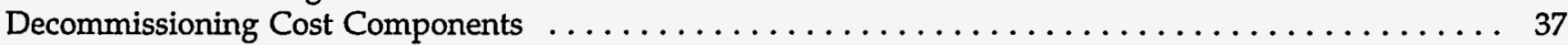

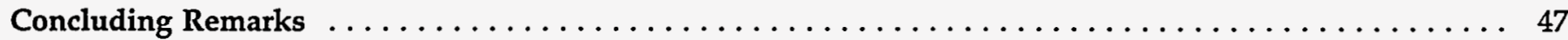

Appendices

A. Criteria of the NRC Performance Objectives on Mill Tailings Reclamation . . . . . . . . . .. 49

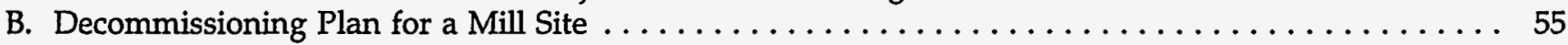

C. Decommissioning Plan for an In Situ Leaching Site $\ldots \ldots \ldots \ldots \ldots \ldots \ldots \ldots \ldots \ldots \ldots \ldots$

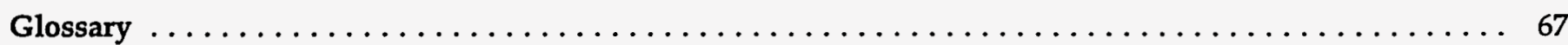


1. Status of Conventional U.S. Uranium Production Facilities as of January $1,1994 \ldots \ldots \ldots \ldots \ldots$

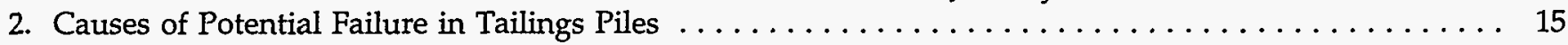

3. Estimated Decommissioning Costs for Conventional Uranium Production Facilities as of

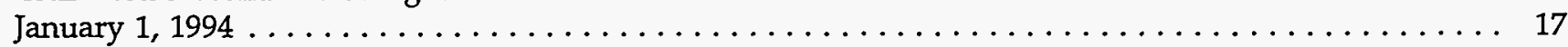

4. Mill Tailings Reclamation Summary as of January $1,1994 \ldots \ldots \ldots \ldots \ldots \ldots \ldots \ldots \ldots \ldots$

5. Status of Nonconventional Uranium Production Facilities as of January $1,1994 \ldots \ldots \ldots \ldots$. . . . . 29

6. Estimated Decommissioning Costs for U.S. Nonconventional Uranium Production Facilities as of

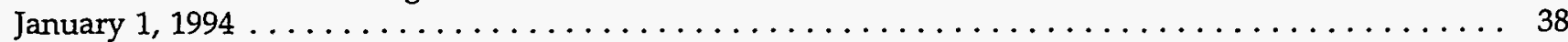

7. Estimated Wellfield Restoration Costs for U.S. Nonconventional Uranium Production Facilities

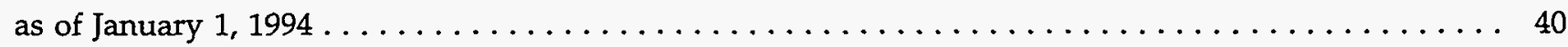

8. Estimated Groundwater Restoration Costs for U.S. Nonconventional Uranium Production Facilities as of

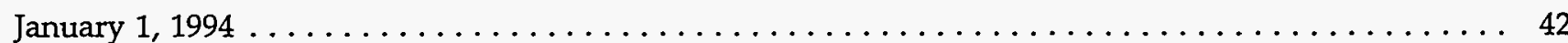

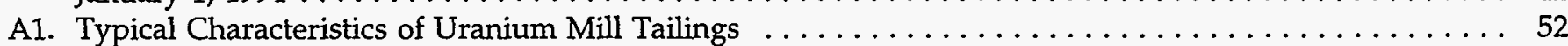

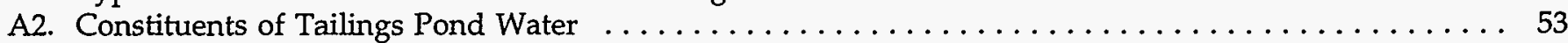

B1. Distribution of Decommissioning Cost Components for a Conventional Mill . . . . . . . . . . 58

C1. Distribution of Decommissioning Cost Components for a Nonconventional Production Facility . . . ... 64

\section{Figures}

1. Location and Status of U.S. Uranium Mills and Plants as of January $1,1994 \ldots \ldots \ldots \ldots \ldots \ldots$

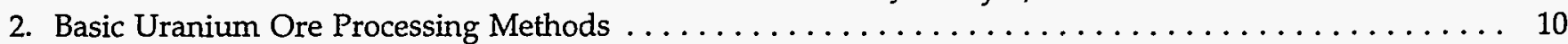

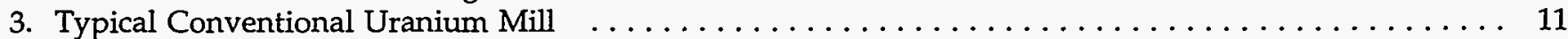

4. Conventional Production Facility Remediation Scheme $\ldots \ldots \ldots \ldots \ldots \ldots \ldots \ldots \ldots \ldots \ldots \ldots \ldots$

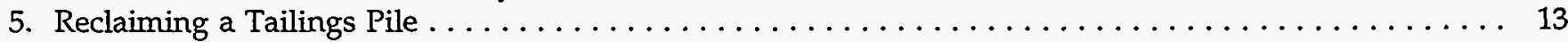

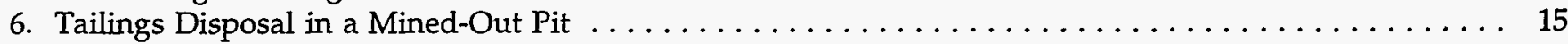

7. Estimated Total Decommissioning Costs for Conventional Facilities as of January 1, $1994 \ldots \ldots \ldots$

8. Major Components of Estimated Decommissioning Costs for Conventional Facilities as of

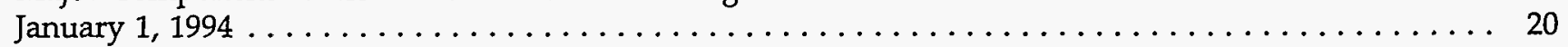

9. Uranium In Situ Leach Process . . . . . . . . . . . . . . . . . . . . . . . . . . . 31

10. Nonconventional Production Facility Remediation Scheme $\ldots \ldots \ldots \ldots \ldots \ldots \ldots \ldots \ldots \ldots \ldots \ldots . \ldots \ldots$

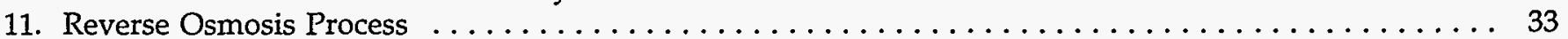

12. Groundwater Sweep Process . . . . . . . . . . . . . . . . . . . . . . . 34

13. Estimated Total Decommissioning Costs for Nonconventional Facilities as of January 1, 1994 . . . . . 39

14. Major Components of Estimated Decommissioning Costs for Nonconventional Facilities as of

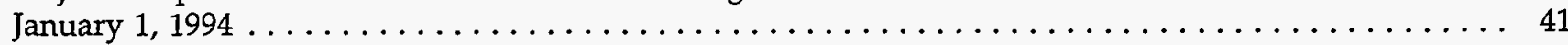




\section{Executive Summary}

From 1980 to 1993 , the domestic production of uranium declined from almost 44 million pounds $\mathrm{U}_{3} \mathrm{O}_{8}$ to about 3 million pounds. ${ }^{4}$ This retrenchment of the U.S. uranium industry resulted in the permanent closing of many uranium-producing facilities. Current low uranium prices, excess world supply, and low expectations for future uranium demand indicate that it is unlikely existing plants will be reopened. Because of this situation, these facilities eventually will have to be decommissioned. ${ }^{5}$

The Uranium Mill Tailings and Radiation Control Act of 1978 (UMTRCA) vests the U.S. Environmental Protection Agency (EPA) with overall responsibility for establishing environmental standards for decommissioning of uranium production facilities. UMTRCA also gave the U.S. Nuclear Regulatory Commission (NRC) the responsibility for licensing and regulating uranium production and related activities, including decommissioning. ${ }^{6}$ Because there are many issues associated with decommissioning-environmental, political, and financial-this report will concentrate on the answers to three questions: (1) What is required? (2) How is the process implemented? (3) What are the costs?

Regulatory control is exercised principally through the NRC licensing process. Before receiving a license to construct and operate an uranium producing facility, the applicant is required to present a decommissioning plan to the NRC. Once the plan is approved, the licensee must post a surety to guarantee that funds will be available to execute the plan and reclaim the site. (The surety must also include funds necessary for longterm monitoring of the decommissioned site that becomes the responsibility of the U.S. Department of Energy or the appropriate State agency.)

Although the environmental and financial implications of decommissioning uranium production facilities have attracted widespread interest, few data have been compiled on the subject and even fewer have been pub- lished. This report by the Energy Information Administration (EIA) represents the most comprehensive study on this topic by analyzing data on 33 (out of 43) uranium production facilities. These facilities are located in Colorado, Nebraska, New Mexico, South Dakota, Texas, Utah, and Washington.

The decommissioning process and associated costs are analyzed for both conventional and nonconventional (in situ leaching) facilities. Conventional operations excavate uranium ore by open pit or underground mining. The uranium is then recovered from the ore at a processing mill. The waste material (tailings) from the mill is then sent to a tailings pile. In situ leaching operations utilize a series of wells rather than mines to recover the uranium from the ground.

On average, tailings reclamation activities account for approximately 54 percent of the decommissioning costs for conventional uranium mills. Average decommissioning costs for a conventional production facility are $\$ 14.1$ million: $\$ 7.7$ million for tailings reclamation, $\$ 2.3$ million for groundwater restoration, and $\$ 0.9$ million for mill dismantling and $\$ 3.2$ million for indirect costs (Figure ES1).

Because nonconventional (in situ leaching) operations do not require removal of ore to the surface, there are no mill tailings and surface disturbance is kept to a minimum. Groundwater restoration accounts for the largest share of decommissioning costs ( 40 percent of the total) at nonconventional operations. Of the estimated \$7 million average decommissioning cost for nonconventional sites, groundwater restoration accounted for $\$ 2.8$ million (Figure ES2). The wellfield reclamation costs were $\$ 0.9$ million and the plant dismantling costs came to $\$ 0.6$ million. Other costs (such as evaporation ponds, disposal wells, and radiological surveys) averaged $\$ 1.2$ million. The indirect costs averaged $\$ 1.4$ million.

\footnotetext{
${ }^{4}$ Energy Information Administration, Uranium Industry Annual 1993, DOE/EIA-0478(93) (Washington, DC, September 1994).

${ }^{5}$ Decommissioning is a general term covering various activities. For conventional facilities, it includes decontamination and dismantling of the mill, site restoration (including groundwater cleanup), reclamation of mill tailings, and long-term monitoring of the site. Decommissioning of nonconventional in situ leaching facilities includes decontaminating, dismantling, and removing plant facilities and wellfield equipment, site reclamation, groundwater restoration, and long-term monitoring of the site.

${ }^{6}$ Three States-Colorado, Texas, and Washington-conduct their own regulatory programs, which are subject to the NRC's review.
} 
Figure ES1. Estimated Average Decommissioning Costs, U.S. Conventional Uranium Production Facilities

Distribution of Costs, by Component

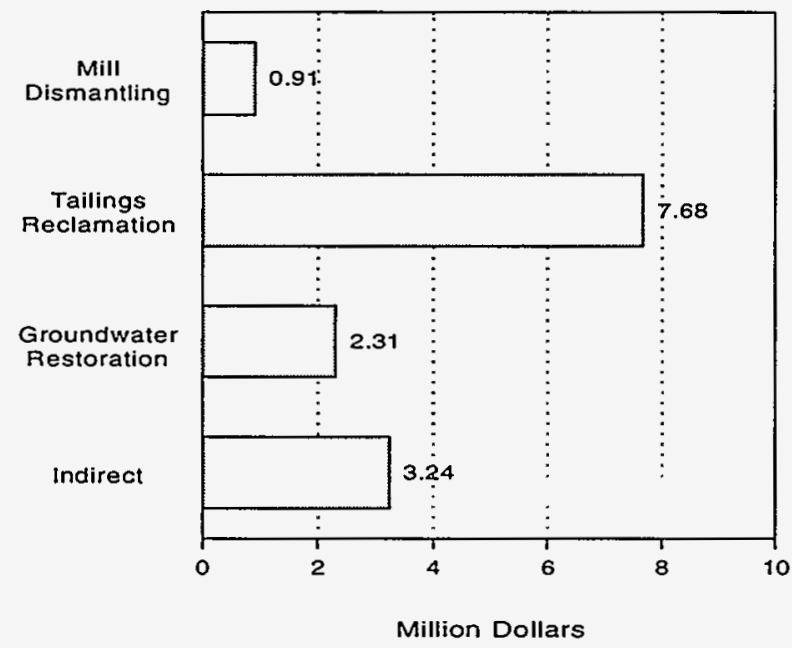

Source: Cost estimates are based on data from the U.S. Nuclear Regulatory Commission, State agencies, or companies.

The reader should take care to consider the results in context. Although sufficient data were obtained to analyze 80 percent of the uranium facilities identified in the study, the total number of production facilities is small, placing limits on an effective statistical analysis. In addition, cost data in this report are estimates. Actual costs are not readily available, because decommissioning activities, especially groundwater restoration, take years. The report confirms some general trends, but the "exceptions" take on greater significance in a small sample, and may indicate unanticipated problems that could be encountered at any site.
Figure ES2. Estimated Average Decommissioning Costs, U.S. Nonconventional Uranium Production Facilities

Distribution of Costs, by Component

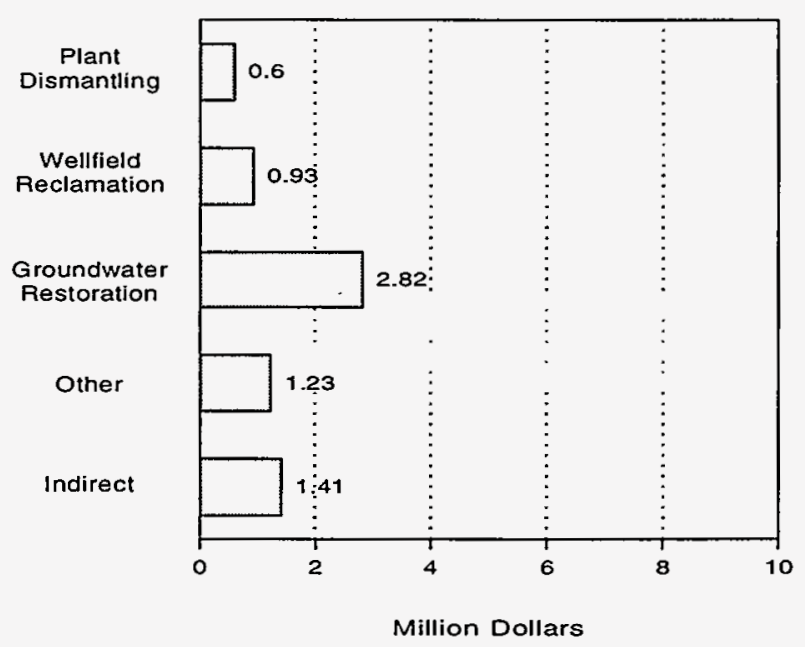

Source: Cost estimates are based on data from the U.S. Nuclear Regulatory Commission, State agencies, or companies.

Although decommissioning costs are expected to continue to have an influence on future operations, improved designs for newer plants and tailings piles are expected to reduce their impact. Decommissioning costs are factored into future uranium prices, and the impact on production should be relatively minor, largely because other pertinent criteria-such as acquisition, exploration, development, and operating costs and market conditions-will be more influential in production decisions. 


\section{Background}

\section{Development of the Uranium Industry}

The exploration and mining of radioactive ores in the United States began around the turn of the century. Sources for radium (contained in uranium ore) were being sought for use as luminous paint for watch dials and other instruments and for research for other possible uses. Mines in the Uravan Mineral Belt of western Colorado and eastern Utah produced small quantities of high-grade radium ore from outcrops of shallow deposits in the Salt Wash Member of the Morrison Formation. The ores were primarily carnotite; that is, bright yellow bimetal ores (uranium and vanadium oxide) that occur with organic debris in sandstones.

By the 1920's, the demand for vanadium to produce steel alloys led to an increase in the mining and processing of carnotite ores. The uranium itself, being of little value at the time, was usually discarded during the process of recovering the vanadium. Demand for vanadium continued to increase, particularly with the entry of the United States into World War II, which further stimulated mining of newly discovered deposits.

Uranium became important during the war. In 1943, the Union Mines Development Corporation, assisted by the U.S. Government, operated mills in Colorado to process uranium ore for the Manhattan Project, which applied atomic power to military use. In the postwar years, uranium continued to be essential to the national defense. Because of this, Congress passed the Atomic Energy Act of 1946, creating the U.S. Atomic Energy Commission (AEC). The Commission launched a uranium procurement program that encouraged exploration, primarily in the Colorado Plateau region, which includes parts of Colorado, Utah, Arizona, and New Mexico. Gradually, new uranium deposits were discovered in these States as well as in Wyoming, Texas, South Dakota, and Washington (Figure 1). With the discovery of these significant deposits (primarily uraninite and coffinite), expansive mining and milling facilities were constructed, and new and improved processing methods were developed.
The AEC laid the foundation for the work of the uranium industry and trained many uranium experts. It performed research, provided technical assistance to industry in exploring, mining, and milling uranium, encouraged property development and uranium marketing, and secured sufficient uranium stockpiles to meet defense requirements well into the future. During the Agency's tenure, the uranium industry significantly improved its techniques for recovering and processing radioactive ores.

Between the mid-1940's and the mid-1960's, uranium was used almost exclusively for military purposes, and only the Federal Government owned significant quantities of uranium in the United States. Military requirements gradually declined during the 1960 's, and the Government completed its uranium procurement program by the end of 1970 . Simultaneously, a major new source of demand emerged-commercial nuclear power plants. The commercial use of uranium for electricity generation was further encouraged by the passage of the Private Ownership of Special Nuclear Materials Act in 1964, which ended the Federal Government's monopsony position in the domestic uranium market.

\section{Regulatory Development}

Initially, the Government regarded the mining and milling of radioactive ores as it did any other mining activity, imposing few regulations. There were no special regulations, for radioactive ores, nor were there many Government guidelines or directives for siting plants or discharging tailings. ${ }^{1}$

With America's entry into World War $\Pi$, the Government assumed a much more active role in the uranium industry. Federal contracts for purchasing uranium concentrate to support defense programs were initiated by the U.S. Army's Manhattan Engineering District from 1942 to 1946 and by the AEC from 1947 to 1970. The Atomic Energy Act of 1946 (superseded by the Atomic Energy Act of 1954, as amended) invested the

${ }^{1}$ For a definition of tailings, see the Glossary. 
Figure 1. Location and Status of U.S. Uranium Mills and Plants as of January 1, 1994

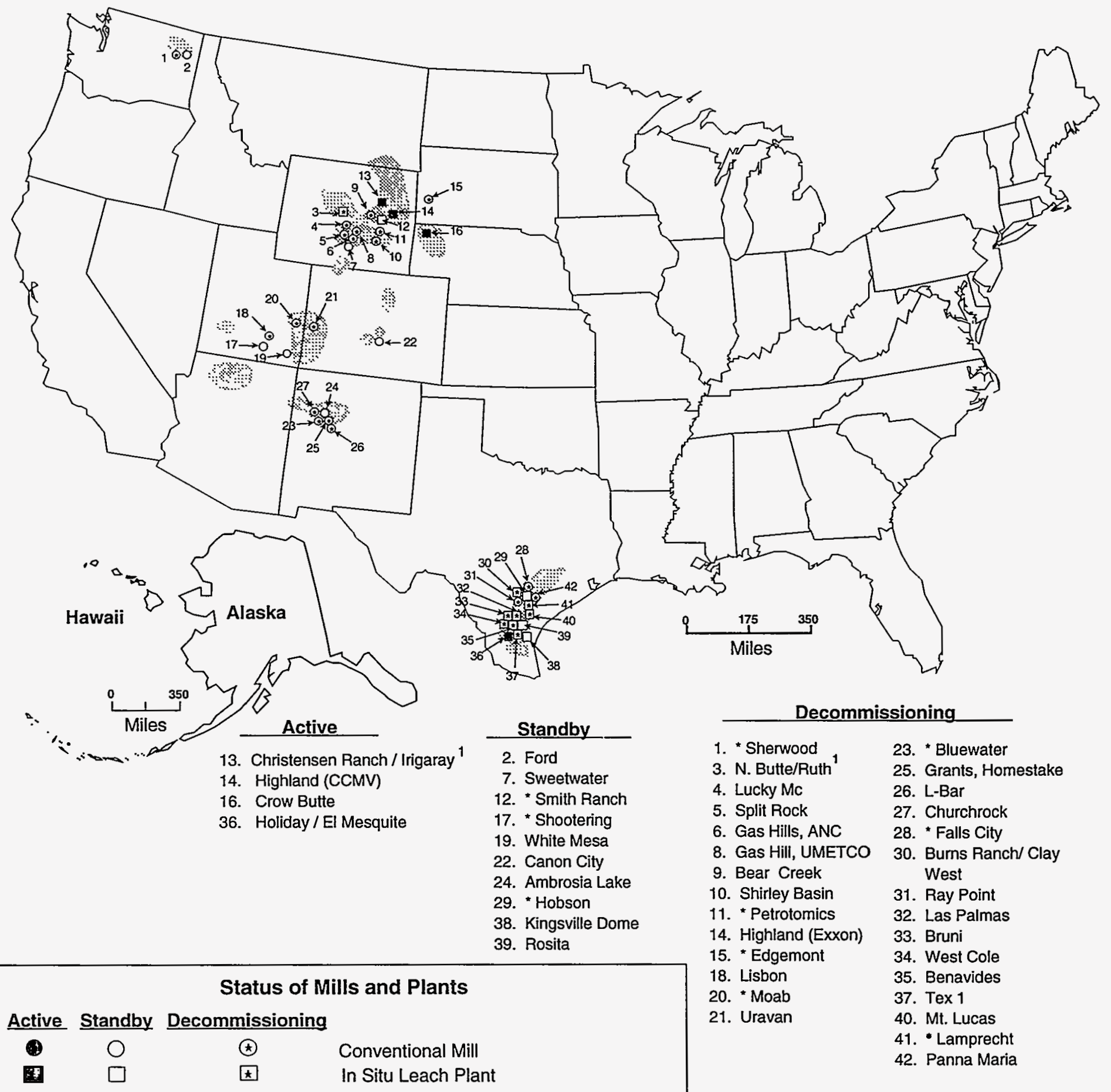

Major Uranium Reserve Areas

- Cost data not included in this report

${ }^{1} \mathrm{NRC}$ regards as a single entity.

Note: Highland (14) is the site for both a decommissioned conventional mill and an active nonconventional facility.

Source: Based on U.S. Department of Energy, Grand Junction Project Office (GJPO), National Uranium Resource Evaluation, Interim Report (June 1979) Figure 3.2; GJPO data files; Energy Information Administration, Form ElA-858, "Uranium Industry Annual Survey" (1993). 


\section{Regulatory Development}

1946 - Atomic Energy Act
1954 - Atomic Energy Act, as amended
1964 - $\begin{aligned} & \text { Private Ownership of Special Nuclear } \\ & \text { Materials Act }\end{aligned}$
1974 - Energy Reorganization Act
1978 - Uranium Mill Tailings Radiation Control
Act (UMTRCA)
1992 - The Energy Policy Act, Title X,
Remedial Action and Uranium Revital-
ization

AEC with regulatory authority over radioactive materials.

The AEC, however, interpreted its authority as beginning after ores were removed from the minesessentially, when the ores were received at ore processing mills. But even the AEC's regulatory influence over mills was hindered by the absence of a clear definition of the role of State agencies. Such ambiguity minimized regulatory control on site selection, operation, design, construction, and decommissioning of mills.

Tailings discharges in rivers, the vulnerability of storage sites to wind erosion, and the possibility of contaminated debris from construction sites increased public pressure for additional control and remedial actions. During the 1960's and early 1970's, growing uncertainty about the adequacy of regulations governing disposal of uranium waste materials led to additional control measures.

The first remedial action program related to uranium mill tailings was authorized by the Atomic Energy Commission Appropriations Act (Public Law 92-314) on June 16, 1972. This program provided for remedial action for properties in the vicinity of Grand Junction, Colorado (under the Title I program of the Uranium Mill Tailings Radiation Control Act), where there were an estimated 300,000 tons of tailings sands that building contractors and individuals had used as construction or fill material. ${ }^{2}$
In 1975, in accordance with the Energy Reorganization Act of 1974 (Public Law 93-438), the AEC was divided into two separate agencies: the Energy Research and Development Administration-which later was combined with the Federal Energy Administration into the U.S. Department of Energy (DOE)-and the U.S. Nuclear Regulatory Commission (NRC). Primary responsibility for regulating uranium processing and decommissioning activities was transferred from the AEC to the NRC, which was given authority over the licensing process for uranium production facilities and authorized to provide further direction through rulemaking procedures, Federal Register notices, guideline documents, and workshops. Three States-Colorado, Texas, and Washington-elected to operate their own programs for regulating uranium production facilities. Under agreement with the NRC, however, all regulations adopted must conform to those of the NRC. The $\mathrm{NRC}$ is authorized to review all regulations.

\section{Current Regulations: Uranium Mills and Plants}

In November 1978, the Congress enacted Public Law 95-604, the Uranium Mill Tailings Radiation Control Act (UMTRCA), which provides for the cleanup and stabilization of uranium mill tailings at currently inactive uranium processing sites. UMTRCA vests the U.S. Environmental Protection Agency (EPA) with the overall responsibility for establishing environmental standards and guidelines, but regulatory responsibilities for U.S. nuclear facilities, including uranium mills, remain with the NRC. UMTRCA is the basis for present-day control of uranium mill sites.

Uranium production facilities may be categorized as Title I or Title II facilities based on this legislation. This report focuses strictly on the decommissioning of the uranium production facilities covered by Title II of the Uranium Mill Tailings Radiation Control Act of 1978 (P.L. 95-604). These facilities serve a commercial market; however, some of them also processed uranium for the Federal Government.

Applicable EPA standards under UMTRCA are contained in the Code of Federal Regulations, 40 CFR Part 192, "Health and Environmental Protection Standards

${ }^{2}$ Mills designated as "Title I" mills were operated for the U.S. Atomic Energy Commission (AEC), the predecessor agency of the Department of Energy (DOE), to supply the uranium requirements of the Federal Government. The DOE is in the process of decommissioning these facilities with the objective of cleaning up "the current waste inventory within the DOE nuclear complex by the year 2019." More detail on this subject can be found in the U.S. Department of Energy report, Integrated Data Base for 1993: U.S. Spent Fuel and Radioactive Waste Inventories, Projections and Characteristics, March 1994, DOE/RW-0006, Rev. 9, Washington, DC. 
for Uranium and Uranium Mill Tailings." Issuing an operating license and enforcing the regulations, however, are NRC responsibilities under 10 CFR Part 40, "Domestic Licensing of Source Material." ${ }^{\text {"3 }}$ The legislation requires that each NRC license contain provisions regarding decontaminating, decommissioning, and reclaiming the licensed facility.

As part of the licensing requirements, each applicant must submit to the NRC or to the "agreement" State ${ }^{4}$ a detailed study called the Generic Environmental Impact Statement (GEIS), which reviews all aspects of the construction of the uranium production facility and provides various approaches to reclaiming the site and its uranium tailings. The final GEIS must be approved by the NRC or the "agreement" State on granting a license.

The license issued to the operator of a uranium production facility sets forth the conditions for operation and actions that the licensee must take for decommissioning. A licensee must present a plan for site reclamation to the NRC or the appropriate State for approval. The NRC or the State and the licensee must agree on the estimated costs for the work to be done, assuming that a third party might be required to do the work. If the NRC or the State approves the plan and the cost estimate, the licensee must then provide a surety to assure that funds will be available to reclaim the site if the licensee is unable to complete the task. The cost estimate and surety must also include the funds necessary for the long-term surveillance and monitoring of the decommissioned site to protect public health and safety. After satisfactory completion of decommissioning by the licensee, title to the site and the uranium tailings passes to the DOE (or the appropriate State), which is responsible for long-term monitoring and care of the site.

Recently, Title X of the Energy Policy Act of 1992 (Public Law 102-486) established a new responsibility for the DOE, which is now required to reimburse licensees of active uranium or thorium processing sites for remedial action costs attributable to byproduct material (mill tailings) generated as an incidence of uranium or thorium concentrate sales to the United States. Specifically, DOE is mandated to reimburse qualified licensees up to $\$ 5.50$ per dry short ton of Federally-related tailings. ${ }^{5}$ Total reimbursement for all uranium licensees combined is limited to $\$ 270$ million, and maximum reimbursement to the single eligible thorium licensee is limited to $\$ 40$ million.

\section{Surety for Site Remediation}

Licenses issued by the NRC or the "agreement" States to operators of uranium production facilities set forth the conditions for operation. The licensee must complete site remediation to standards established by Federal and State regulators. Licensees are required to provide surety. Surety (in the form of cash, tangible assets, or both) must be kept in place until the responsible agencies have approved a release stating that the licensee has completed restoration and reclamation to the acceptable standard in accordance with the UMTRCA requirements. Surety must be set at a sufficient amount to cover the cost of the work to be done, with the assumption that a third party might be required to do the work if the licensee is unable to complete the task. The licensing authorities review and reevaluate the surety coverage as time progresses.

Surety is posted to encompass a number of activities, including plant decommissioning, tailings reclamation, groundwater restoration, wellfield closure, surface decontamination, revegetation, and long-term monitoring. Any contaminated equipment, structures, or pipes must be crushed and disposed of, along with contaminated soil residues, in a licensed disposal area where long-term monitoring will be assured. Therefore, the cost estimate and surety must include a fee set by the NRC or the "agreement" State for funds necessary for the long-term surveillance and monitoring of the site to protect public health and safety.

At present, the uranium industry has committed over $\$ 300$ million to surety. Surety does not increase the operating cost of uranium mining and processing, but it does increase the amount of capital employed by the industry and does impose financial costs. Surety is reassessed annually to accommodate inflation and to take into account decommissioning work completed.

\section{Current Regulations: Uranium Mines}

Like the AEC before it, the NRC does not interpret its authority as extending to uranium underground or open pit mines. Likewise, the Office of Surface Mining Reclamation and Enforcement, U.S. Department of the Interior, excludes itself from the regulation of uranium mines. Instead, the Office's programs are concerned solely with coal mines. The enforcement of most mining regulations is carried out by the individual States. With

\footnotetext{
${ }^{3}$ The specific criteria set forth in detail in Appendix A of UMTRCA and are summarized in Appendix A of this report.

${ }^{4} \mathrm{New}$ Mexico was originally an "agreement" State, but later rescinded.

${ }^{5}$ For a definition of Federally related tailings, see the Glossary.
} 
their significant mineral and coal resources, Colorado and Wyoming have active mining programs. For example, State laws in Wyoming have been effective in encouraging phased open pit operations and associated reclamation activities. Colorado also has an abandoned mines law and a fund for reclamation work. However, the funds are derived from coal companies, and most of the reclamation effort has been on coal mines and on metal mines (other than uranium mines.)

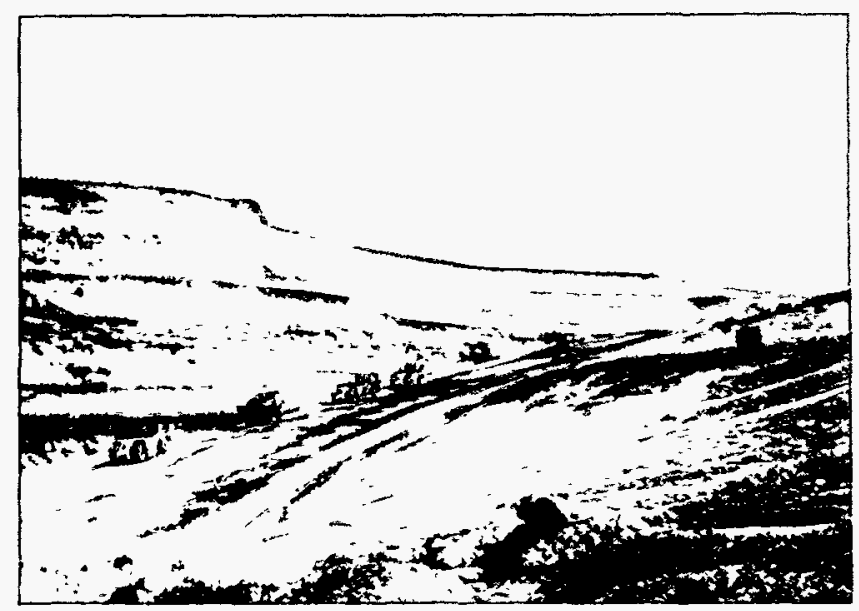

Chevron's Panna Maria uranium open pit mine in Kames County, Texas.

Mines on Federal land may be subject to Bureau of Land Management (BLM), Department of the Interior, requirements or to requirements specified in lease terms, such as those applicable to Indian mineral lease lands. The Federal Land Policy and Management Act of 1976 (Public Law 94-579) provides the basis for BLM control of mining lands. Regulations are set forth in 43 CFR Part 3809, "Surface Management." These regulations primarily affect disturbances of over 5 acres. Their objective is to protect Federal lands from degradation.
Larger operations require an approved operating plan, but existing mines can continue to operate while approved plans are being developed. The regulations are general in scope and do not preempt State laws regarding mining properties. Implementation of the State and BLM regulations can be worked out, as in Wyoming, through agreements between the State and the BLM. Some uranium mines, however, predate the period of mine regulation development and may not be covered.

For surface mines, regardless of type, the principal environmental concerns involve excavations and waste piles. Such mines may have to be backfilled, or pit walls may have to be reshaped to eliminate steep highwalls, to recontour waste piles to a more natural shape, and to allow for revegetation. Other than a mandatory requirement to close shafts and mine openings, underground mines generally have few reclamation requirements.

For open pit uranium mines, reclamation costs can be substantial. For example, the Rocky Mountain Energy Company in Wyoming reportedly spent approximately $\$ 35$ million to backfill pits in the Powder River Basin area. In New Mexico, the large Jackpile and Paguate open pit uranium mines, located on land leased froth the Laguna and Pueblo Indian Tribes, are being reclaimed. ARCO, the company which owned the leases, paid the Laguna and Pueblo Tribes $\$ 45$ million to do the reclamation work, with the agreement that the company would be relieved of further obligations.

Mined area reclamation includes returning the landscape to its original condition. To do this, the overburden must be replaced and recontoured to blend with existing terrain, then covered with original topsoil (which has been stored separately) for reseeding as necessary to establish vegetation. To enhance its longterm survival, the vegetation selected should be indigenous to the area. After satisfactory completion of site remediation by the licensee, the surety is released, and title to the site (including tailings) passes to the $\mathrm{DOE}$ or the appropriate State, which is responsible for long-term monitoring and care of the site. 



\section{Decommissioning of Conventional Uranium Production Facilities}

\section{Introduction}

In the 1980's, demand for U.S. uranium declined significantly, resulting in the need to decommission many production facilities. Information about the decommissioning of these sites provides the basis of this report. Although the procedures for decommissioning a uranium production facility were developed in the 1970 's, sufficient data to analyze the impact of decommissioning on the uranium industry could be obtained only after the closing of a significant number of mills and plants. Acquisition of complete cost data then had to await completion of the decommissioning plan. In fact, the process, especially groundwater restoration, normally requires many years to complete.

To explain the significant issues applicable to the decommissioning process for uranium mill ${ }^{6}$ sites, this chapter discusses: (1) the conventional uranium production methods; (2) the decommissioning process at conventional production facilities; and (3) the cost components for conventional facilities.

The first uranium operations in the United States relied on conventional methods to recover radioactive ore, and for many years this was the only option available. All conventional methods rely on traditional mining although they use various techniques to separate the uranium from the radioactive ore. Nonconventional operations (Chapter 3) rely on alternatives to traditional mining and milling.

There are 26 conventional mill sites in the United States (Table 1). Collectively, these mills had a total capacity of 56,850 tons of ore per day, and they have generated more than 200 million tons of tailings. Decommissioning costs for the conventional production facilities with sufficiently complete data to permit analysis are presented in this report. Data were obtained from the licensees' filings with the NRC. In addition, some estimated cost data were obtained directly from licensees for this report.

\section{Conventional Uranium Production Methods}

To extract the uranium from the ore, conventional operations use either an acid or carbonate (alkaline) leaching method. In the early days, acid leaching was the dominant ore-processing method. Four basic techniques (Figure 2) were employed to separate the minerals from the gangue ${ }^{7}$ and to recover the uranium. Later, for environmental reasons, the carbonate leaching process became more common. However, although carbonate leaching is more environmentally benign than acid leaching, it is generally less efficient in dissolving the uranium.

All operations involving uranium processing produce some form of waste (see box). The amount of waste

\section{Milling Processes and Wastes}

The wastes generated in the milling process include the following:

- Solid wastes consisting mainly of mill tailings from the extraction process, together with contaminated scrap and junk

- Liquid wastes consisting mainly of acidic or neutralized liquors from acid leaching plants or, in the case of alkaline leaching plants, the water used to transport the tailings, plus small volumes of other liquid wastes, such as floor washing and laboratory wastes

- Seepage from waste retention systems

- Decant solution from waste retention systems

- Contaminated runoff from the plant area

- Airborne dusts from conveyor transfer points, tipples, crushing, reagent preparation, and product drying and calcining

- Airborne mists and fumes from reagent preparation and leaching operations.

\footnotetext{
"The terms "uranium mills" and "conventional uranium production facilities" are synonymous. The term "plant" is used in this report to identify a nonconventional, in situ leaching facility (the subject of Chapter 3 ).

${ }^{7}$ For a definition of gangue, see the Glossary.
} 


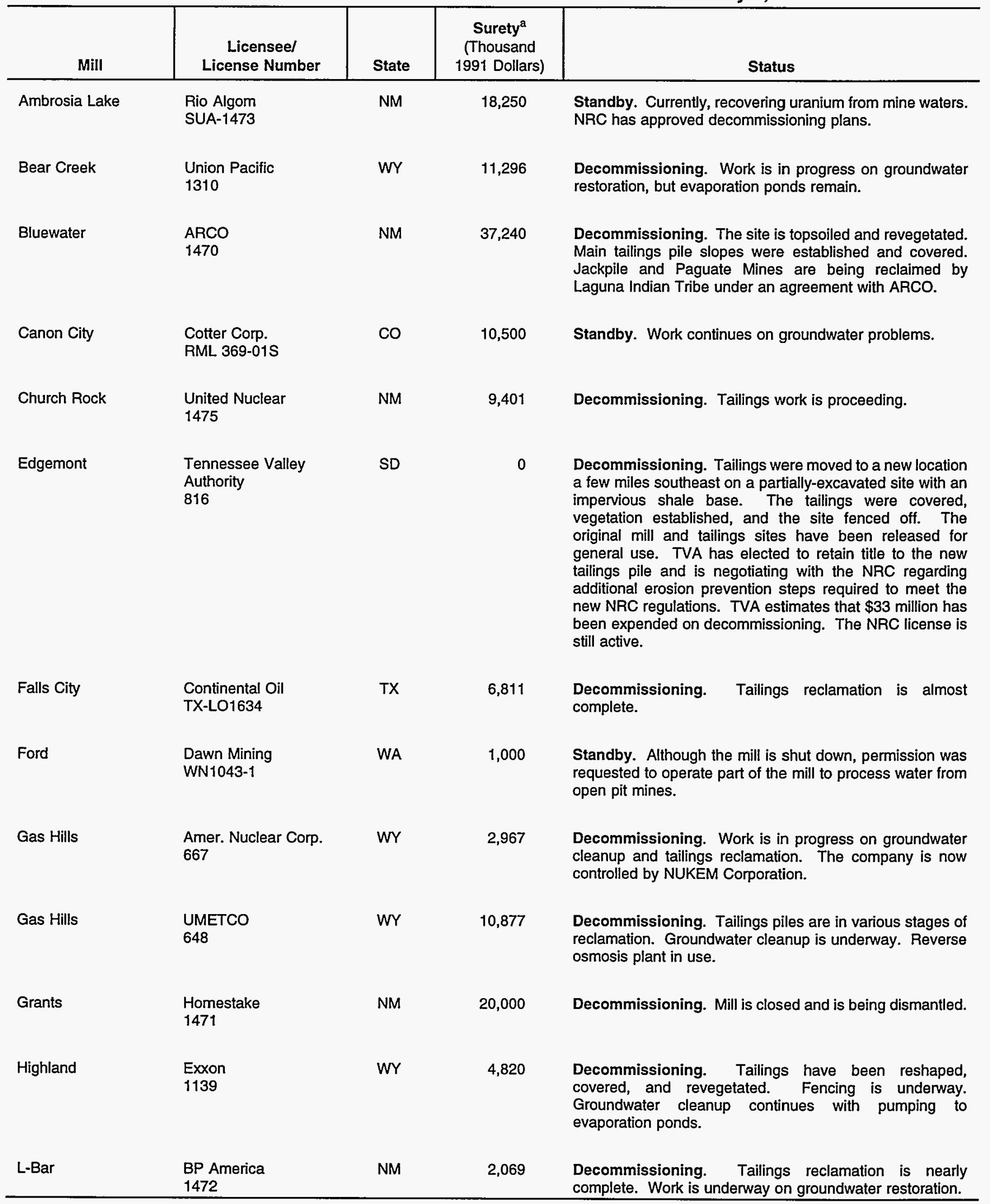

See footnotes at end of table. 
Table 1. Status of U.S. Conventional Uranium Production Facilities as of January 1, 1994 (Continued)

\begin{tabular}{|c|c|c|c|c|}
\hline Mill & $\begin{array}{l}\text { Licensee/ } \\
\text { License Number }\end{array}$ & State & $\begin{array}{l}\text { Surety }^{\mathrm{a}} \\
\text { (Thousand } \\
1991 \text { Dollars) }\end{array}$ & Status \\
\hline Lisbon & $\begin{array}{l}\text { Rio Algom } \\
1119\end{array}$ & UT & 3,467 & $\begin{array}{l}\text { Decommissioning. Plant is closed. Company is negotiating with } \\
\text { NRC on final decommissioning plan. }\end{array}$ \\
\hline Lucky Mc & $\begin{array}{l}\text { Pathfinder Mines } \\
672\end{array}$ & WY & 9,778 & $\begin{array}{l}\text { Decommissioning. Now in the decommissioning phase. Mill is } \\
\text { being dismantled. }\end{array}$ \\
\hline Moab & $\begin{array}{l}\text { Atlas Corp. } \\
\mathbf{9 1 7}\end{array}$ & UT & 6,500 & Decommissioning. Mill is closed and is being dismantled. \\
\hline Panna Maria & $\begin{array}{l}\text { Chevron } \\
\text { TX-LO2402 }\end{array}$ & $\mathrm{TX}$ & 7,145 & $\begin{array}{l}\text { Decommissioning. Mill is closed and is being dismantled. Plant } \\
\text { was sold to General Atomics Corp., but title is still with Chevron. }\end{array}$ \\
\hline Petrotomics & $\begin{array}{l}\text { Petrotomics Company } \\
551\end{array}$ & WY & 5,031 & $\begin{array}{l}\text { Decommissioning. Mill has been dismantled. Tailings } \\
\text { reclamation and groundwater restoration are proceeding. }\end{array}$ \\
\hline Ray Point & $\begin{array}{l}\text { Exxon } \\
\text { TX-LO1431 }\end{array}$ & $\mathrm{TX}$ & 802 & $\begin{array}{l}\text { Decommissioning. Mill has been decommissioned, tailings have } \\
\text { been covered and soil revegetated. Title is still with Exxon. }\end{array}$ \\
\hline Sherwood & $\begin{array}{l}\text { Western Nuclear } \\
\text { WN10133-1 and } \\
\text { WN10133-2 }\end{array}$ & WA & 6,000 & $\begin{array}{l}\text { Decommissioning. Tailings have dried and are being } \\
\text { consolidated. }\end{array}$ \\
\hline Shirley Basin & $\begin{array}{l}\text { Pathfinder Mines } \\
442\end{array}$ & WY & 5,756 & $\begin{array}{l}\text { Decommissioning. Mill was shut down in } 1992 \text { and is being } \\
\text { dismantled. Tailings will be held open for, among other reasons, } \\
\text { accommodating in situ leaching project wastes. }\end{array}$ \\
\hline Shootering & $\begin{array}{l}\text { Plateau Resources } \\
1371\end{array}$ & UT & 2,296 & Standby. Mill is reportedly being offered for sale. \\
\hline Split Rock & $\begin{array}{l}\text { Western Nuclear } \\
056\end{array}$ & WY & 14,000 & $\begin{array}{l}\text { Decommissioning. Company is proceeding to reclaim tailings } \\
\text { and to restore groundwater. }\end{array}$ \\
\hline Sweetwater & $\begin{array}{l}\text { Kennecott } \\
1350\end{array}$ & WY & 4,557 & $\begin{array}{l}\text { Standby. Plant has been sold by Minerals Exploration to the } \\
\text { Green Mountain Mining Venture, with Kennecott Corp. the } \\
\text { operator and licensee of record. Kennecott is a subsidiary of } \\
\text { RTZ Corp. }\end{array}$ \\
\hline Uravan & $\begin{array}{l}\text { UMETCO } \\
660-2\end{array}$ & $\mathrm{co}$ & 30,569 & $\begin{array}{l}\text { Decommissioning. Plant remains, except for some equipment. } \\
\text { The tailings pile(s) have been reshaped and covered. Waste from } \\
\text { the town site is being added to the tailings. New evaporation } \\
\text { ponds are in operation and the older evaporation ponds have } \\
\text { been reclaimed. }\end{array}$ \\
\hline White Mesa & $\begin{array}{l}\text { UMETCO/Energy } \\
\text { Fuels } \\
1358\end{array}$ & UT & 5,473 & $\begin{array}{l}\text { Standby. Tailings reclamation has been concurrent with } \\
\text { operation. }\end{array}$ \\
\hline Total $\ldots$ & $\ldots \ldots \ldots \ldots$ & & 236,605 & \\
\hline
\end{tabular}

aSurety can be a portion of the licensee's assets in lieu of a cash amount.

Source: Company filings with U.S. Nuclear Regulatory Commission or with State authority. Facility names may differ from names in the Integrated Data Base for 1993: "U.S. Spent Fuel and Radioactive Waste Inventories, Projections, and Characteristics." 
Figure 2. Basic Uranium Ore Processing Methods

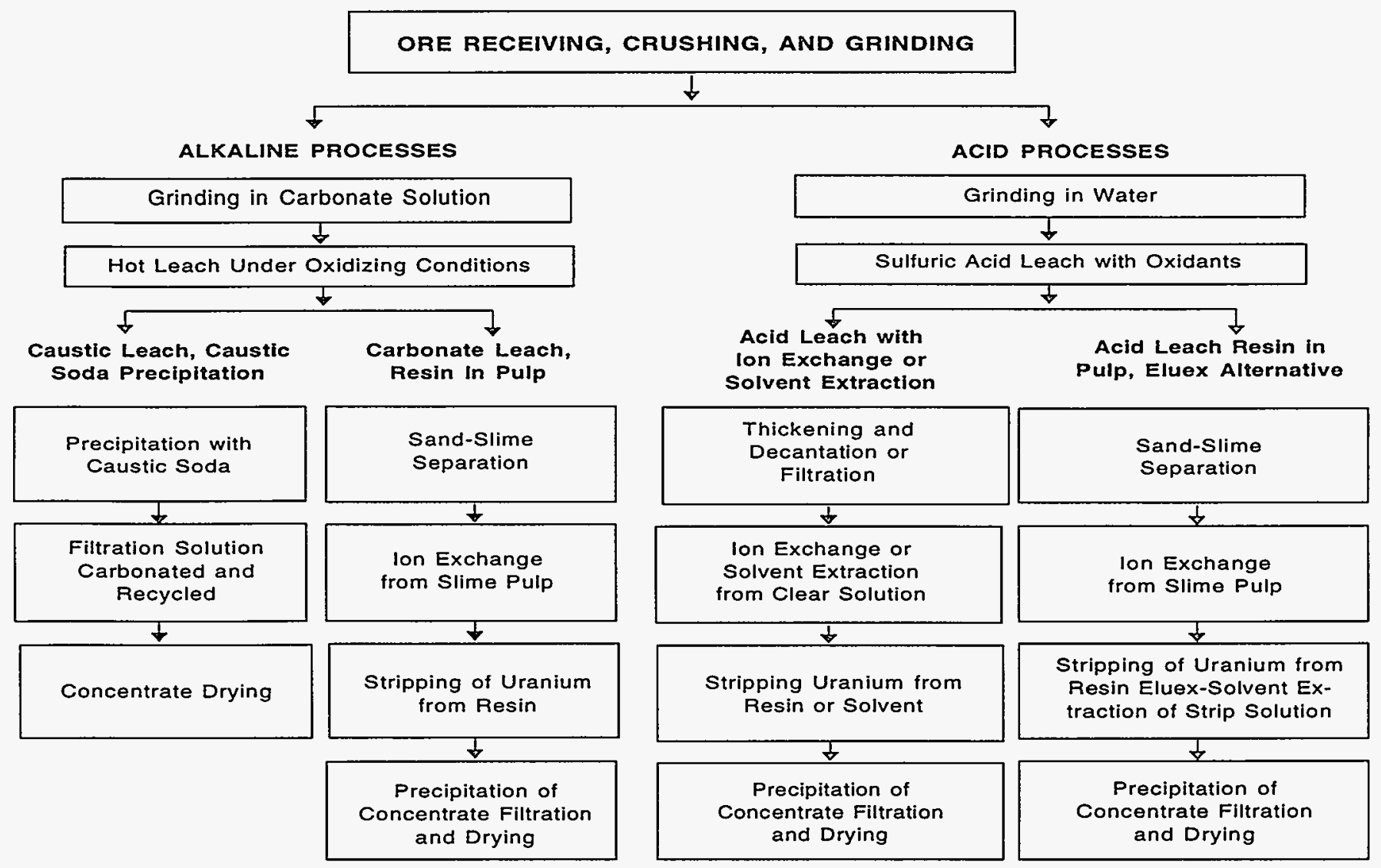

Source: U.S. Atomic Energy Commission, R.H. Kennedy, Ores to Concentrates, a Discussion of the Processing of Uranium Bearing Ores (Washington, DC, 1972).

generated in a typical uranium milling operation (Figure 3) depends on the quantity of mill feed. The mill capacity and total time span during which the mill actually operated can influence the amount of the mill feed.

During processing, the liquid and solid wastes (see box) from the processed ore are sent to the tailings pile. Since only a few pounds of uranium are obtained from a ton of ore, most of the material, including a high percentage of radium, ends up as tailings.

\section{The Decommissioning Process}

The effectiveness of much of the key legislation passed in the late 1970's was frequently tested in the following decade as domestic uranium production fell (from 44 million pounds $\mathrm{U}_{3} \mathrm{O}_{8}$ in 1980 to 3.1 million pounds in
1993), resulting in the permanent closing of a number of uranium-producing facilities and returning the land to other uses. During this period, the uranium industry and the Government acquired experience in the decommissioning of sites, enabling anticipation (and avoidance) of many potential problems.

Decommissioning is a general term encompassing various activities (Figure 4). For companies that employ conventional milling processes, decommissioning involves decontaminating and dismantling the mill itself, reclaiming the tailings pile(s), restoring groundwater to acceptable conditions, and long-term monitoring of the entire process. Radiation levels and the health and safety of workers must be monitored, and records must be maintained to protect the workers and the general public. Access to radiation-contaminated areas and equipment must be controlled. As a result, the decommissioning process is time-consuming and involves significant expense. 


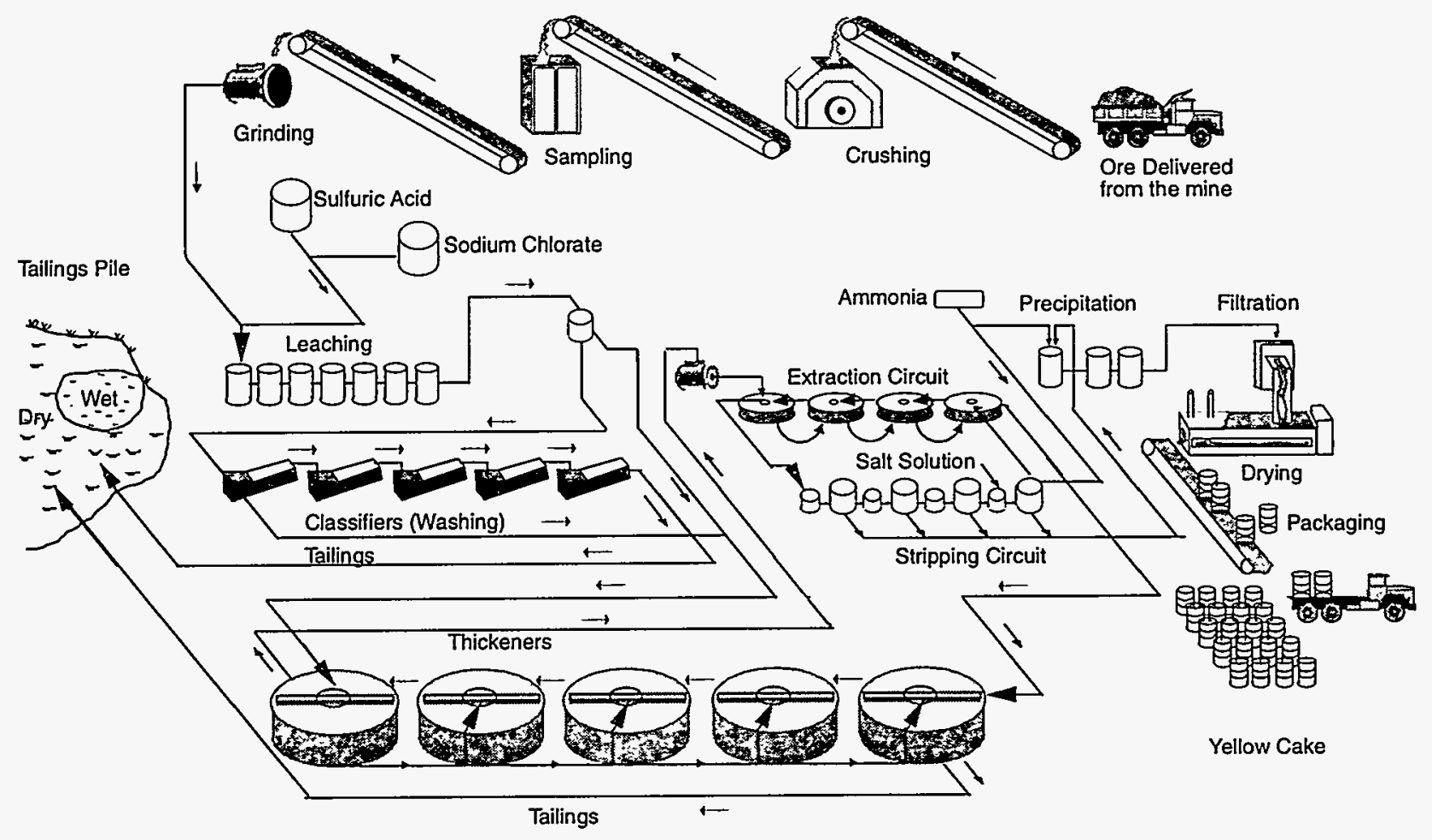

Source: Energy Information Administration, Office of Coal, Nuclear, Electric and Alternate Fuels.

Work on several phases of the decommissioning process, each of which is described in the following sections, can be accomplished simultaneously. For example, the tailings pile can be handled in a phased program of use, stabilization, and reclamation. Also, reclamation work can begin while the mill is still operating.

\section{Mill Decontamination and Dismantling}

The mill decontamination and dismantling activities consist of the following steps:

1. Cleanup and decontamination of equipment and buildings using spraying, steam cleaning, or other methods, as needed for salvage. Also involved in this operation is the disposal of cleanup fluids in evaporation ponds. At some sites, special steps may be required to remove asbestos in the early stages of the cleanup process.

2. Removal of equipment from the buildings during the cleanup process. Equipment is segregated into the following categories: (a) that which is potentially salable for unrestricted use following radiation checks and necessary decontamination, (b) that which is possibly contaminated but potentially salable to other uranium operations, and (c) that which is disposable. Little, if any, equipment is likely to be salvageable. The sales of salvaged equipment are unlikely to be significant, considering the limited potential market, the costs involved for seller and buyer, and the potential liabilities. Salvageable equipment is likely to come from the crushing and grinding sections, where ore is handled before it is contaminated by acid solutions.

3. Dismantling of building and foundation structures. Prior to dismantling, walls and ceilings may require washing or painting to suppress contaminated dust particles.

4. Cutting up larger pieces of equipment and building materials; cutting, crushing, and flattening pipes, tanks, and similar structures for ease of handling. 
Figure 4. Conventional Production Facility Remediation Scheme

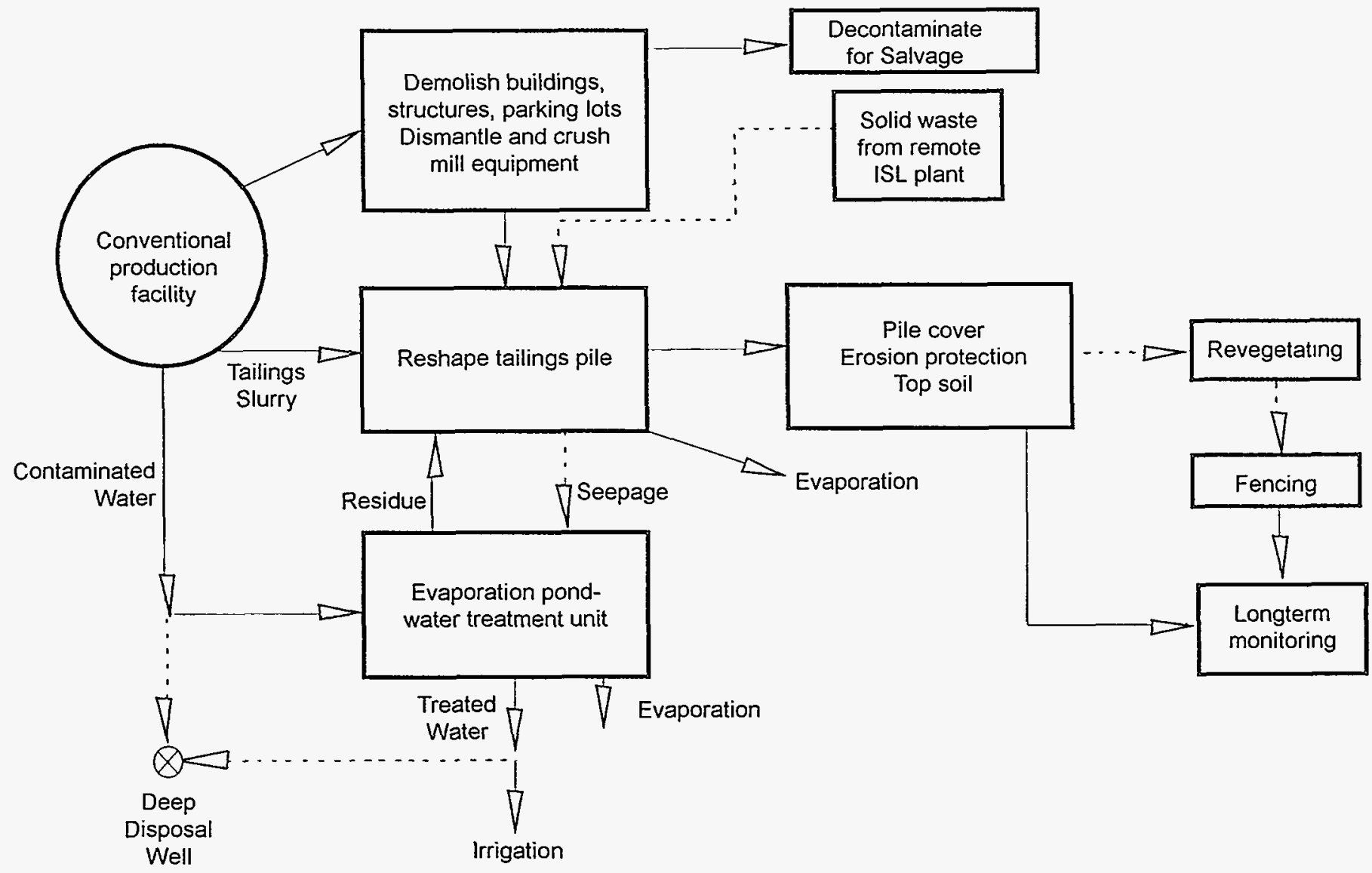

Source: Energy Information Administration, Office of Coal, Nuclear, Electric and Alternate Fuels.

5. Transporting materials and placing them in a burial site, usually in the tailings pile, some distance from the edge of the pile. Material is placed in the pile in layers, which may include solid wastes from remote nonconventional sites, with dirt compacted in and around the material. Since the tailings pile must have dried and compacted sufficiently to support heavy equipment, it might not be accessible for disposal of mill materials for years. Disposal at other locations, however, such as at other tailings piles or specially constructed pits, may be possible.

6. Cleanup of the mill site. Contaminated debris and soil are removed, as are roads and parking lots.

7. Ripping, regrading, resoiling, liming, fertilizing, and reseeding as necessary to reestablish vegeta- tion. To enhance its long-term survival, the vegetation selected should be similar to native types.

\section{Tailings Pile Reclamation}

Mill tailings from the leaching and decantation ${ }^{8}$ processes consist of slurries of sands and clay-like particles called "slimes"; the tailings slurries are pumped to tailings piles for disposal. Generally, there are a number of tailings piles and evaporation ponds at each site. Each pile has different characteristics. Groundwater contamination comes mostly from the tailings pile. Depending on the siting and design of the pile, at some sites, the efforts to clean up groundwater to acceptable levels may be extensive.

The ultimate purpose of tailings pile reclamation is to return the site to the DOE or the appropriate State for

${ }^{8}$ For a definition of decantation, see the Glossary. 
perpetual custodial care. Reclamation of tailings must be geared toward reducing direct gamma radiation and the radon emanation from the impoundment area to background, and eliminating the need for an ongoing monitoring and maintenance program following successful reclamation.

The steps involved in cleaning up the tailings piles (Figure 5) are as follows:

1. The edges of the piles are reshaped to minimize erosion hazards from surface runoff. This is done by recontouring the tailings piles or adding material to the base of the pile boundaries.
2. The pile slopes and edges are covered with radon barrier material and rock or other cover (usually a clay or silty material). For erosion protection, "rip rap"9 is the preferred material for a cover. To verify its suitability as a radon barrier, the covering material is tested for its radon diffusion and emanation characteristics as well as its permeability and other physical properties. A plastic and impermeable material is desirable.

3. Drainage in the vicinity is redirected away from the pile. This may require establishing new drainage routes, moving natural stream beds, and/or putting in diversions such as wing dams. The rock

Figure 5. Reclaiming a Tailings Pile
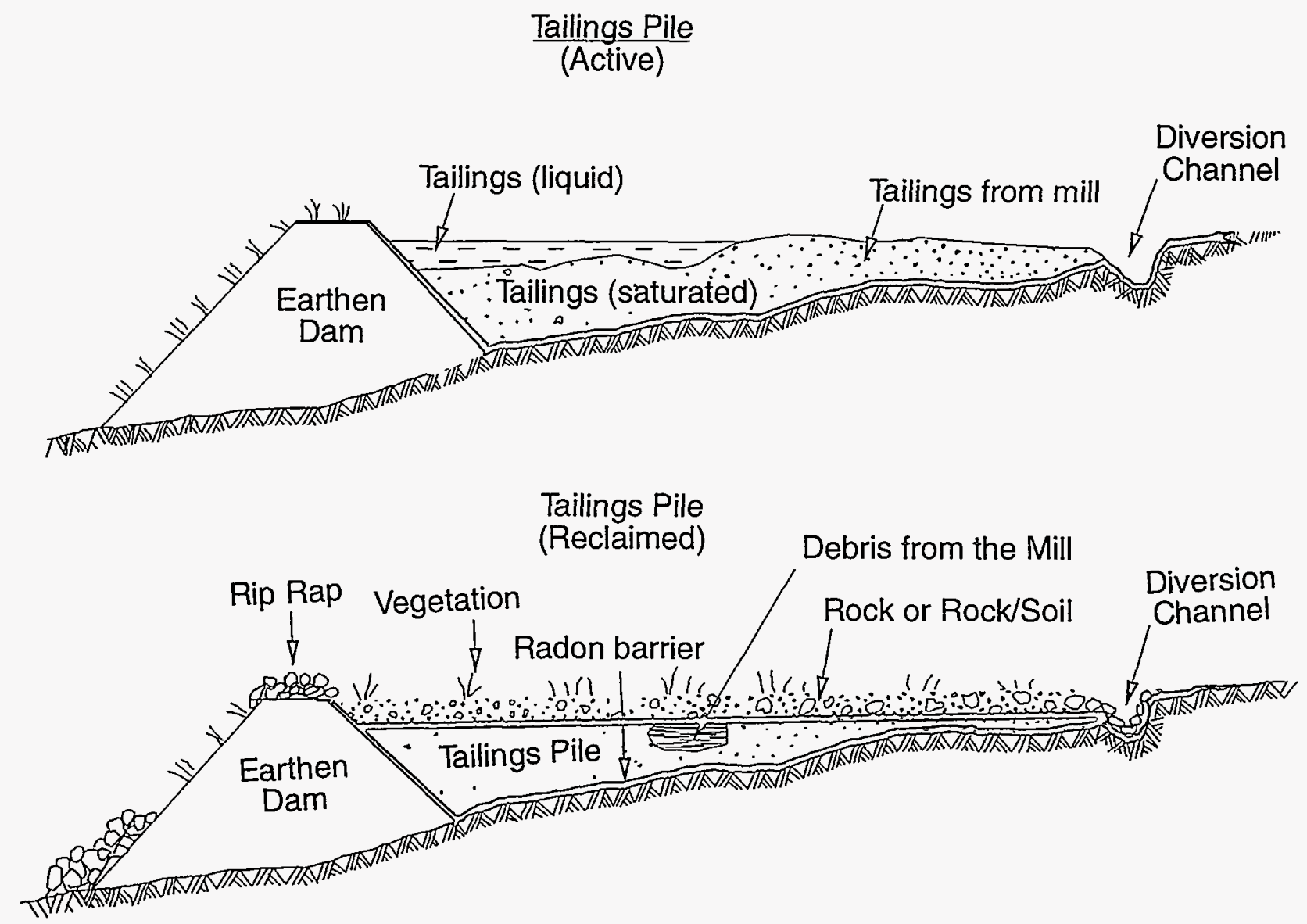

Source: Energy Information Administration, Office of Coal, Nuclear, Electric and Alternate Fuels.

${ }^{9}$ For a definition of rip rap, see the Glossary. 
and other materials used must be resistant to long-term weathering and erosion. Consideration must be given to the maximum possible magnitude of floodwater over the design life of the tailings pile, which is at least 200 years.

4. The pile is allowed to settle and dehydrate. This may take years if the pile is slow in releasing moisture. Generally, pools of liquid on the tailings piles receive additional water from rainfall. The slimy, clay-like nature of the fine materials from the milling process and the lack of capillary action inhibits moisture release and movement to the drying surface. The placement and design of the piles will also affect the length of this stage. Piles placed on porous material without sealing materials will drain through the bottom. Piles with synthetic or clay liners at the base will depend on drainage systems built into the pile or on evaporation. To hasten pile drying, additional moisture should be kept off the pile. New, lined evaporation ponds may be needed to dispose of liquids gathered during the reclamation process. Settlement of tailings must be monitored by establishing survey monuments on the pile and checking their movement, both vertically and laterally.

5. The entire pile is covered with a radon barrier. The material for this cover is usually the same as the material used to cover the edges and slopes of the piles. To verify its suitability, the material used in the new cover must be tested for such characteristics as acidity and radioactivity associated with disposal of heavy metal contaminants. The thickness (from 6 inches to several feet) required to meet standards varies with the nature of the tailings pile and with the material available for cover. Computer models estimate the thicknesses required for the various materials available to meet NRC standards for radiation and radon emanation. This barrier also serves to keep additional moisture off the pile, thus avoiding subsequent drainage into groundwater.

6. The final pile cover is a protection against erosion. It should not be added until the pile settlement is almost complete. Before the new cover is added, the integrity of the previously placed radon cover must be checked and corrected as necessary. The erosion cover may include various types of rocks and earth material, depending on what is available near the site. It may be soil if revegetation is planned, or rock if revegetation is not feasible. Soil amendments, such as lime, may be needed. The site must be monitored for erosion of the soil and growth of the vegetation.

7. The restricted part of the site may be enclosed by a fence.

8. A portion of the area of the tailings pile may be needed for final disposal of wastes at the site, particularly those wastes that may continue to accumulate from groundwater cleanup. It may be necessary to create and build a newly designed disposal area for final disposal of cleanup waste (such as the one being constructed at the Uravan mill site) to allow reclamation of the main tailings pile to proceed to completion.

9. The site is monitored to ensure that all aspects of the design and construction programs have worked as expected, that all standards have been met, and that no unexpected changes have occurred at the site. Until the site reclamation is completed and approved by the NRC, this work is the responsibility of the licensee. When the work is completed, title to the site and the responsibility for long-term surveillance, monitoring, and maintenance of the site are turned over to the DOE or the appropriate State.

Even if a decommissioning plan is approved by Federal or State agencies, it may be necessary to alter the plan over time to accommodate newer, more stringent regulations. For example, mined-out pits can make convenient dumps for mill tailings (Figure 6). If the mine is some distance away from the milling area, as is the case with most sites, haulage costs make this option uneconomical. The few conventional operations that have mined-out pits on site do not have this problem. Potentially, however, using the pits as disposal areas may present significant environmental problems. Seepage into the groundwater can be more difficult to control in a pit than on the surface. The most convenient options are not necessarily the most practical nor the least costly.

The important part of the tailings reclamation is to eliminate characteristics that could influence the magnitude and likelihood of failure ${ }^{10}$ for each potential failure mechanism (Table 2). One must give careful consideration to potential physical and chemical causes of failure affecting major failure elements (such as,

${ }^{10}$ For a definition of failure, see the Glossary. 


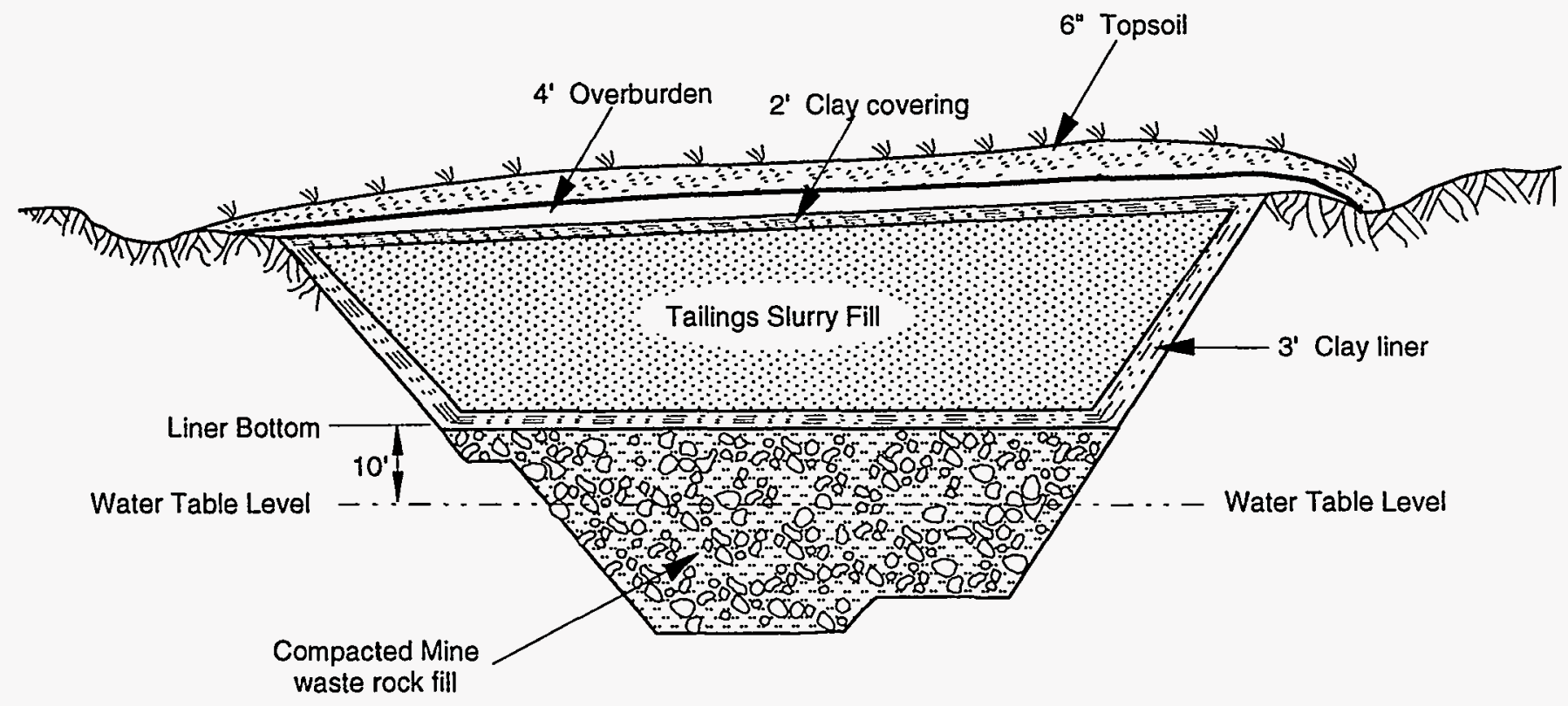

Source: Energy Information Administration, Office of Coal, Nuclear, Electric and Alternate Fuels.

Table 2. Causes of Potential Failure in Tailings Piles

\begin{tabular}{|c|c|c|c|c|c|}
\hline Cause of Failure & \multicolumn{5}{|c|}{ Tailings Element Affected } \\
\hline Gullying $^{a} \ldots \ldots \ldots \ldots \ldots \ldots \ldots$ & $\mathrm{x}$ & & $x$ & & \\
\hline Water Sheet Erosion $\ldots \ldots \ldots \ldots \ldots \ldots$ & $\mathrm{x}$ & & $x$ & & \\
\hline Shrinkage $\ldots \ldots \ldots \ldots \ldots \ldots \ldots$ & $\mathrm{x}$ & & & & \\
\hline Subsidence of Subsoil $\ldots \ldots \ldots \ldots \ldots \ldots$ & & $\mathrm{x}$ & & & \\
\hline Physical Penetration . . . . . . . . . . & & $\mathrm{x}$ & & & \\
\hline Slope Failure $\ldots \ldots \ldots \ldots \ldots$ & & & $x$ & & $x$ \\
\hline Flooding $\ldots \ldots \ldots \ldots \ldots \ldots \ldots$ & $x$ & & $\mathrm{x}$ & & \\
\hline
\end{tabular}

a Gullying is activity of a deep ditch or channel cut in the tailings pile or embankment by running surface water after a downpour. ${ }^{b}$ Chemical erosion is an erosion of soil or embankment due to presence of acid generating chemical elements that interact with atmosphere or surface water.

Source: Energy Information Administration, Office of Coal, Nuclear, Electric, and Alternate Fuels. 
covers, liners, embankment, vegetation and diversion structures). In addition to such elemental failure mechanisms, natural phenomena such as earthquakes, floods, windstorms, tornadoes, glaciation, fire, and pestilence also must be considered.

\section{Groundwater Restoration}

The general approach to controlling groundwater problems is to restrict the generation of additional contaminated groundwater, prevent the movement of such water from the site, and collect it (as necessary) for treatment and recycling. "Reverse osmosis" and "groundwater sweep," the two common groundwater cleanup methods, are discussed in Chapter 3.

The groundwater restoration process comprises the following steps:

1. Wells and piping systems are established in and around the site area to collect the groundwater and to monitor its quality.

2. Cutoff ditches and drains to bedrock may be placed where drainage occurs from the site, such as at the base of the tailings pile.

3. Input and collection wells may be built to prevent groundwater from moving through geological formations and off the site.

4. Limiting the amount of surface water entering the site can reduce groundwater flows. The protective cover on the tailings piles has been demonstrated to reduce the amount of contaminated groundwater generated and to expedite cleanup.

5. Interception of groundwater entering the site by use of wells or underground openings can reduce potential contamination.

6. Lined evaporation ponds may be needed for disposal of collected contaminated groundwater. New ponds may be needed to minimize additional contamination. Spray systems may be installed to speed evaporation in the ponds. Solid wastes may be disposed of in the tailings pile or at some other final disposal site. Thus, a final disposal location must be kept available until the last phases of the project.
7. It may be necessary to treat the collected groundwater.

8. Groundwater must be collected and monitored, and appropriate steps must be taken until standards are met.

\section{Decommissioning Cost Components $^{11}$}

As of January 1, 1994, of the 26 licensed conventional uranium processing mills in the United States, none were operational, 6 were on standby, and 20 were either decommissioned or in various stages of decommissioning (Table 1). Decommissioning costs were analyzed for the conventional production facilities with sufficiently complete data. Data were obtained directly from licensees or from the licensees' filings with "agreement" States or the NRC. Decommissioning, especially the groundwater restoration, will take many years; thus, actual costs are not known. To simplify the analysis, costs are distributed into the following basic categories:

1. Dismantling of mill and reclamation of mill site

2. Reclamation of tailings piles

3. Restoration of groundwater

4. Indirect costs (contingency, overhead, profit, and long-term surveillance and control of the reclaimed areas).

Total decommissioning costs are estimated at more than $\$ 250$ million (Table 3). For conventional mills, total decommissioning costs range from $\$ 4.1$ million to $\$ 38.3$ million (Figure 7). Tailings reclamation costs account for the major part of the total decommissioning costs (Table 4 and Figure 8). The quantity of tailings usually increases commensurate with the length of time the mill operates, and the costs tend to increase accordingly. Generally, mills that operate briefly have lower decommissioning costs, since they generate fewer tailings. ${ }^{12}$

Total decommissioning costs include not only those funds allotted to the various cleanup activities ${ }^{13}$ but also a mandatory 15-percent contingency fee plus a 10percent allowance for overhead and profit, which were added to approximate the decommissioning costs that would be incurred if the reclamation work were carried

\footnotetext{
${ }^{11}$ Data for this section are the most current as of January $1,1994$.

${ }^{12}$ The decommissioning costs for both conventional and nonconventional uranium production facilities and their dependence on key variables are examined in Appendix B.

${ }^{13} \mathrm{Mill}$ dismantling, tailings reclamation, and groundwater restoration.
} 
Table 3. Estimated Decommissioning Costs for Conventional Uranium Production Facilities ${ }^{\mathrm{a}}$ as of January 1, 1994

(Thousand Dollars)

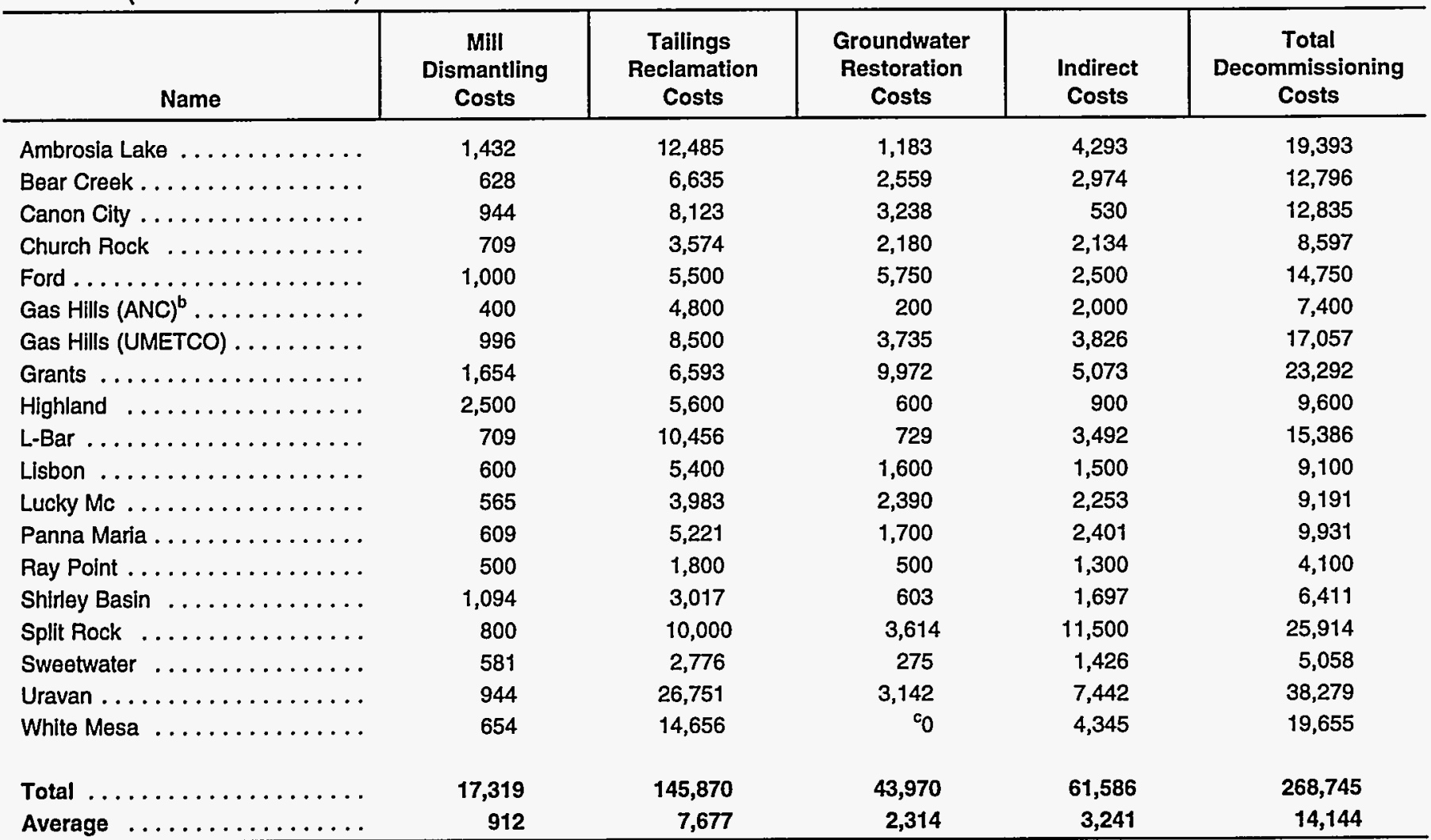

${ }^{a}$ The following sites did not have complete data and are excluded from this table: Bluewater, Edgemont, Falls City, Moab, Petrotomics, Sherwood, and Shootering.

${ }^{b}$ American Nuclear Corporation.

White Mesa reported " 0 " for groundwater restoration costs. These costs may have been included under another category. All facilities have at least some groundwater restoration costs.

Source: Cost estimates are based on data from the U.S. Nuclear Regulatory Commission, State agencies, or licensees.

out by a third party. The fee and allowances are included in determining the amount of the surety bond necessary for decommissioning.

In practice, the use (to various degrees) of licensees' employees for reclamation work may hold down actual costs. The goal of the NRC in obtaining and reviewing costs is solely to determine an adequate surety. Thus, if the estimate is sufficiently high, the accuracy of the various estimated components and the costs of activities completed in the past are of less concern.

Even when the comparison is limited to conventional operations, decommissioning costs vary substantially by site, and caution should be used when calculating or interpreting "average" costs. A simple average of costs is meaningless, and even a weighted average should not be confused with a "typical" or "common" cost. For example, the average tailings reclamation cost per ton at conventional sites is $\$ 0.97$, with a range from $\$ 0.29$ at Grants mill site to $\$ 4.99$ at L-Bar mill site in New Mexico. The range is even broader for average tailings costs per acre, from $\$ 9,253$ at the Sweetwater mill to $\$ 314,718$ at the Uravan mill (Table 4). Generally, reclamation costs per ton of tailings tend to be lower at mills with higher tailings piles, since the cost is largely determined by the lining and covering expenses. As more tailings are generated, the height of the pile can be increased so long as the slope is maintained at a safe level. At some of the larger sites, the estimated average height of the tailings pile(s) exceeds 50 feet. Such tailings piles require less lining and covering on a per ton basis and result in lower reclamation cost per ton of tailings. The unit costs (costs per ton of tailings) are usually lower at big mills because more tailings are stored per acre. A comparison of the tailings generated by mill with the average cost per ton reflects this inverse relationship. Ambrosia Lake produced the most 
Figure 7. Estimated Total Decommissioning Costs for Conventional Facilities as of January 1, 1994

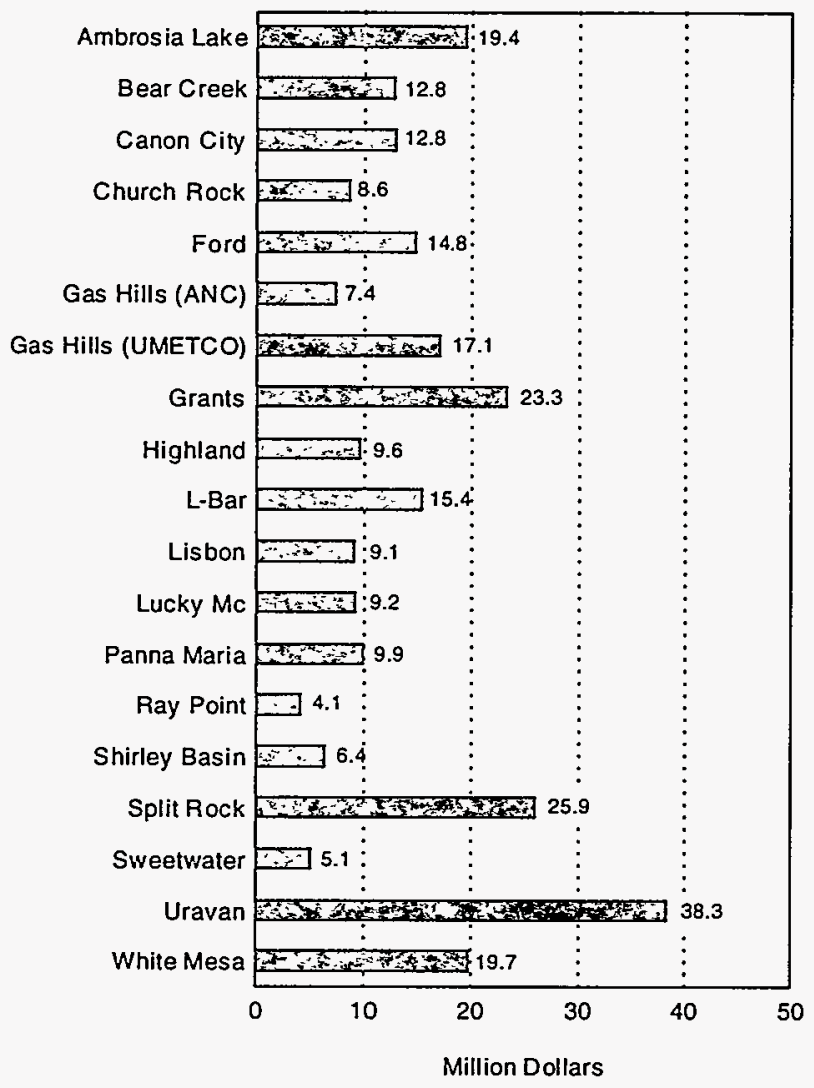

Source: Cost estimates are based on data from U.S. Nuclear Regulatory Commission, State agencies, or licensees.

tailings but is among the lowest in unit costs. Small producers, such as L-Bar and Ray Point, appear at the opposite end of the scale. While most mills fit this pattern, some of the exceptions illustrate that certain actions, such as the sharing of a tailings pile by two or more mills or the utilization of on-site personnel to do some or all of the work, can result in significant savings.

The wide range of costs for different sites reflects differences in tailings pile design and configuration and in the required reclamation measures. For example, some sites may require relocating of tailings piles. Recently built mill sites incorporate better design features (such as liners for tailings ponds) that should reduce groundwater restoration costs. The highest decommissioning costs are seen at mills that were built earliest and had the longest periods of operation, accumulating more tailings than at the newer mills and operating with fewer environmental controls.
Each site presents unique geographic and environmental conditions. The purpose of the analyses is to identify general economic trends that might be applicable to future sites. The 26 conventional mills are described individually in the following paragraphs. The information in the graphics accompanying the text is from U.S. Nuclear Regulatory Commission, State agencies, or licensees.

Ambrosia Lake. The Ambrosia Lake mill, located near Grants, in McKinley County, New Mexico, is owned by the Quivera Mining Company. Formerly a subsidiary of the Kerr-McGee Corporation, Quivera is now a subsidiary of the Rio Algom Mining Corporation. The mill ceased processing ore in March 1985, but it continues to extract uranium from the mine water and is currently on standby status. The reclamation costs per ton of tailings at the Ambrosia Lake mill, largest in capacity of all the mills, were approximately one-fourth as much as those at the Gas Hills (UMETCO) site, location of one of the smallest mills.

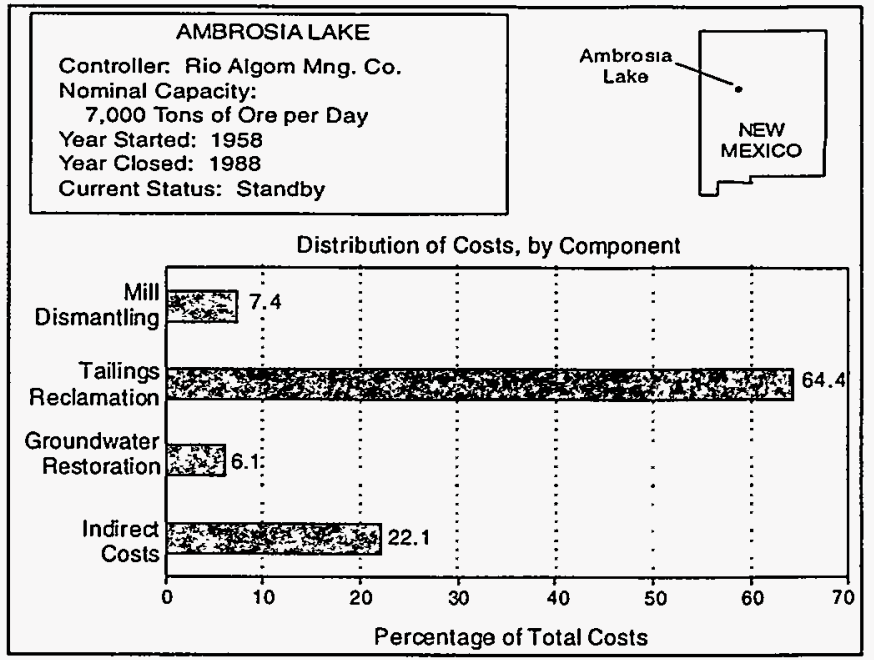

Bear Creek. Union Pacific's Bear Creek mill in the Powder River Basin area in Converse County, Wyoming, has been dismantled and the tailings being reclaimed. Groundwater cleanup is in progress, and the evaporation ponds remain. Bear Creek mill had a daily ore processing capability of 2,000 tons. The mill dismantling costs were below average, but the savings were more than offset by the higher-than-average tailings reclamation costs per ton and per acre.

Bluewater. ARCO's Bluewater near Grants in Valencia County, New Mexico, ranks second among conventional sites in ore processing capacity, tailings quantity, and age. It began operations three decades ago and is 
Table 4. Mill Tailings Reclamation Summary as of January 1, 1994

\begin{tabular}{|c|c|c|c|c|c|c|c|c|}
\hline Mill $^{8}$ & $\begin{array}{c}\text { Tailings } \\
\text { Area } \\
\text { (Acre) }\end{array}$ & $\begin{array}{l}\text { Tailings } \\
\text { Tonnages } \\
\text { (Thousand } \\
\text { Tons) }\end{array}$ & $\begin{array}{l}\text { Tailings } \\
\text { Reclamation } \\
\text { Costs }^{b} \\
\text { (Thousand } \\
\text { Dollars) }\end{array}$ & $\begin{array}{c}\text { Total } \\
\text { Decommissioning } \\
\text { Costs }^{\mathrm{b}}\end{array}$ & $\begin{array}{l}\text { Tailings } \\
\text { Cost }^{b} \\
\text { per Ton } \\
\text { (Dollars) }\end{array}$ & $\begin{array}{c}\text { Total } \\
\text { Decommissioning } \\
\text { Costs }^{\mathrm{b}} \\
\text { per Ton } \\
\text { (Dollars) }\end{array}$ & $\begin{array}{l}\text { Tailings } \\
\text { Cost }^{b} \\
\text { per Acre } \\
\text { (Dollars) }\end{array}$ & $\begin{array}{l}\text { Tailings } \\
\text { Tons } \\
\text { per Acre }\end{array}$ \\
\hline Ambrosia Lake .... & 328 & 33,180 & 12,485 & 19,393 & 0.38 & 0.58 & 38,064 & 101,159 \\
\hline Bear Creek . . . . . . . & 150 & 4,740 & 6,635 & 12,796 & 1.40 & 2.70 & 44,233 & 31,600 \\
\hline Ford $\ldots \ldots \ldots \ldots$ & 133 & 3,086 & 5,500 & 14,750 & 1.78 & 4.78 & 41,353 & 23,203 \\
\hline Gas Hills $\left(\right.$ ANC) ${ }^{c} \ldots$ & 117 & 5,842 & 4,800 & 7,400 & 0.82 & 1.27 & 41,026 & 49,932 \\
\hline Gas Hills (UMETCO) . & 146 & 8,047 & 8,500 & 17,057 & 1.06 & 2.12 & 58,219 & 55,116 \\
\hline Grants ......... & 215 & 22,377 & 6,593 & 23,292 & 0.29 & 1.04 & 30,665 & 104,079 \\
\hline Highland $\ldots \ldots \ldots$ & 290 & 11,354 & 5,600 & 9,600 & 0.49 & 0.85 & 19,310 & 39,152 \\
\hline Ray Point . . . . . . . & 45 & 441 & 1,800 & 4,100 & 4.08 & 9.30 & 40,000 & 9,800 \\
\hline Shirley Basin . . . . & 263 & 8,157 & 3,017 & 6,411 & 0.37 & 0.80 & 11,471 & 31,015 \\
\hline Split Rock ...... & 167 & 7,716 & 10,000 & 25,914 & 1.30 & 3.36 & 59,880 & 46,204 \\
\hline Sweetwater ..... & 300 & 2,315 & 2,776 & 5,058 & 1.20 & 2.18 & 9,253 & 7,717 \\
\hline Uravan . . . . . . . . & 85 & 10,472 & 26,751 & 38,279 & 2.55 & 2.66 & 314,718 & 123,200 \\
\hline White Mesa ..... & 333 & 3,527 & 14,656 & 19,655 & 4.16 & 5.57 & 44,012 & 10,592 \\
\hline Total & 3,485 & 151,237 & 145,870 & 268,745 & & & & \\
\hline Average $\ldots .$. & 183 & 7,960 & 7,677 & 14,144 & 0.97 & 1.78 & 41,857 & 43,397 \\
\hline
\end{tabular}

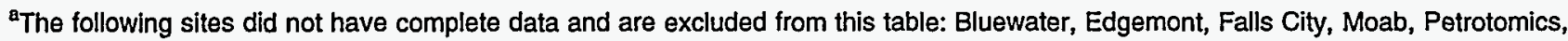
Sherwood, and Shootering.

${ }^{b}$ All costs are estimated.

'American Nuclear Corporation.

Note: Totals may not equal sum of components because of independent rounding.

Source: Tailings tonnages are extracted from U.S. Department of Energy, Washington, DC, March 1994, Integrated Data Base for 1993: "U.S. Spent Fuel Radioactive Waste Inventories, Projections, and Characteristics." Cost estimates are based on data from the U.S. Nuclear Regulatory Commission, State agencies, or licensees.

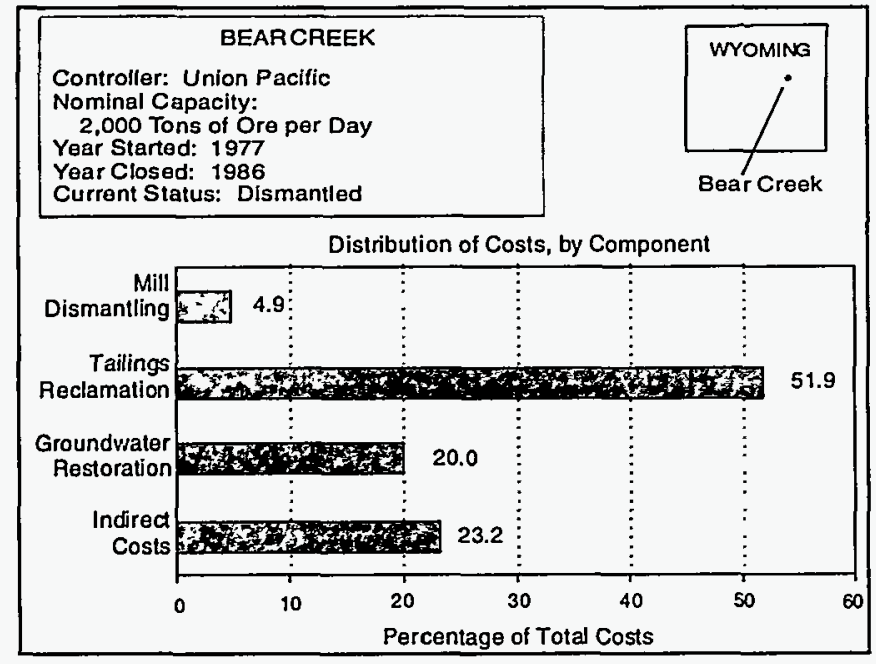

now being decommissioned. The mill has been dismantled, and the site has been topsoiled and revegetated. It is the largest of the seven mills missing from the analysis due to incomplete or nonexistent data.

Canon City. The Canon City mill in Jefferson County, Colorado, is owned by the Cotter Corporation, a subsidiary of Commonwealth Edison. Constructed in 1979, the Canon City site is licensed by the Colorado Department of Health. The current mill occupies the site of the original mill, built in 1958. Groundwater restoration work is continuing at Canon City, and is currently on standby. The decommissioning cost data were supplied for this report by the Cotter Corporation. Cotter notes that, regarding the total for groundwater restoration costs, "the $\$ 3,238,000$ represents the cost of construction and some of the operations and maintenance costs 
Figure 8. Major Components of Estimated Decommissioning Costs for Conventional Facilities as of January 1, 1994

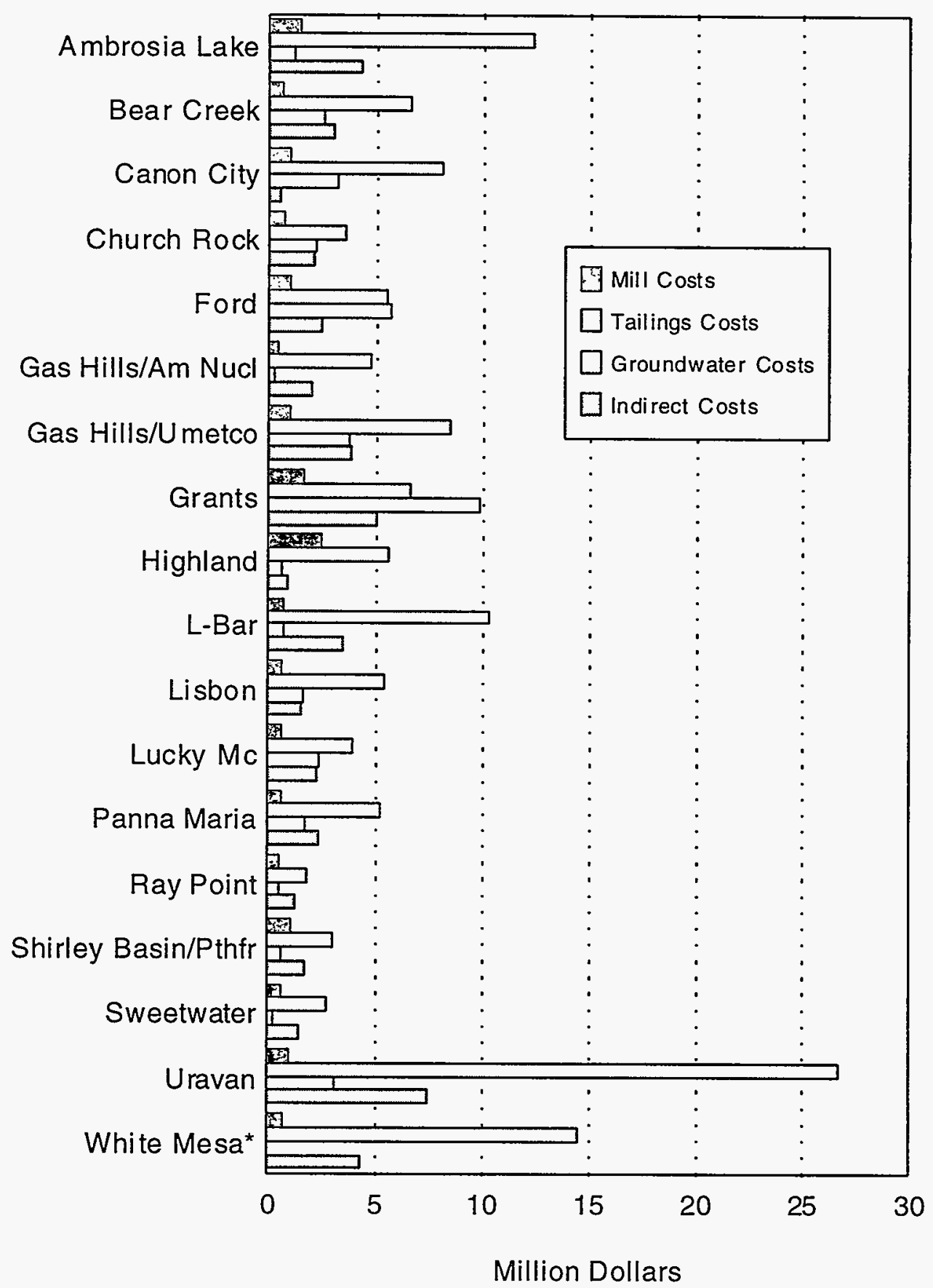

*No groundwater costs reported for this site.

Source: Costs estimates are based on data from the U.S. Nuclear Regulatory Commission, State agencies, and licensees. 


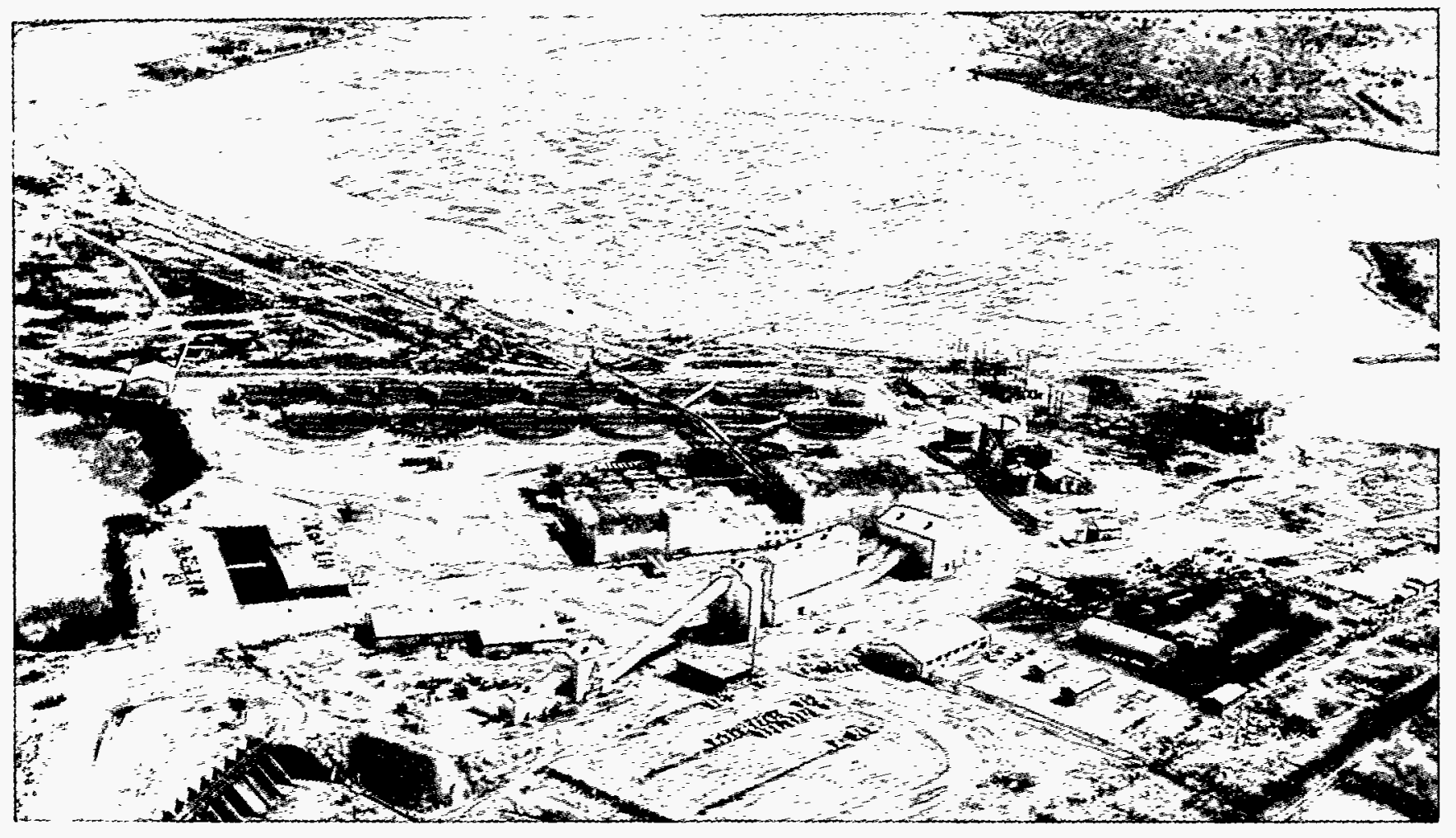

Rio Algon's Ambrosia Lake mill site located near Grants, New Mexico which shows the mill in the center foreground and the tailings piles in the background. (December 1969)

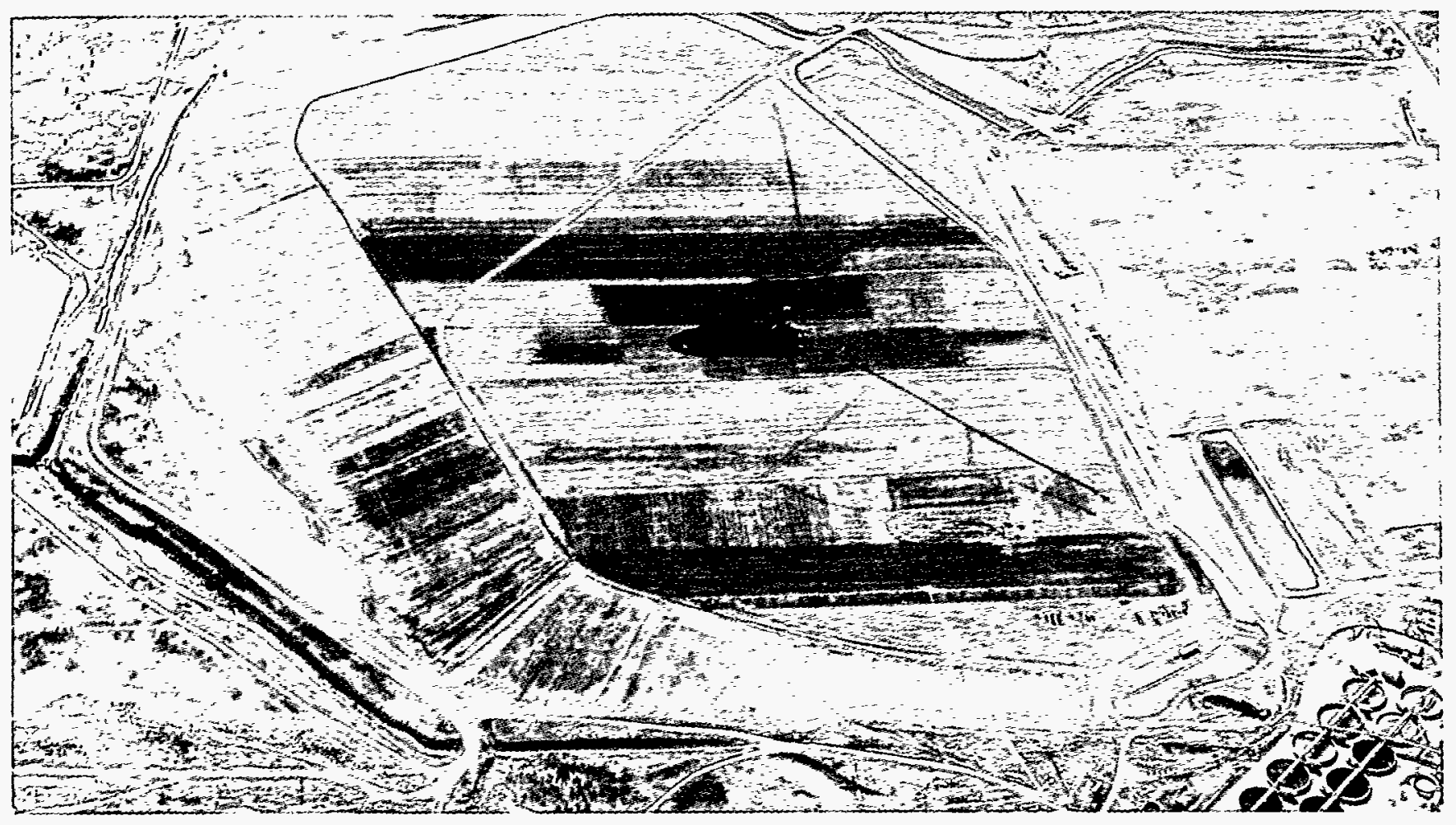

Rio Algon's Ambrosia Lake mill site located near Grants, New Mexico which shows partially reclaimed tailings piles in the center portion of the photograph. The lower right hand comer shows a small segment of the mill and the area in the upper right-hand corner shows the borrow area from which the black shales are supplied for radon barrier being placed over the tailings pile. (November 1993) 
associated with Cotter's Remedial Action Plan from 1988 to present." Not all of the operations and maintenance costs associated with Cotter's plan are available at this time. It should be noted that future Remedial Action Plan costs are not included in this figure.

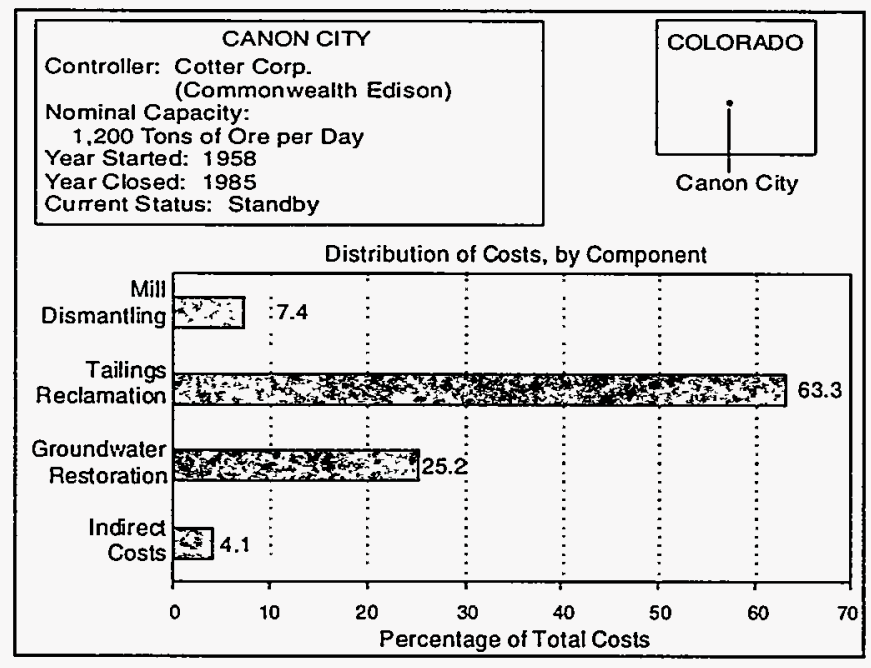

Church Rock. The mill has been dismantled and tailings reclamation work is in progress. Church Rock is slightly smaller in capacity than the Grants mill, which is also located in McKinley County, New Mexico, and began operation in the same year, 1958. Church Rock utilized a uranium recovery process that involves acid leaching, while Grants relied on a carbonate process.

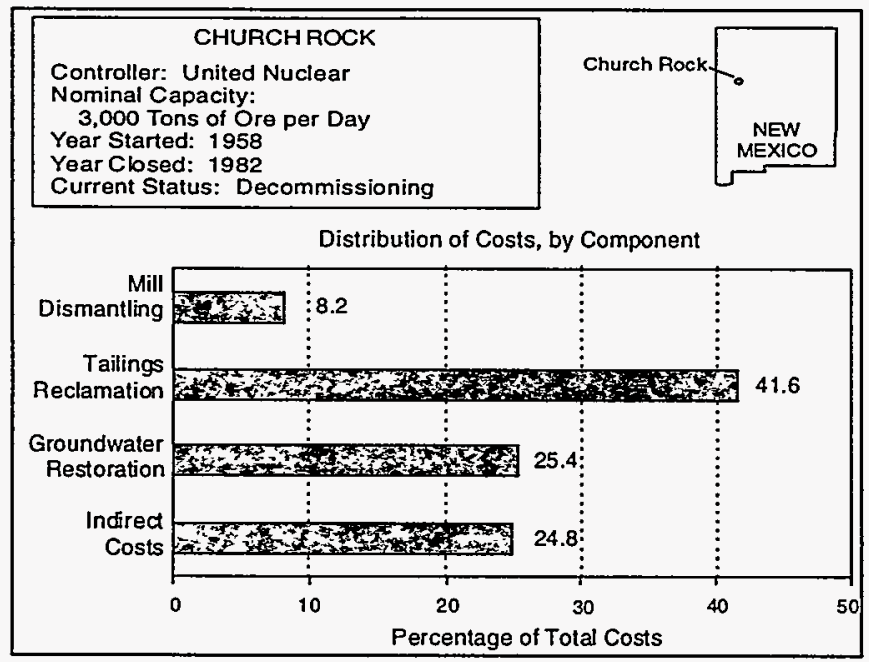

Edgemont. The Edgemont mill in Fall River County, South Dakota, is the only mill discussed in this report that was operated by the Tennessee Valley Authority (TVA). Edgemont ceased operation in the early 1970's, a time of less stringent reporting requirements. With the passage of time, many of the data were either lost or destroyed. Tailings were moved to a new location a few miles southeast on a partially excavated site with an impervious shale base. The tailings were covered, vegetation was established, and the area was fenced. The mill was dismantled. The original mill and tailings site has now been released for general use. TVA has elected to retain title to the new tailings pile and is negotiating with NRC regarding additional erosion prevention steps required to meet current NRC regulations. TVA reports that an estimated $\$ 33$ million has been spent on decommissioning the Edgemont site.

Falls City. Continental Oil Company's Falls City mill in Karnes County, Texas is regulated by the State of Texas. The mill has been dismantled, and the tailings work is nearly complete. The available data for this site were not sufficient for analysis in the report.

Ford. Dawn Mining Company owns the Ford mill, located in Stevens County, near Ford, Washington. Dawn Mining Company is owned by the Newmont Mining Company (51 percent ownership) and by Midnite Mines, Inc. Sixty percent of Midnite Mines, Inc., is controlled by members of the Spokane Indian Tribe in Washington. Much of the equipment has been removed. The ball mill ${ }^{14}$ has been sold, and some of the pumps have been moved to the Midnite Mine. Two

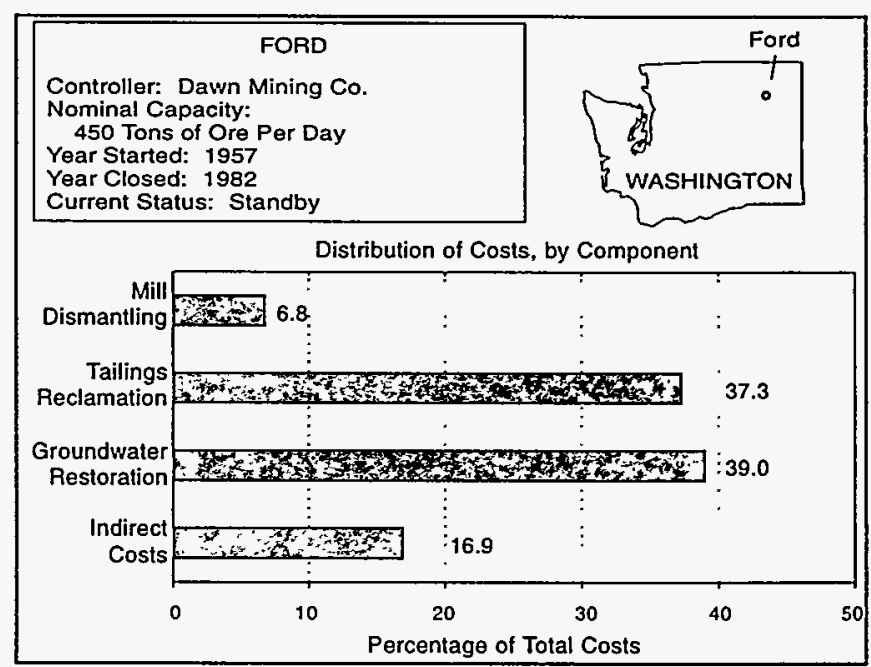

${ }^{14}$ For a definition of ball mill, see the Glossary. 
of the four pits at the site have been filled in, and one pit still contains uranium-bearing water requiring further cleanup. The Dawn Mining Company has requested permission from the State of Washington to operate part of the previously closed mill to process water from open pit mines. A water treatment facility has been built to assist in this task. Complete cost data for the Ford site were not available through public sources at the time of this report. Dawn Mining Company supplied the information in response to a written request by the EIA.

Gas Hills (American Nuclear Corporation). Work is underway on tailings pile reclamation and groundwater cleanup. The mill, situated in Fremont County, Wyoming, has been dismantled and the site is being reclaimed. With a rated ore-processing capacity of 950 tons per day, this is one of only four mills that was rated below 1,000 tons. Because complete cost data were not yet available through public sources, the EIA requested the information from American Nuclear Corporation (ANC). Gas Hills is one of six sites that supplied data specifically for this report. The ANC is currently out-of-business, and asking the State of Wyoming to do the reclamation work.

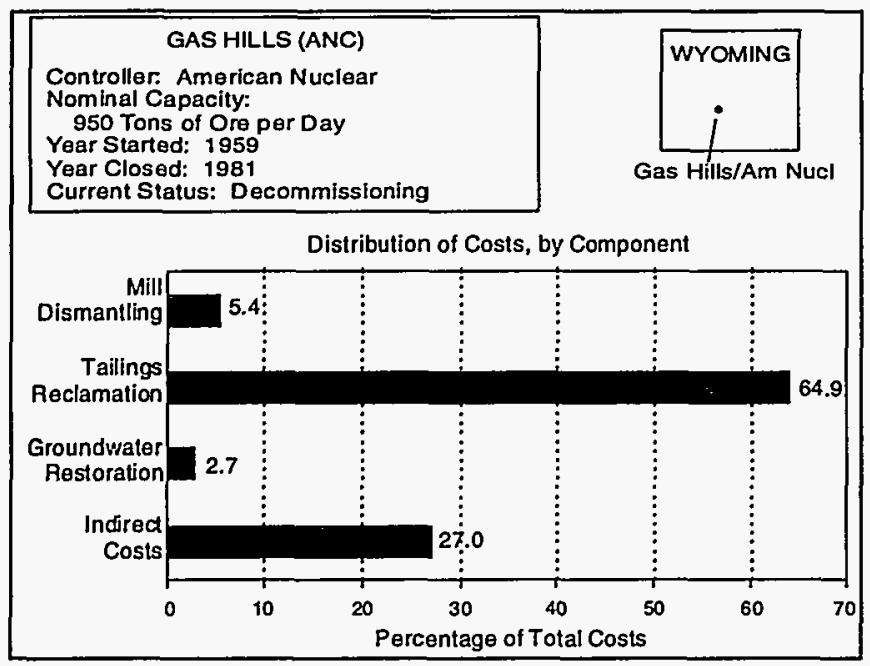

Gas Hills (UMETCO). UMETCO, a subsidiary of the Union Carbide Corporation, owns this mill located in the Gas Hills region near Natrona Fremont County, Wyoming. The mill is being decommissioned. The mill itself has been dismantled and the site is being reclaimed. The tailings piles are in various stages of "rip-rapping." Although UMETCO has reclaimed much of the tailings disposal area, the Gas Hills mill site is still being used to dispose of waste material from other sites. UMETCO has been accepting byproduct materials for disposal under short-term contracts. All of this material appears to have been placed in a claylined pit. A "reverse osmosis" method is employed in the groundwater restoration at the UMETCO site.

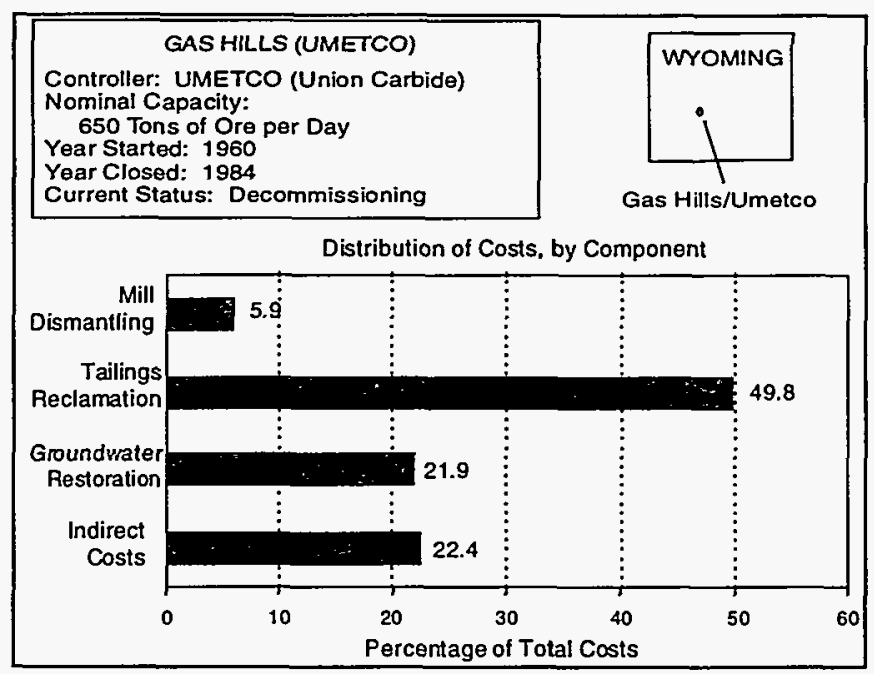

Grants (Homestake). Homestake Mining Company operated the Grants mill located near Milan, McKinley County, New Mexico, through January 1990. Grants was built in 1958 and its capacity was rated at 3,000 tons of ore per day. This mill was also used to process ore from Chevron's Mt. Taylor mine, which closed late in 1989. Grants mill is in the process of decommissioning. The decommissioning plan with detailed cost components for Homestake Mining Company's Grants site was made available to the EIA by the licensee. The plan is discussed in detail in Appendix B.

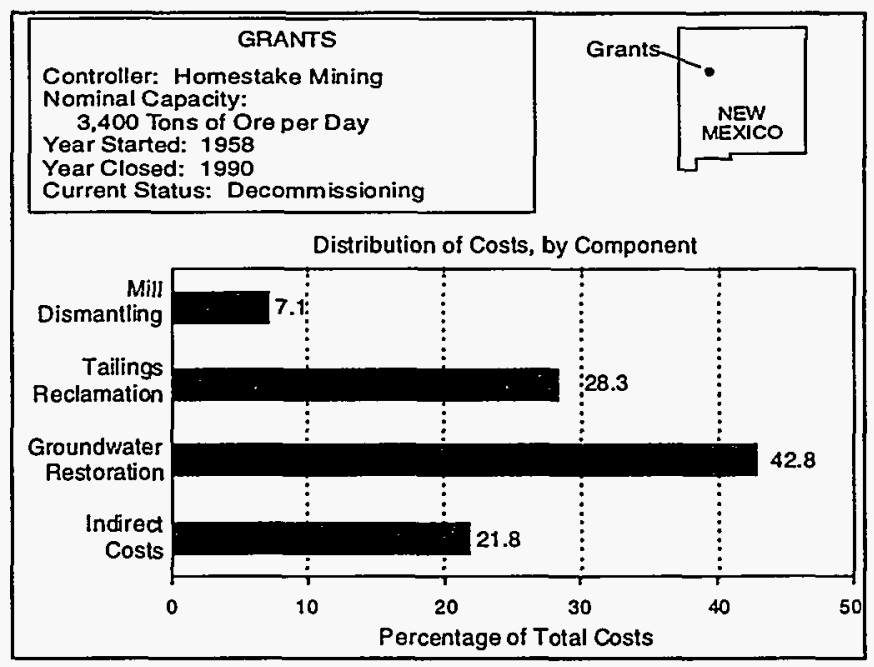

Highland. The Highland mill in the Powder River Basin area in Converse County, Wyoming, has been dismantled, and the tailings from the mill have been 
reshaped, covered, and revegetated. Groundwater restoration continues as water is pumped to the evaporation ponds. Cost estimates for decommissioning work completed by Exxon are not available, but information on the cost of work remaining was provided to the NRC. These estimates project that the cost of the remaining work is as follows: $\$ 526,000$ for groundwater restoration and evaporation pond cleanup, $\$ 277,000$ for tailings reclamation, and $\$ 350,000$ for miscellaneous costs.

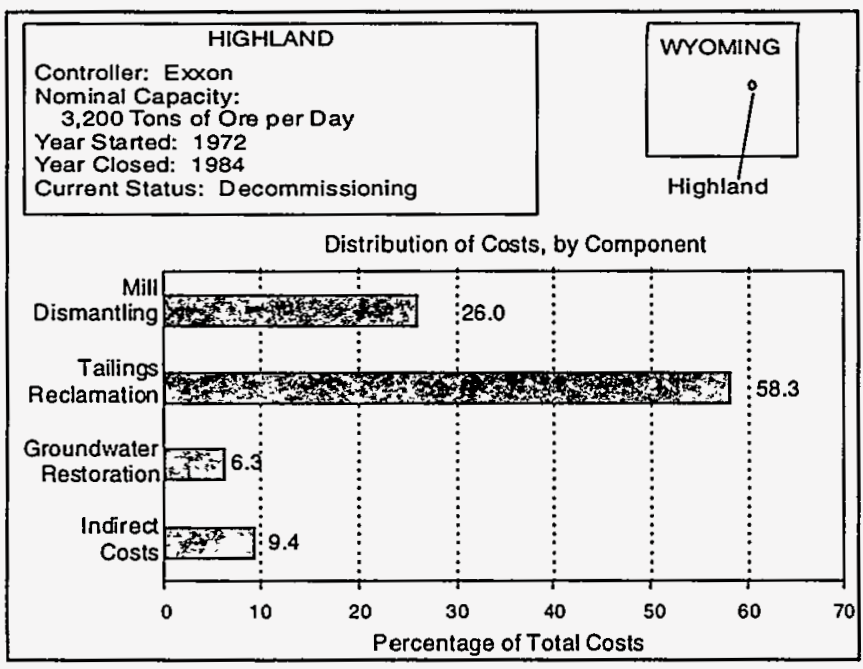

L-Bar. BP America's L-Bar mill located near Ceballeta in Valencia County, New Mexico, is decommissioning, and tailings reclamation is nearing completion. Groundwater restoration is continuing at the site. The L-Bar site has the second highest average tailings costs per ton.

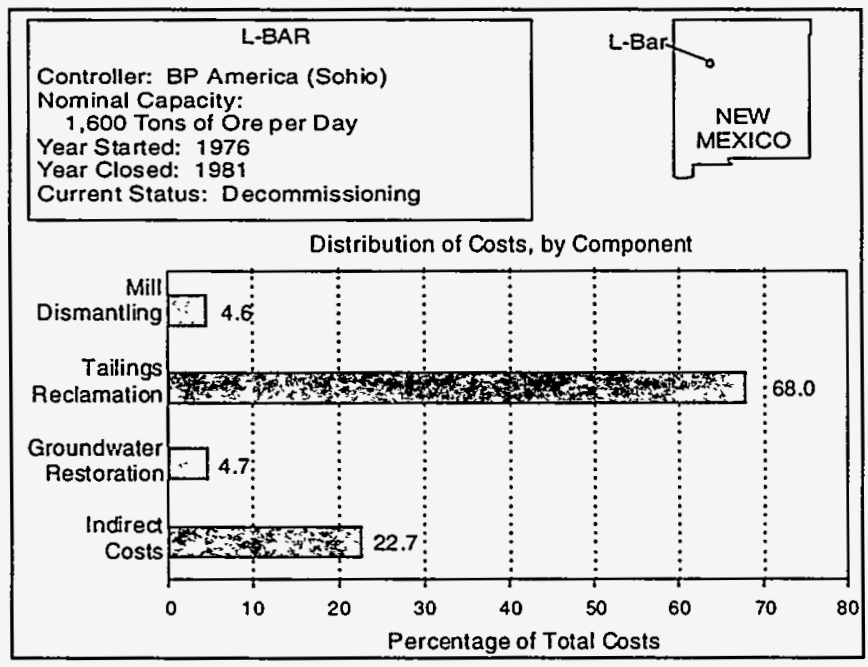

Lisbon. The Lisbon mill in San Juan County near La Sal, Utah, is owned by the Rio Algom Mining Corporation. The mill began operating in 1971 and was closed in November 1988. Rio Algom Mining Corporation has proposed to the NRC a final decommissioning plan for this site. Lisbon produced approximately half as many tailings as the average mill, but only 35 acres were allotted on the site for tailings disposal. If all the tailings are stored at Lisbon, the average height of the tailings pile will be 60 feet. This would rank it second only to Uravan in the thickness of its tailings pile.

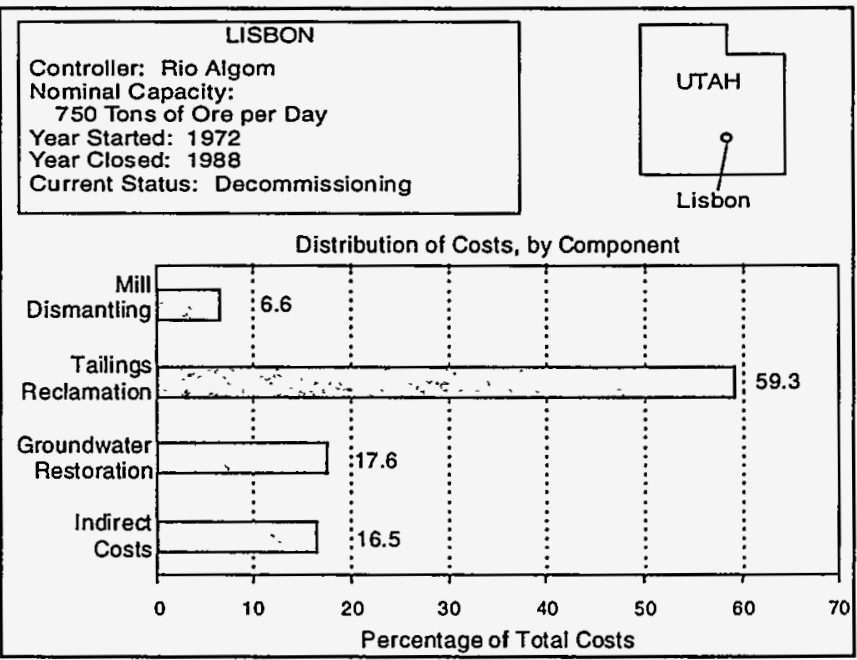

Lucky Mc. Pathfinder Mines Corporation operated two uranium mills in the Gas Hills area in Freemont County, Wyoming: Lucky Mc and Shirley Basin. COGEMA, the French state-owned uranium mining/ enrichment corporation, owns 100 percent of Pathfinder

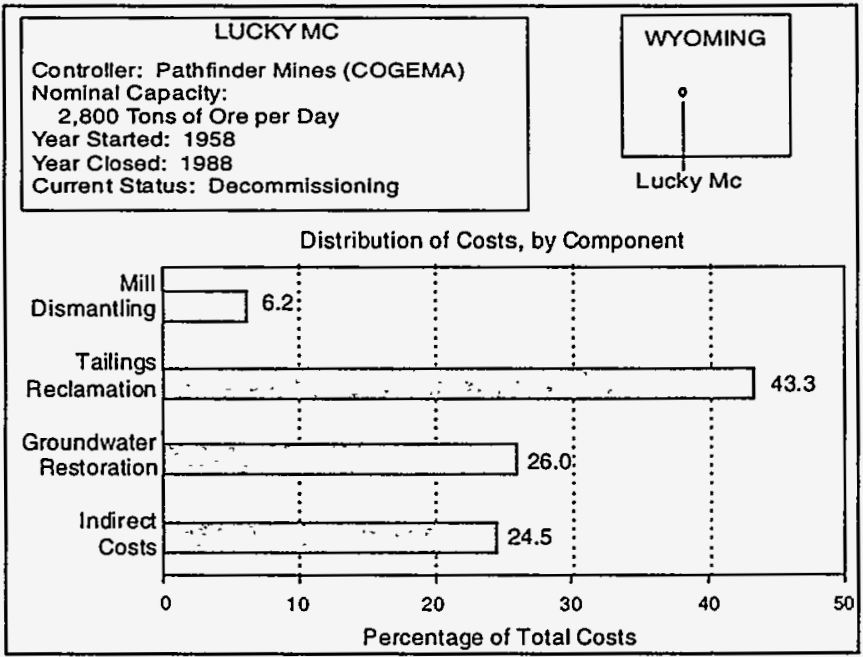


Mines Corporation. The Lucky Mc mill is being dismantled. Operating in four different decades, the Lucky Mc generated nearly 12 million tons of tailings. The average tailings reclamation cost per ton $(\$ 0.34)$ ranks second lowest, next to the Grants mill. The 248-acre tailings area is relatively spacious for a small site. As a result, the reclamation costs per acre are not especially low but are instead very close to the average per site.

Moab. Moab mill in Grand County, Utah, is closed, and the reclamation plan is being developed. The mill site's location, situated in the flood plain next to the Colorado River, raised an exceptional environmental concern. Decommissioning cost data for Moab were not available for this report.

Panna Maria. Chevron Resources operated this mill, located in Karnes County, Texas. The mill received its operating license in September 1979. It had a rated capacity of 3,000 tons of ore per day. Panna Maria is licensed and regulated by the Texas Department of Health. The mill is being decommissioned. Although Chevron remains the licensee of record, the facility has been sold to the General Atomics Corporation.

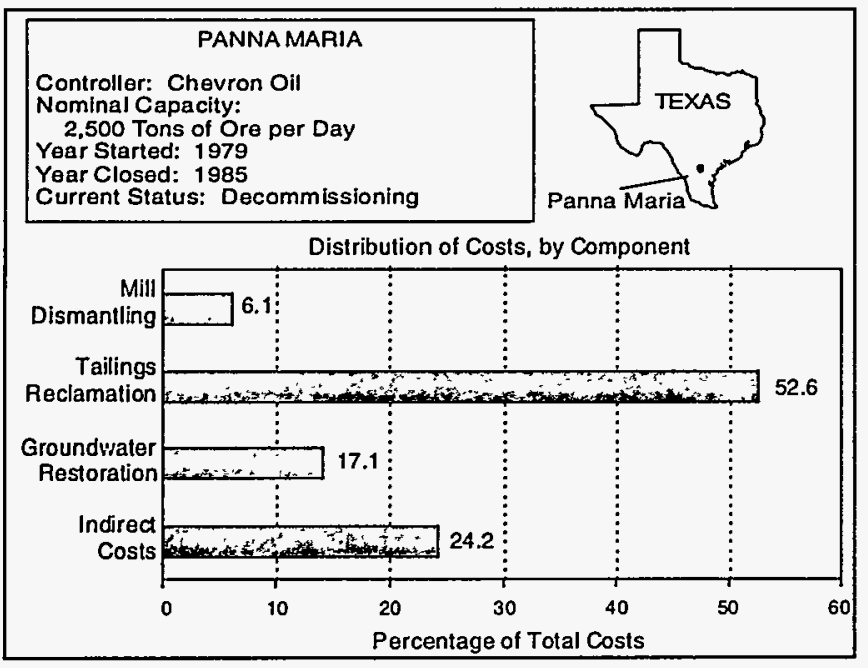

Petrotomics Mill. Tailings reclamation and groundwater restoration are in progress at the Petrotomics site in the Shirley Basin area. The Petrotomics mill began operation in 1962, and it ceased production in 1985. The mill has since been dismantled. The data for the Petrotomics site were not sufficient to include in the analysis.

Ray Point. The mill dismantling costs for the Ray Point site in Live Oak County, Texas, were not available at the time of this report and are, therefore, estimated by the EIA. The tailings reclamation cost total ( $\$ 1.8$ million) is from a 1983 estimate by Exxon Coal and Minerals Company, and the indirect costs are from the company's 1993 estimate. Ray Point is regulated by the State of Texas.

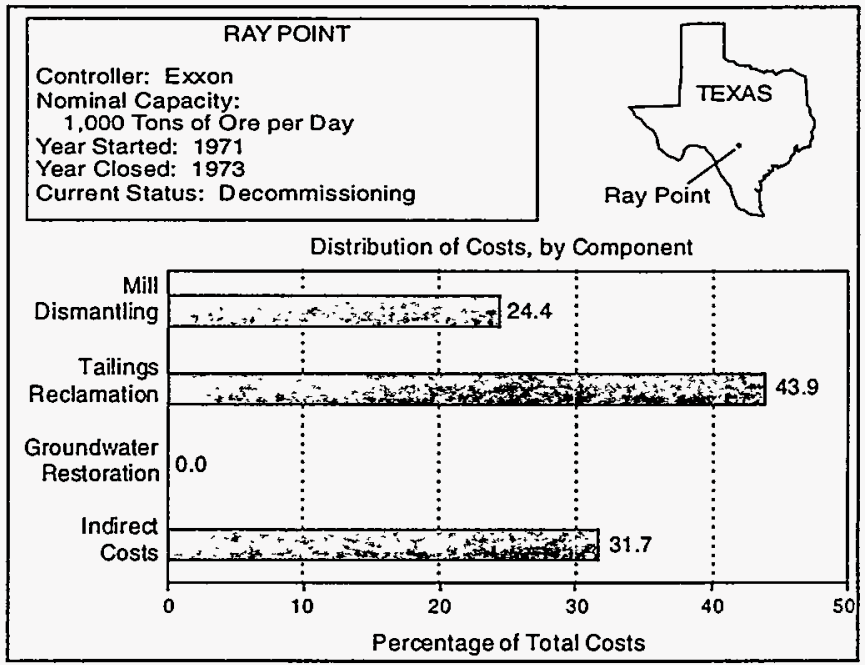

Sherwood. Presumably because the reclamation plan is still under development, decommissioning cost data on the Sherwood site in Stevens County near Wellpinit, Washington, were not available in public files or from the licensee, Western Nuclear, at the time this report was in preparation. The Sherwood mill, regulated by the State of Washington, has been decommissioning and the tailings are dry. Groundwater restoration wells are in place, and surveying and monitoring are in progress.

Shirley Basin. The mill in Carbon County, Wyoming, is being dismantled, having shut down in 1992. The tailings piles have not been completely covered yet because they will be used to accommodate in situ leach

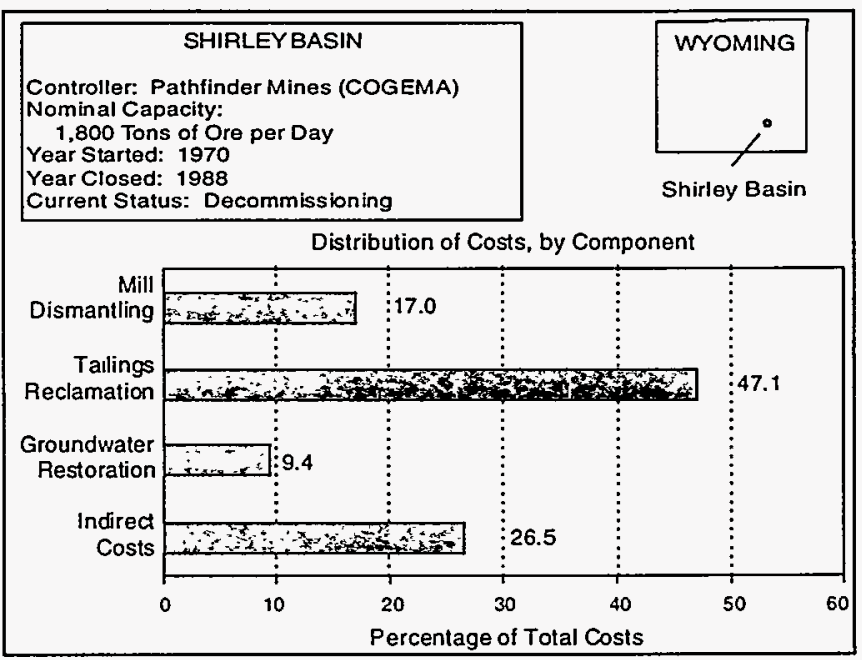


waste. The physical characteristics of the Pathfinder operation might be regarded as "typical" of the mills in this study. The ore processing capacity, estimated output, and tailings area approximate the average per site. The mill generated 8.16 million tons of tailings (the average was 7.68 million tons). With the exception of the mill dismantling costs, however, decommissioning costs at the Pathfinder site tended to be significantly lower than average. Tailings reclamation costs, both total and costs per ton, were about the average per site, and the groundwater remediation costs were about onethird the average. The total costs were about half of the site average. Shirley Basin (Pathfinder) began operation in 1971 and ceased operation in 1988.

Shootering. The mill in Shootering Canyon near Hanksville is owned by Plateau Resources, a whollyowned subsidiary of Consumers Power Company. The mill located in Garfield County, Utah, is a small facility that was used only during test operations. Shootering has not operated commercially since receiving its license in 1979. Because there were no mill tailings generated in commercial production, this operation was excluded from the cost analysis in this report. The mill is currently on standby.

Split Rock. Under a new plan submitted by Western Nuclear, the surety for the Split Rock mill near Jeffery City in Fremont County, Wyoming, is expected to be over \$20 million. The decommissioning cost data for this site were supplied to the EIA by Western Nuclear. The company included the anticipated costs in their calculations for tailings reclamation, groundwater restoration, and indirect costs. The relatively high costs in certain categories at Split Rock compared with other sites may result from the exclusion of anticipated costs in reports by other companies.

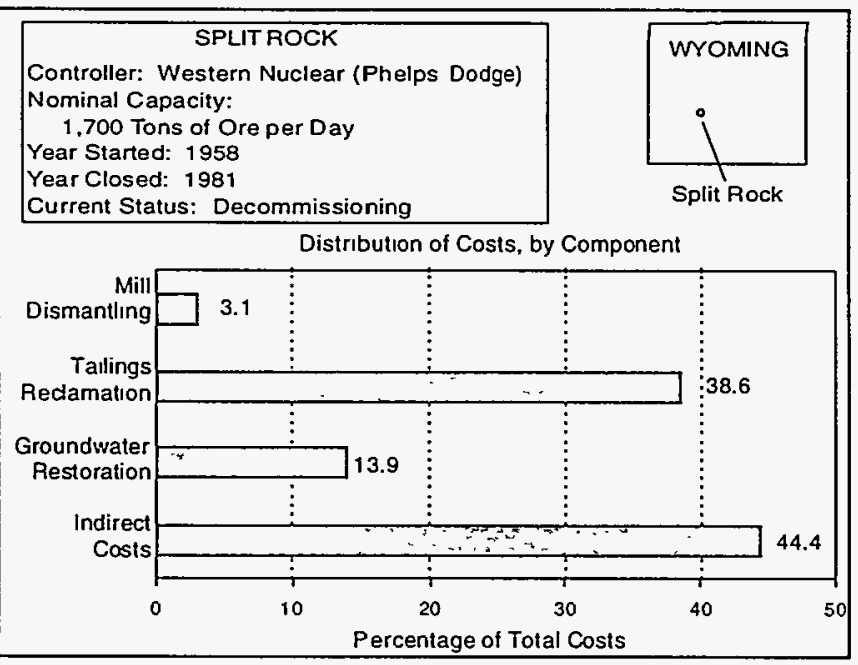

Sweetwater. The mill in the Red Desert area in Sweetwater County, Wyoming, was built by the Minerals Exploration Corporation, a subsidiary of UNOCAL Corporation. Sweetwater began commercial operation in February 1981 and closed indefinitely in April 1983. The mill was first sold to Kennecott Corporation, then recently resold to the Green Mountain Mining Venture. The mill is intact and in good repair and it is expected to operate again in the future.

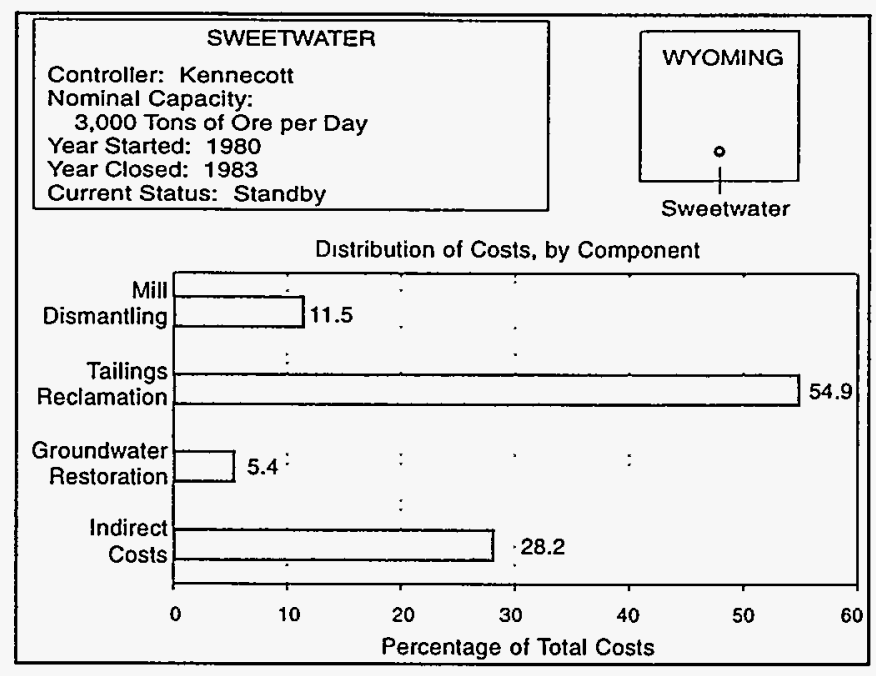

Uravan. Uravan mill site is owned by UMETCO. The mill takes its name from its location in Mesa County, near Uravan, Colorado. The site, regulated by the State of Colorado, is being reclaimed and the mill itself has been demolished. The Uravan decommissioning project has the highest costs, principally because it has the highest tailings reclamation cost of any facility. This site includes remnants from radium and vanadium mill operations, prior to uranium production, and is not

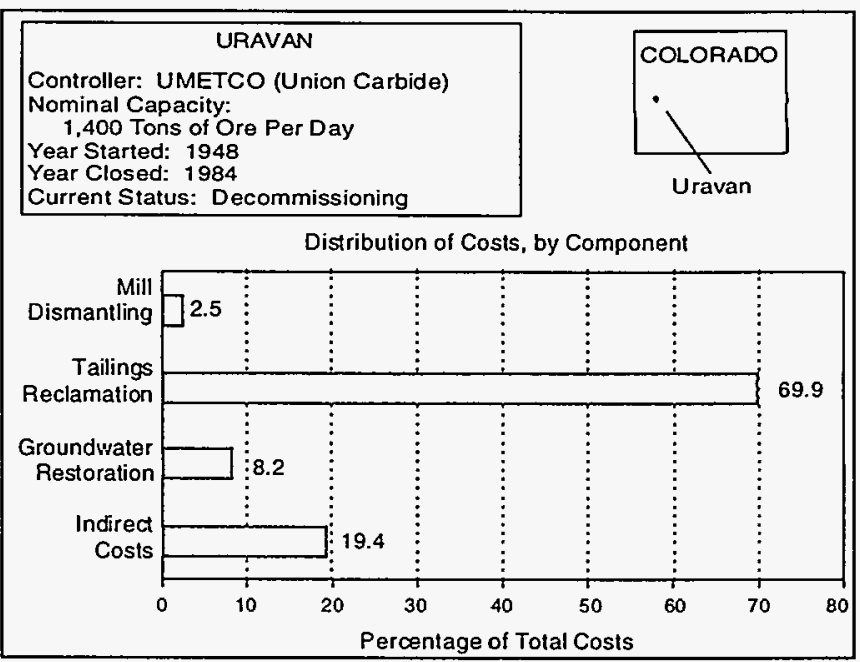


typical of current or future uranium operations. The tailings have been reshaped and rip-rapped, and groundwater restoration is in progress. The older evaporation ponds on the site have been reclaimed and new ones are currently in operation.

White Mesa. Until recently, Energy Fuels Nuclear (EFN) owned 30 percent of the White Mesa mill, located at San Juan County, near Blanding, Utah. The mill was operated by and title was held by the UMETCO Minerals Corporation. In 1994, EFN acquired the remaining 70 percent ownership of the mill from UMETCO. The White Mesa site has the largest tailings area of all conventional sites, 333 acres. A comparison of the White Mesa mill with the Sweetwater mill shows a significant difference in costs per short ton for tailings disposal. Contrary to the pattern at most mills (i.e., smaller unit costs for higher producers), the unit costs are actually significantly higher for White Mesa than for Sweetwater. The mill is currently on standby, but it has a license to operate.

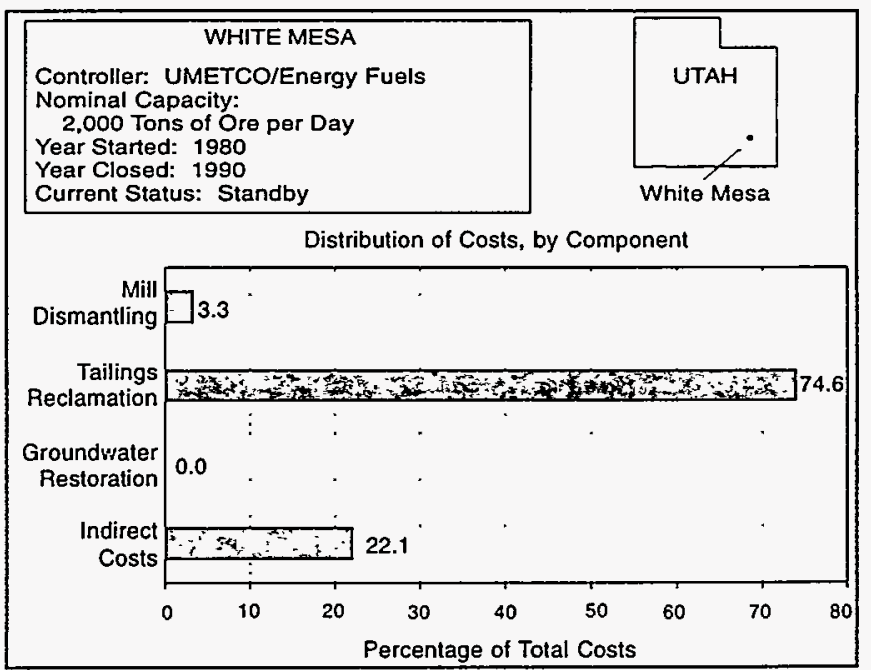




\section{'}




\section{Decommissioning of Nonconventional (In Situ Leach) Production Facilities}

\section{Introduction}

Domestic uranium production by either conventional or nonconventional (in situ leaching) methods is declining, but the substantial decline of conventional output has enabled in situ leaching to acquire the larger share of the shrinking domestic uranium market. The term "nonconventional" is applied to 17 uranium production facilities (Table 5). Nonconventional operations have a significant advantage over mills because they do not generate tailings. Although conventional and noncon- ventional facilities employ substantially different techniques to recover uranium from ore, they face some similar environmental restoration problems. For that reason, this chapter follows a format generally similar to the previous chapter, discussing the following: (1) the uranium recovery techniques used; (2) the general decommissioning process for nonconventional production facilities; and (3) gives an overview of the cost components and a summary of the status of nonconventional uranium production facilities.

Table 5. Status of Nonconventional Uranium Production Facilities as of January 1, 1994

\begin{tabular}{|c|c|c|c|c|}
\hline Name & Licensee & State & $\begin{array}{l}\text { Surety } \\
\text { (Thousand } \\
\text { Dollars) }\end{array}$ & Status \\
\hline Bruni & Westinghouse & TX & 6,131 & Wellfield restored; plant decommissioning. \\
\hline Burns Ranch/Clay West & USX (U.S. Steel) & TX & 25,030 & Wellfield undergoing restoration; plant decommissioning. \\
\hline Chris. Ranch/lrigaray & Total Minerals & WY & 8,022 & Wellfield and plant classified as operating. \\
\hline Highland $\ldots \ldots \ldots$ & $\mathrm{CCMV}^{\mathrm{a}}$ & WY & 4,821 & Wellfield and plant classified as operating. \\
\hline Hobson $\ldots \ldots \ldots \ldots$ & Everest Minerals & TX & 636 & Wellfield undergoing restoration; plant on standby. \\
\hline Holiday/EI Mesquite .. & Total Minerals & TX & 12,231 & Wellifield and plant classified as operating. \\
\hline Kingsville Dome ..... & Uranium Resources & $T X$ & 1,577 & Wellfield and plant on standby. \\
\hline Lamprecht/Zamzow . . . & Intercontinental Energy & TX & 14,050 & Wellfield in restoration; plant decommissioning. \\
\hline Smith Ranch & Rio Algom & WY & 7,500 & Both wellfield and plant classified as on standby. \\
\hline Tex-1 .... & Everest Minerals & TX & 554 & Wellifield undergoing restoration; plant decommissioning. \\
\hline West Cole & Total Minerals & TX & 3,489 & Wellfield undergoing restoration; plant decommissioning. \\
\hline Total & & & 98,392 & \\
\hline
\end{tabular}

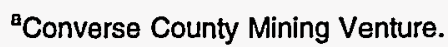

Sources: U.S. Nuclear Regulatory Commission Uranium Recovery Field Office Data Sheet, June 4, 1992. Texas Department of Health, Environmental Assessment Branch Tables of February 27, 1992 and June 5, 1992, and company data. Energy Information Administration, Form ElA-858, "Uranium Industry Annual Survey” (1993). 


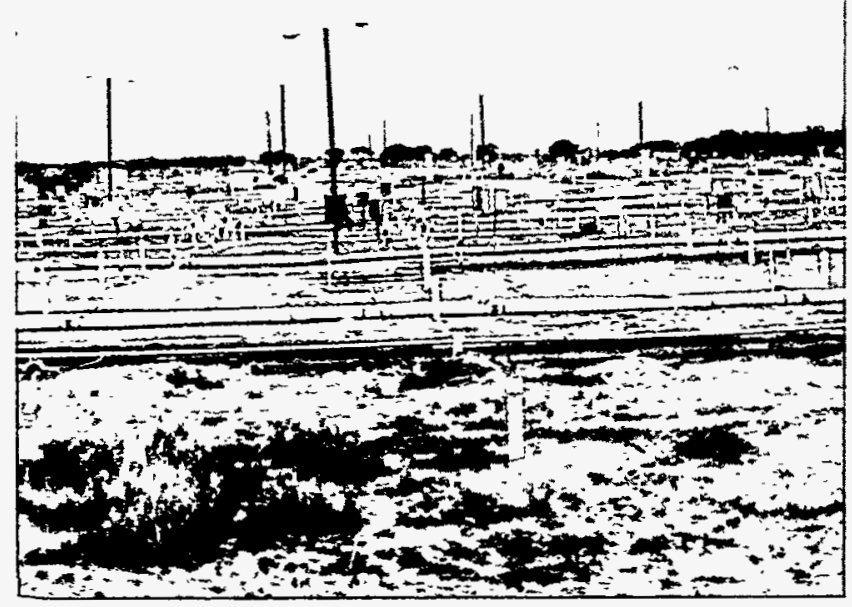

Uranium Resource's Kingsville Dome ISL wellfield located in Kleberg County, Texas, which shows a network of PVC pipes connecting injection and production wells to the $I S L$ recovery plant.

\section{Nonconventional Uranium Production Methods}

Nonconventional methods, developed as an alternative to the costly and capital-intensive method of extracting ore, can be employed in some areas neither geographically nor economically suited to traditional mining. Nonconventional operations utilize in situ leaching, a process in which barren solution and lixiviant are injected into the permeable ore zone (sand) that is confined between impermeable layers of lithologic formation (clay) ${ }^{15}$ above and below. The solution penetrates the pores in the ore, leaching out the uranium and other metals. The "pregnant" solution is then pumped up through production wells and piped to a plant where the uranium is recovered (Figure 9).

In situ leaching was first used at sites expected to present major groundwater problems for conventional mining, for sites with narrow deep ore bodies for which the expense of developing shafts and underground passages could not be justified, and shallower ore bodies for open pit mines where the cost of stripping overburden could not be justified. The in situ leaching technique in the United States is applicable to uranium deposits in permeable sandstones below the water table that are confined above and below by impermeable layers in the host-rock formation.

In the in situ leaching process in the United States, carbonate solutions normally are injected into the uranium formation through a pattern of injection wells (commonly a square pattern) and recovered through a well located in the center of the pattern. The goal is to establish a uniform solution flow from the injection well to the recovery wells while confining the solutions to the formation that contains the uranium. The recovered solution (so-called "pregnant" solution because it contains uranium) is piped to an ion exchange plant where the uranium is removed. After the uranium is removed, the solutions (so-called "barren" solutions) are reconditioned and recycled.

The spacing between wells ranges from 50 to 100 feet on each side of the injection well pattern. Monitoring wells are drilled, both within the field and around the periphery, to detect any loss of solution (excursions) from the field or the target formation. Such excursions may lie laterally within the same sand horizon or vertically, through gaps in the confining impervious beds.

In the United States, in situ leaching operations now depend mostly on the use of sodium carbonate-bicarbonate as leachant, and gaseous oxygen or hydrogen peroxide as oxidants, replacing both acid-based and ammonia-based carbonate systems. While the sodiumcarbonate-based lixiviants may be less efficient, they overcome the environmental problems associated with the acid-based systems.

Sulfuric acid systems generally achieve high yield and efficient, rapid recovery, but they also solubilize large amounts of heavy metals within the host rock and other chemical constituents that must be restored later. Ammonia tends to absorb on clays. The ammonia slowly bleeds off the clay during restoration, and therefore the system requires excessive pore volumes of fluid to remove ammonia-a costly restoration problem.

The in situ leaching technique has gradually been improved, and it is now more efficient and less expensive than conventional milling in this country. Although the applicability of the in situ leach mining method depends on the characteristics of the ore deposit, it can now be applied at some deposits previously exploitable only by conventional methods.

${ }^{15}$ Typical lithologic formation for in situ leaching in the United States. 
Figure 9. Uranium In Situ Leach Process

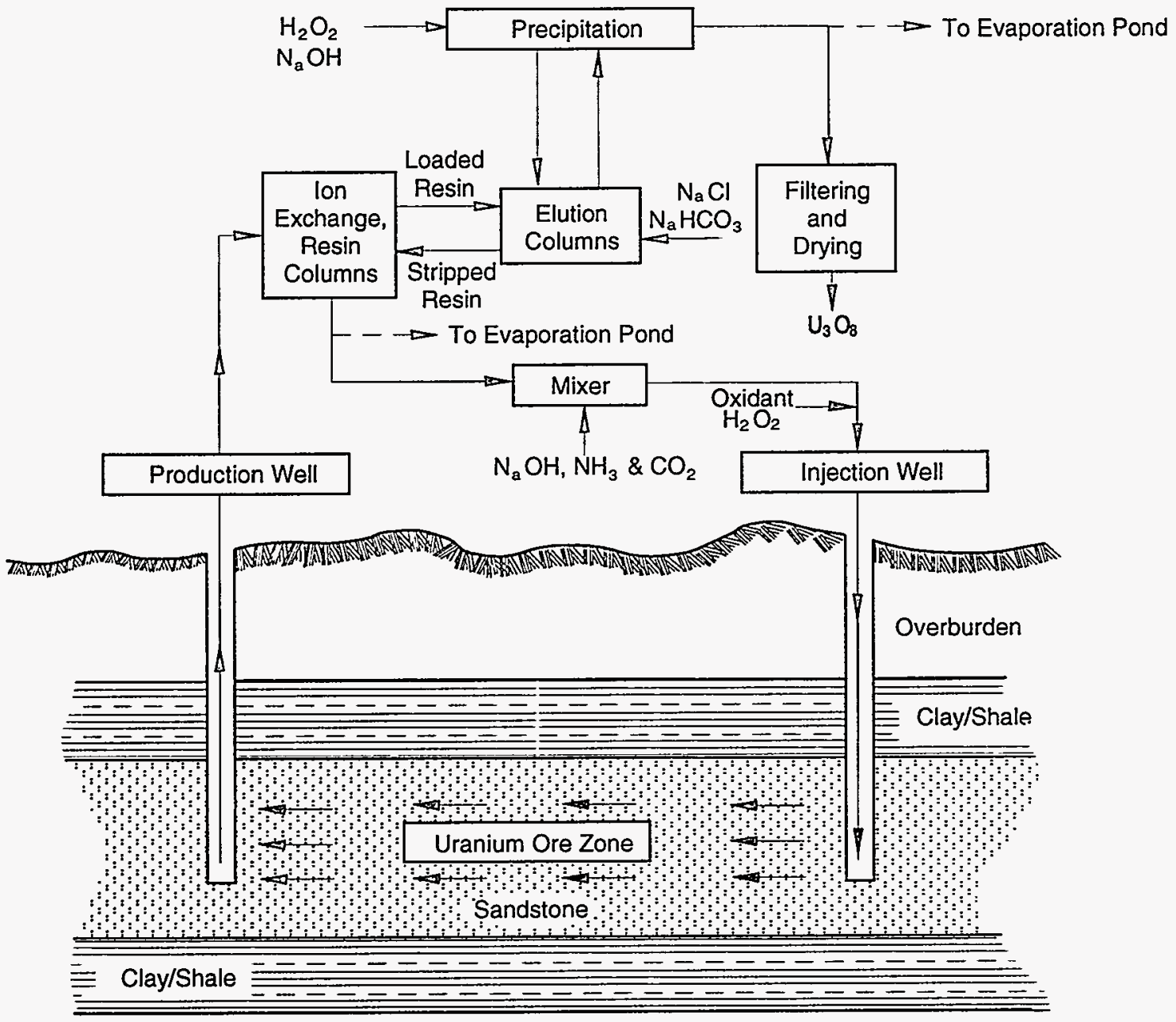

Source: Energy Information Administration, Office of Coal, Nuclear, Electric and Alternate Fuels.

The leach solutions, particularly the carbonate types, are more benign in terms of groundwater contamination, and in situ leaching creates less surface disturbance than conventional mining. In situ leaching also averts any mill tailings problem. These factors make in situ leaching more environmentally acceptable than conventional mining and milling. With the decline of conventional output, the share of total production from nonconventional operations increased to 67 percent in 1991 from 14 percent in $1980 .^{16}$

\section{The Decommissioning Process}

Decommissioning of nonconventional facilities includes decontaminating, dismantling, and removing plant facilities and wellfield equipment, site reclamation, groundwater restoration, and long-term monitoring of the site (Figure 10). In general, decommissioning in situ leaching facilities involves the following activities:

1. Dismantling and decontaminating the uranium recovery plant, disposing of equipment and materials at approved sites, and restoring.

2. Restoring the grounds-including roads and building foundations-and removing contaminated ground.

3. Cleaning groundwater in the leached zone in the sand formation by flushing it with large volumes of water, perhaps augmented by chemicals to

${ }^{16}$ Energy Information Administration, Uranium Industry Annual 1993, DOE/EIA-0478(92) (Washington, DC, October 1993). 
Figure 10. Nonconventional Production Facility Remediation Scheme

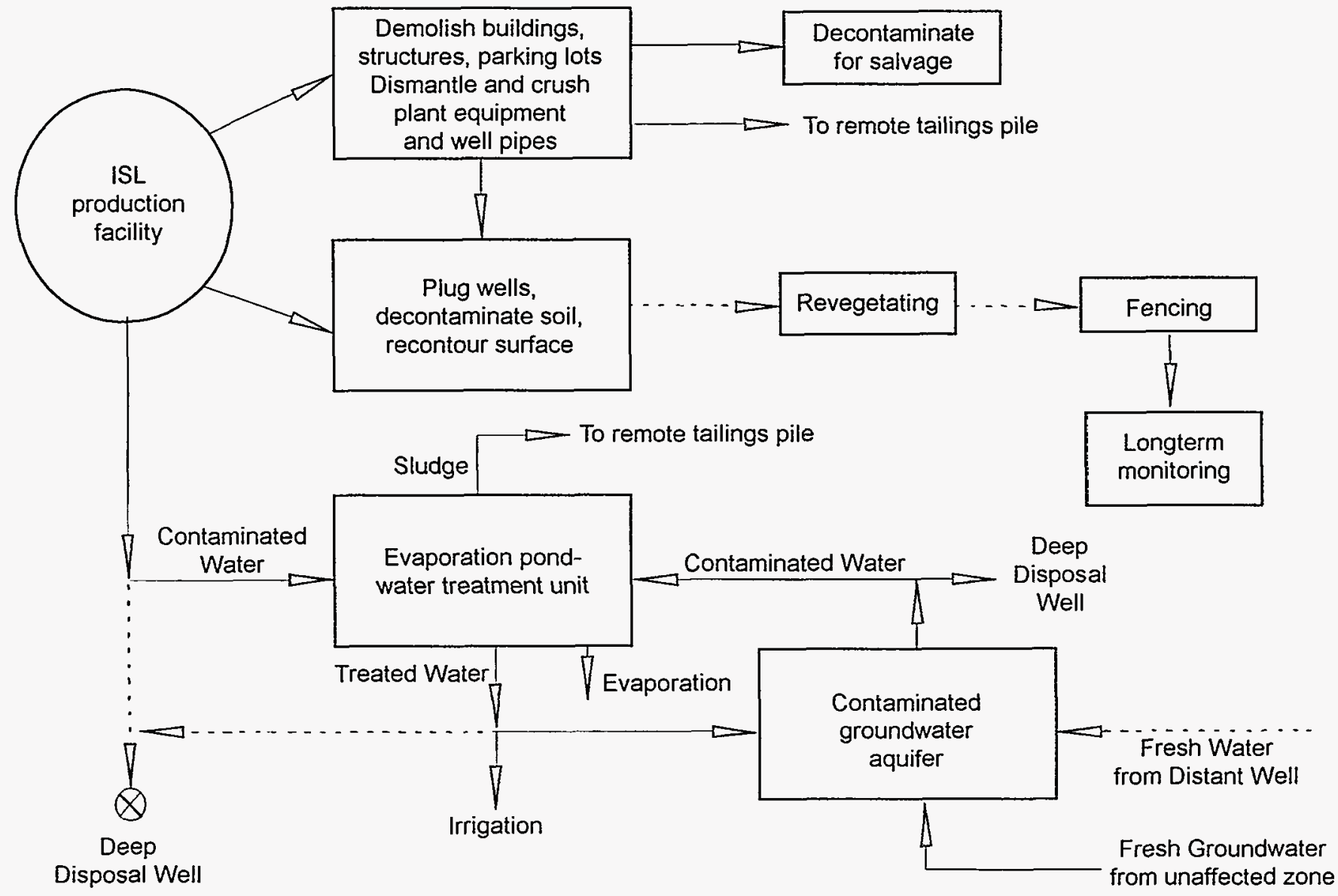

Source: Energy Information Administration, Office of Coal, Nuclear, Electric and Alternate Fuels.

stabilize formation chemistry. Original groundwater characteristics must be taken into consideration in this activity. The primary techniques of water treatment for groundwater restoration are reverse osmosis (Figure 11) and groundwater sweep (Figure 12).

4. Removing wellfield equipment, including drillhole casings, equipment, and pipes (which may already be buried) to and from the recovery plant, and related solution collection and monitoring facilities.

5. Evaporation ponds are used to dispose of waste liquids from the uranium recovery plant, from excess water recovered from the leaching field, and from groundwater restoration. Residue must go to an approved disposal site, commonly the tailings pile of a conventional uranium mill.
The priority among each component activity during the decommissioning plan is highly site-specific, therefore, the above five activities described are not in order of process. Parts of single or multiple activities can be planned concurrently as the situation dictates.

Wellfield and groundwater restoration can begin as soon as the uranium recovery phase is completed. In some cases, the groundwater restoration phase can proceed concurrently with other phases of the in situ leaching operation.

Decommissioning must also provide disposal for a variety of wastes. The process of recovering the pregnant solution during the plant's operation generates a small quantity of waste solution (in the range of 0.5 to 1.5 percent of the pregnant solution). This waste fluid is removed from the system after being processed at an ion exchange ${ }^{17}$ circuit. Similar waste fluids including

${ }^{17}$ For a definition of ion exchange, see the Glossary. 
Figure 11. Reverse Osmosis Process

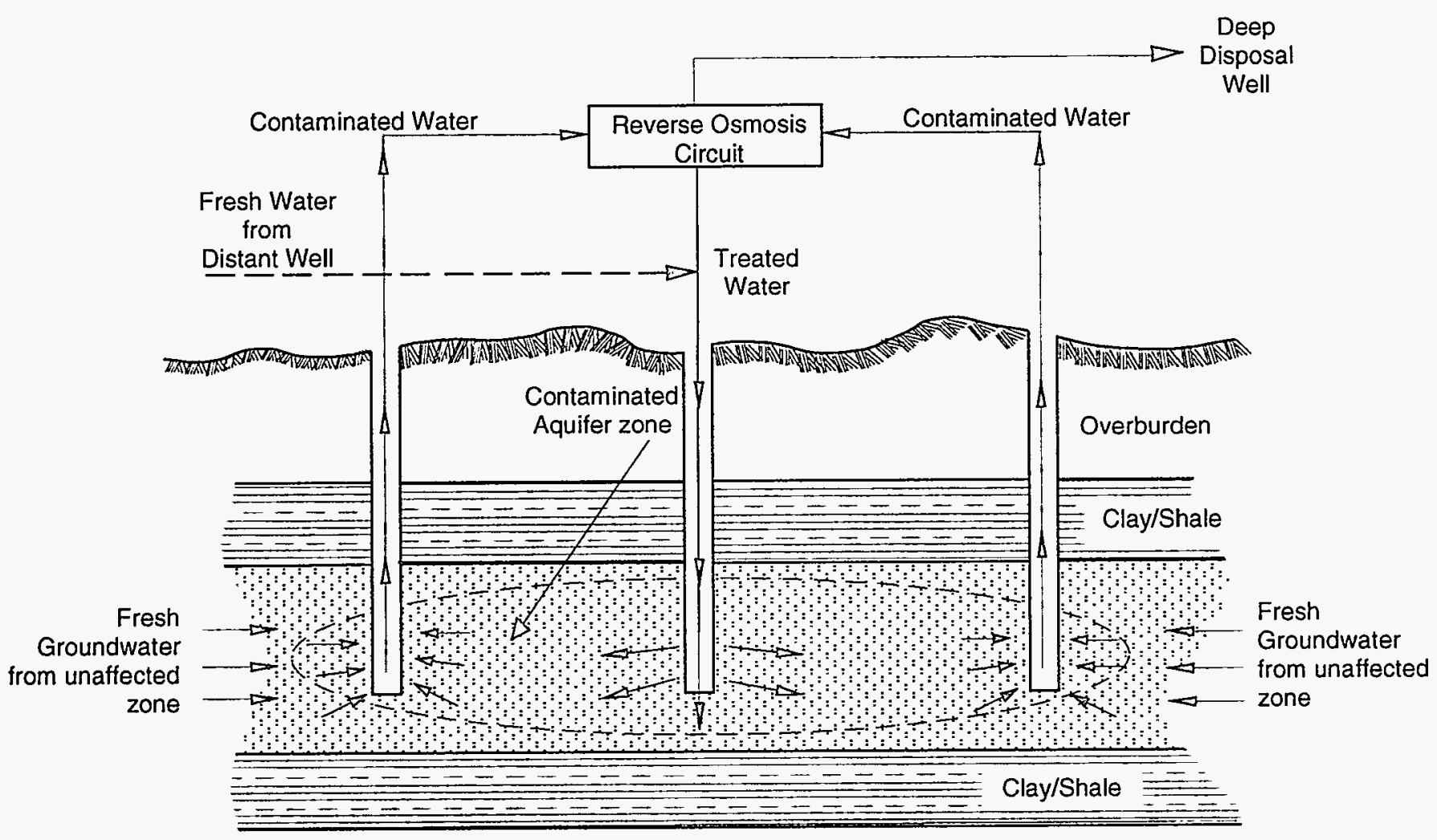

Source: Energy Information Administration, Office of Coal, Nuclear, Electric and Alternate Fuels.

bleed solution are developed in larger amounts during groundwater restoration. These fluids may be treated with barium chloride to remove the radium.

Additional waste fluids accumulate in the elution ${ }^{18}$ phase of the ion exchange operation. Additional waste solutions are also developed during yellowcake ${ }^{19}$ filtration, and from laboratory and laundry operations. These waste solutions are disposed of through evaporation or by injection in deep wells.

Small amounts of solid waste accumulate during wellfield development and operation. Larger amounts result from the decommissioning program. Noncontaminated wastes can be disposed of as normal solid wastes, but contaminated wastes, including radioactive wastes, must be disposed of at approved disposal sites.

\section{Plant Dismantling}

In general, decommissioning the plant itself involves the following five steps:

1. Decontaminating equipment and buildings for reuse if possible, and dismantling plant equipment, tanks, pipes, and facilities for disposal. This step includes cutting up and/or crushing tanks, larger equipment, and pipes and disposing of contaminated equipment at an approved site.

2. Decontaminating and dismantling buildings and foundations and disposing of contaminated materials.

3. Surveying and removing contaminated ground.

\footnotetext{
${ }^{18}$ For a definition of elution, see the Glossary.

${ }^{19}$ For a definition of yellowcake, see the Glossary.
} 
Figure 12. Groundwater Sweep Process

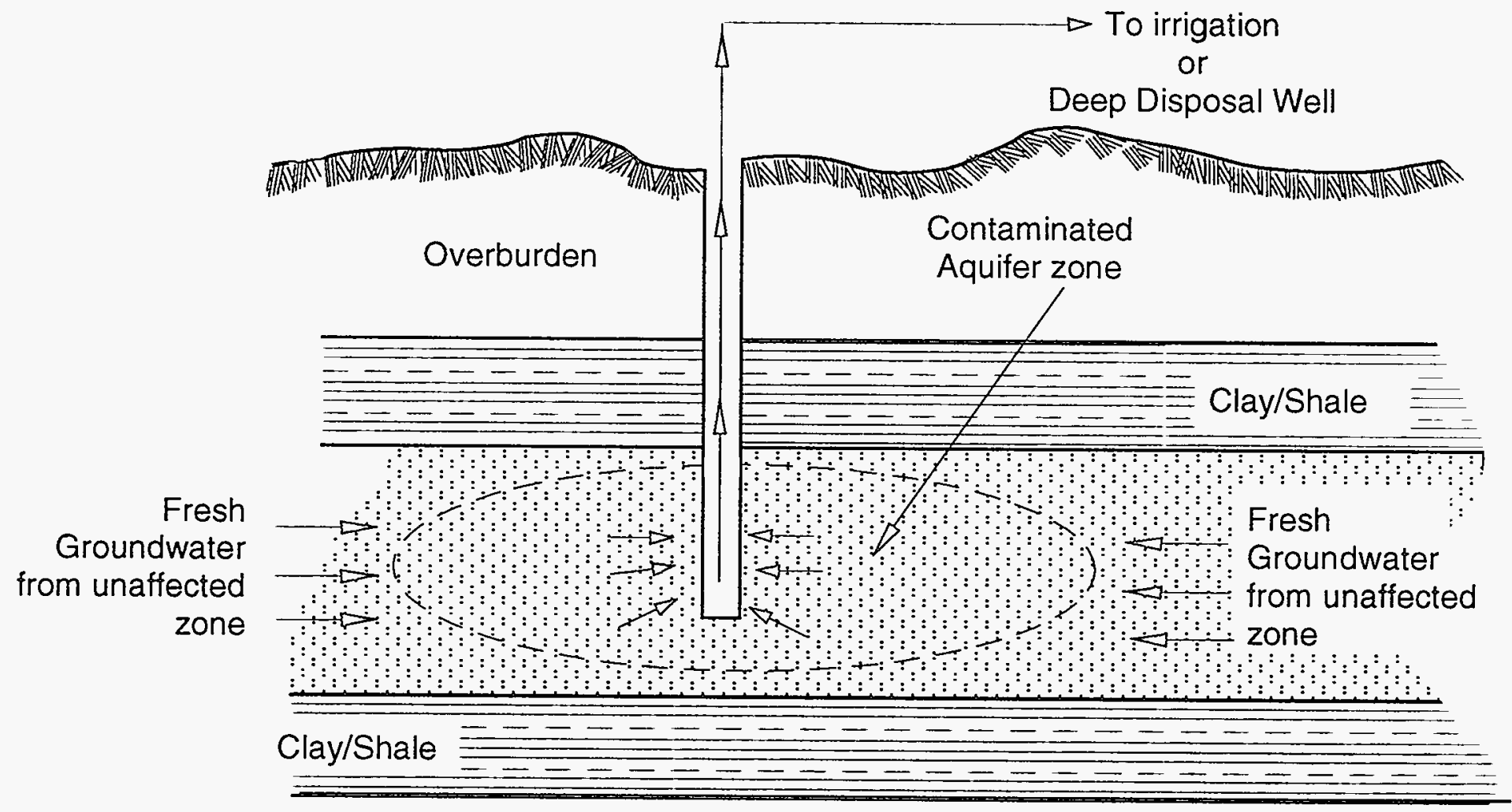

Source: Energy Information Administration, Office of Coal, Nuclear, Electric and Alternate Fuels.

4. Removing blacktopped areas, such as parking lots and roads, and ripping and regrading dirt and gravel roads.

5. Regrading, topsoiling, fertilizing, and reseeding all disturbed areas.

\section{Wellfield Restoration}

The steps involved in reclaiming the wellfield are as follows:

1. Removing solution distribution and collection piping by shredding pipes and disposing of them. This may involve trenching ${ }^{20}$ along the pipeline route.

2. Dismantling and removing other wellfield facilities, such as surge tanks, header boxes, and wellfield buildings.

3. Removing drillhole pumps and shredding and disposing of piping.
4. Plugging drillholes with drillfield "mud" or cement. Where casing is not or cannot be removed, it is cut off a few feet below the surface. The area is then backfilled and resurfaced.

5. Surveying and removing contaminated ground at wellheads, resoiling, and reseeding.

As the wellfield is restored, surface equipment can be removed. The final restoration of groundwater to NRC's standards, however, will take years. In wellfield restoration, pumps and tubing are removed from each well. ${ }^{21}$ The well is then plugged with an approved mud or cement to within about 5 feet of the surface. Casing is cut off at least 2 feet below the surface. The area is then filled, graded, and revegetated. At the request of the landowner, some wells may be retained as a water supply.

Wellfield piping recovery normally involves opening about 6-foot-deep trenches in which the pipes are buried, removing the pipe, backfilling the trenches, cutting the pipe, and loading and hauling it to the disposal

\footnotetext{
${ }^{20}$ For a definition of trenching, see the Glossary.

${ }^{21}$ Other wellfields may continue to function while some wellfields are undergoing restoration.
} 


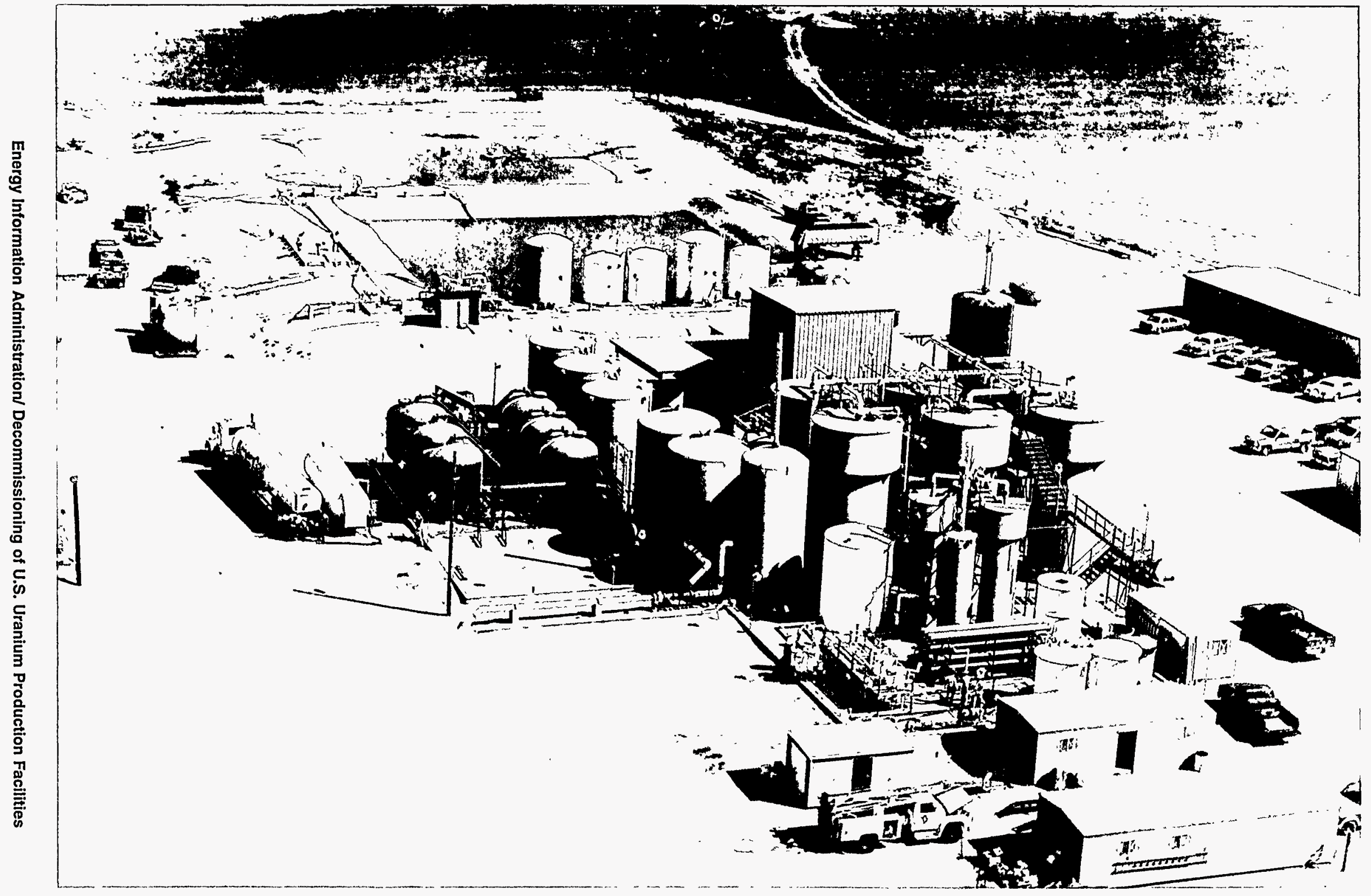

Uranium Resource's Kingsville Dome ISL plant located in Kleberg County, Texas, which shows evaporation ponds in upper portion of the photo, and the plant 
site. Wellfield electrical lines, poles, and equipment are removed. The wellfield manifold buildings are pressure-washed and dismantled. Electrical materials and wellfield buildings are disposed of in landfills.

Areas that were disturbed in the wellfield and elsewhere are recontoured, topsoiled, cultivated, mulched, and seeded for revegetation using topsoil set aside for reclamation during construction. Roads abandoned at the site are ripped up, recontoured, and restored. Depending on the site, a mixture of wheat grass, bluegrass, fescue, winterfat, and clover is used for revegetation. Areas may be fenced off until vegetation is well established. Revegetated areas are monitored for about 2 years.

\section{Groundwater Restoration}

Of the decommissioning costs for nonconventional production facilities, groundwater restoration is the major cost. Therefore, the two related activities of groundwater restoration and wastewater disposal have a significant impact on project economics.

Two widely used water treatment techniques for groundwater restoration are "reverse osmosis" and "groundwater sweep." A third method, "chemical reduction," introduces a chemical into the aquifer to precipitate contaminants. One disadvantage of this method is that it introduces another component into the system that must be removed during restoration. An example of this treatment is the use of barium chloride to precipitate radium - or the use of hydrogen sulfide for other heavy metals.

Reserve osmosis (Figure 11) is the technology most commonly used to purify the contaminated water. Groundwater is pumped out and filtered, and the $\mathrm{pH}$ is lowered to prevent calcium carbonate plugging of the membranes. The water is then fed to the unit, where it is subjected to high pressure (around $500 \mathrm{psi}$ ). The treated water (permeate) from the unit is then reinjected into the contaminated aquifer zone. The solid residue from the unit is sent to a licensed disposal pile. This method is effective, but it requires a large amount of capital and involves high operating costs.

Groundwater sweep (Figure 12) involves pumping out contaminated leach fluid and pulling in fresh groundwater from the unaffected aquifer zone. Contaminated fluid is either sent to a deep disposal well, or reinjected to the aquifer zone after treatment.
This method has the lowest cost per pore volume. Although the method is low cost, it consumes a large amount of water that must be disposed. This method may not be effective where acid or ammonium carbonates are heavily used as lixiviants.

Two major factors that must be considered during groundwater restoration are original groundwater quality and regional climate. In areas of relatively poor groundwater quality, it is easier to restore quality to baseline conditions than in areas where the quality is higher. For example, many south Texas deposits occur in aquifers with poor water quality. In Wyoming, ore zone water quality is somewhat better and may meet drinking water standards. Restoration techniques that consume less water are preferred in more arid areas, such as Wyoming and New Mexico, where regulators are more sensitive to water use. It should be noted that in situ leach mining generally consumes less water than do conventional uranium mining and milling operations.

Groundwater restoration is likely to be completed prior to decommissioning of the plant or the wellfield, thus permitting continued use of those facilities during cleanup. Procedures for groundwater cleanup are as follows:

1. Pumping an amount of groundwater from the affected leach zone equal to several volumes of the pore space ${ }^{22}$ in the zone. This groundwater may be removed by "sweeping" with surrounding natural groundwater moving into the field as the pumping proceeds and/or by injecting uncontaminated water into the field through wells. Recovered waters are processed in the uranium recovery plant and additional uranium may be recovered.

2. If necessary, reagents-including hydrogen sulfide, sodium hydrosulfide, or alkaline chemicalsmay be added to the injected solutions after a quantity of water has been pumped and while reducing conditions are being reestablished. The reagents are added to further reduce the solubility of metals in the leach zone.

3. To improve the quality of waters reinjected into the field, a "reverse osmosis"23 treatment may be needed. The cleaner water is reinjected and the remainder is sent to an evaporation pond or disposed of in deep wells.

\footnotetext{
${ }^{n}$ For a definition of pore space, see the Glossary.

${ }^{23}$ For a definition of reverse osmosis, see the Glossary.
} 
4. After adequate groundwater quality has been attained, the site must be monitored for an extended period to ensure that the conditions have stabilized and will be sustained for the indefinite future.

The cleanup of evaporation ponds can begin after the liquids are completely evaporated. The actions required are as follows:

1. Removing sludge to an approved disposal site

2. Removing and cutting pond liners

3. Removing and disposing of the leak detection piping that was under the liner

4. Refilling the pond excavation, followed by resoiling and reseeding.

When the evaporation ponds are dry, the remaining solids and the liners are removed and sent to a licensed facility (tailings pile) for final disposal. The ponds are backfilled, recontoured to blend with the natural terrain, topsoiled, and reseeded.

\section{Decommissioning Cost Components $^{24}$}

Of the 17 licensed in situ leach facilities, 1 in Nebraska and 4 in Wyoming are regulated by the NRC, and 12 are regulated by the State of Texas (Table 6). As of January 1, 1994, four facilities were classified as operating, four as on standby, and nine as either decommissioned or being decommissioned. Sureties totaling $\$ 98$ million are in effect for all 17 operations.

Cost data for 14 in situ leach projects have been compiled and combined into five categories:

1. Wellfield-dismantling of wellfield installations, ${ }^{25}$ disposal, and site reclamation

2. Plant-dismantling, decontamination, and disposal of uranium recovery facilities

3. Groundwater-flushing, treatment, and cleanup of groundwater

4. Ponds and Other-cleanup of evaporation ponds and disposal of accumulated wastes, and other costs

5. Indirect Costs-overhead costs and long term surveillance cost.
Reconciling decommissioning costs for in situ leaching operations is more complicated than for conventional mills, since the restoration of the wellfield and groundwater is an ongoing process. As a portion of the wellfield is depleted, work can begin on restoration. Thus, at any point, part of the in situ leaching project may be under development, part may be in production, and part may be in reclamation. The costs are related to the condition of the site at the time of the estimate and the condition expected over some future period. The data tabulated regarding wellfields are related to the cost estimate as much as possible.

The average cost of decommissioning of nonconventional production facilities is $\$ 7$ million, with a range of $\$ 600,000$ to $\$ 35$ million (Table 6 and Figure 13). These figures include the NRC-mandated 15-percent contingency fee and an additional 10 percent to reflect thirdparty costs. Groundwater restoration costs are the largest single item ${ }^{26}$ in all projects except Tex-1, where the total wellfield costs are slightly higher (Table 7 and Figure 14). The combined groundwater restoration costs (Table 8) for all the operations analyzed are $\$ 39.46$ million, constituting 40 percent of the total decommissioning costs.

Review of the data for these projects indicates much higher than average wellfield restoration costs for the Holiday project and the Burns Ranch/Clay West project (Table 7). Wellfield costs are influenced substantially more by factors preceding restoration than by how the land will be used afterward. The total direct decommissioning costs are significantly affected by such factors as the wellfield area, the number of wells, and the gallons-per-minute capacity of the system and the uranium recovery plant. For example, the number of wells per acre varies from 5 at the Benavides operation to nearly 39 at the Bruni site. The wellfield restoration costs per well are highest-nearly 4 times the average-at the Holiday/El Mesquite site, while the Rosita project has the lowest costs, averaging $\$ 211$ per well. Rosita, however, has one-third as many wells and acres as the average for all sites.

Groundwater restoration costs (Table 8) are influenced by the condition of the groundwater before the project begins, the quality of water available for cleanup, and the standards at which the cleanup is aimed. Areas with relatively poor groundwater quality at the site before the in situ operation will be easier than others to restore to their original condition.

\footnotetext{
${ }^{24}$ Data for this section are the most current as of January $1,1994$.

${ }^{25}$ Wellfield areas average 118 acres and contain an average of 1,200 wells.

${ }^{26}$ Neither "Ponds and Other Costs," which encompass miscellaneous costs, and "Indirect Costs," which include long-term monitoring and contractor costs, refer to a "single" activity.
} 
Table 6. Estimated Decommissioning Costs for U.S. Nonconventional Uranium Production Facilities as of January 1, 1994

(Thousand Dollars)

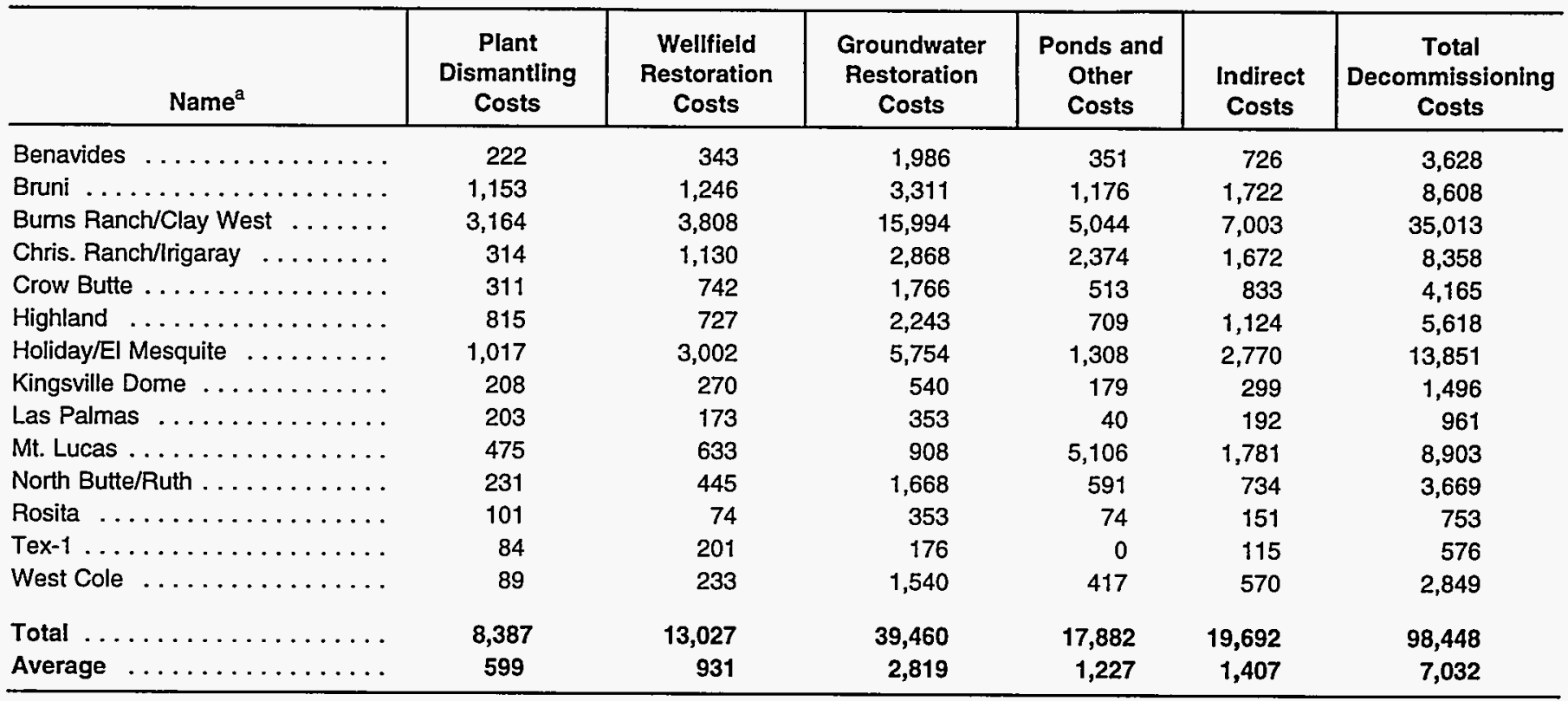

${ }^{a}$ Excludes the incomplete data for the Hobson and Lamprecht/Zamzow sites and data for Smith Ranch, a site that has not begun commercial production.

Note: Totals may not equal sum of components because of independent rounding.

Source: Table 5.

The 17 nonconventional sites are described individually in the following paragraphs.

Benavides. The wellfields at the Benavides site in Duval County, Texas, are being restored and the processing plant has been dismantled. With only five wells per acre, Benavides has the lowest ratio of any site. The groundwater costs per well are the only costs that significantly exceed the average. The estimated costs per acre (including long-term surveillance), however,

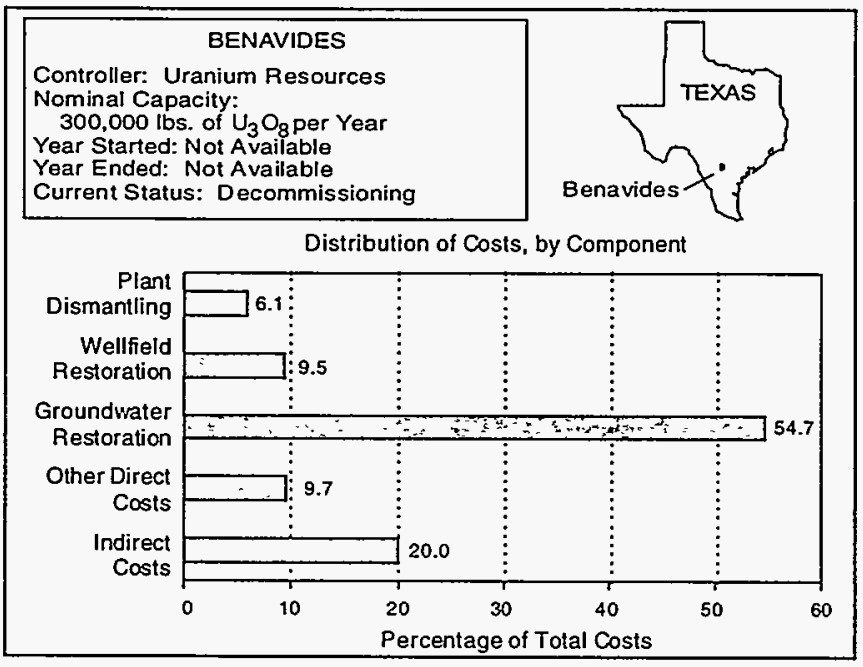

are well below average. In fact, Uranium Resources, Inc.'s Benavides operation ranks significantly below average in each major decommissioning cost category per acre: wellfield restoration, plant dismantling, groundwater restoration, other direct costs, and indirect costs.

Bruni. Decommissioning and restoration are essentially complete at Westinghouse's Bruni site in Duval County, Texas. Although the Bruni site has fewer than half as

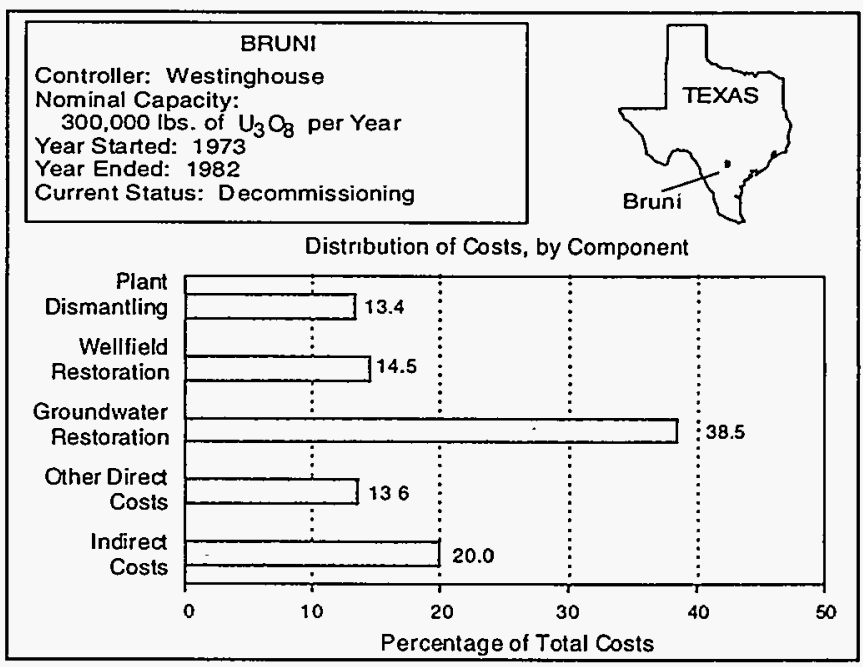


Figure 13. Estimated Total Decommissioning Costs for Nonconventional Facilities as of January 1, 1994

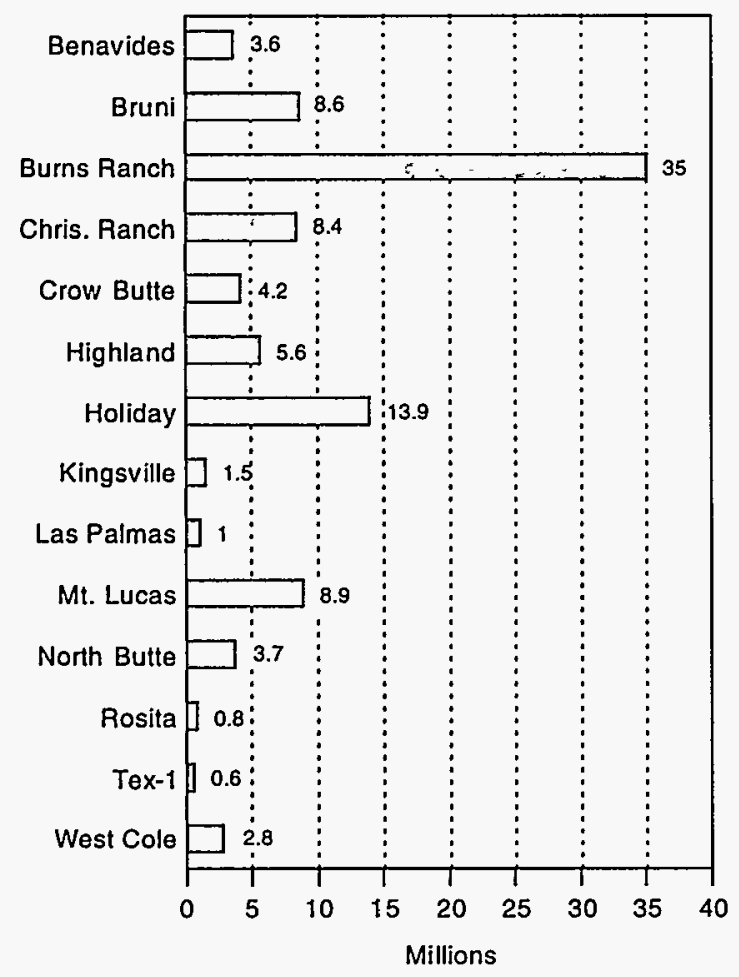

Source: Costs estimates are based on data from the U.S. Nuclear Regulatory Commission, State agencies, or companies.

many wells as Burns Ranch/Clay West, its 40-acre wellfield is among the smallest of the nonconventional sites. With nearly 40 wells per acre, Bruni's wellfield has the highest concentration of wells of any site.

Burns Ranch/Clay West. The plant in Live Oak County, Texas, has been dismantled and the wellfields and aquifers are in restoration. USX's Burns Ranch/ Clay West has the largest number of wells of any project, but the average flow rate per well is the lowest. The wellfield restoration costs are the highest of any project (Table 7), $\$ 800,000$ more than the second-ranked Holiday project, but the average cost per well for the larger wells at the Holiday project is triple the amount at Burns Ranch. Groundwater control costs (Table 8) constitute the largest category of decommissioning costs, accounting for approximately half of the project's total decommissioning costs. Although total groundwater costs are triple those of the next highest project (the Holiday site), such costs represent a slightly higher percentage of total decommissioning costs at Benavides and at West Cole.

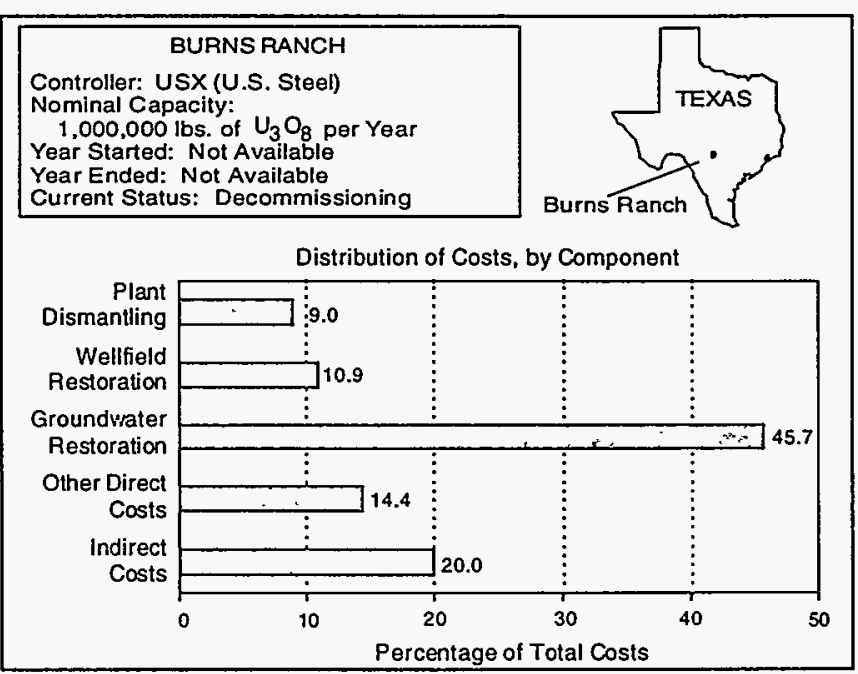

Christensen Ranch/lrigaray. The project located in Campbell County, Wyoming, is owned by Total Company and is operating. New wellfields are being developed. Christensen Ranch $^{27}$ site has the third largest wellfield area, 189 acres. The wellfield's size contributes to a higher-than-average total for wellfield restoration, but the size also contributes to a lowerthan-average cost per acre. The total for other direct costs is only slightly less than the groundwater restoration costs, the highest cost category at most nonconventional sites. It is possible that this "general" category could include costs that other companies have applied to more specific activities.

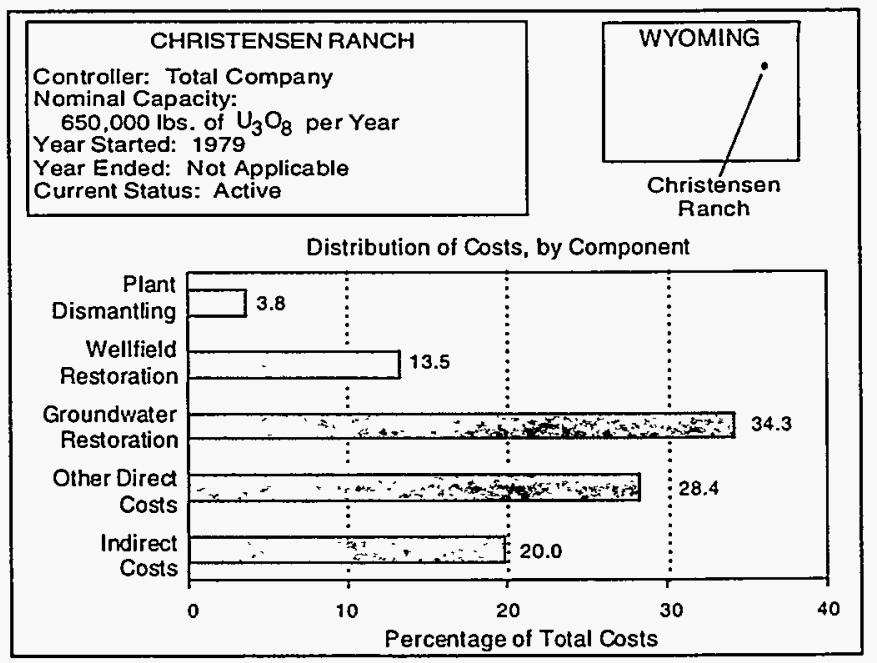

${ }^{27}$ Irigaray is the satellite wellfield facility adjacent to Christensen Ranch. 
Table 7. Estimated Wellfield Restoration Costs for U.S. Nonconventional Uranium Production Facilities ${ }^{\mathrm{a}}$ as of January 1, 1994

\begin{tabular}{|c|c|c|c|c|c|}
\hline Benavides $\ldots \ldots \ldots \ldots \ldots$ & 420 & 343 & 817 & 3,628 & 8,638 \\
\hline Bruni $\ldots \ldots \ldots \ldots \ldots$ & 1,558 & 1,246 & 800 & 8,608 & 5,525 \\
\hline Bums Ranch/Clay West ..... & 3,700 & 3,808 & 1,029 & 35,013 & 9,463 \\
\hline Highland $\ldots \ldots \ldots \ldots \ldots$ & 2,263 & 727 & 321 & 5,618 & 2,482 \\
\hline Holiday/El Mesquite $\ldots \ldots \ldots$ & 1,000 & 3,002 & 3,002 & 13,851 & 13,851 \\
\hline Kingsville Dome . . . . . . . . & 300 & 270 & 900 & 1,496 & 4,987 \\
\hline Las Palmas $\ldots \ldots \ldots \ldots$ & 344 & 173 & 503 & 961 & 2,794 \\
\hline Mt. Lucas . . . . . . . . . . . & 737 & 633 & 859 & 8,903 & 12,080 \\
\hline Total & 15,079 & 13,027 & & 98,448 & \\
\hline Average $\ldots \ldots \ldots \ldots$ & 1,077 & 931 & 864 & 7,032 & 6,529 \\
\hline
\end{tabular}

${ }^{a}$ Excludes the incomplete data for the Hobson and Lamprecht/Zamzow and Hobson sites and data for Smith Ranch, a site that has not begun commercial production.

Wellfield restoration cost per well are calculated by dividing the wellfield restoration cost by the number of wells.

Note: Totals may not equal sum of components because of independent rounding.

Source: Cost estimates based on data from U.S. Nuclear Regulatory Commission, State agencies, or companies.

Crow Butte. Crow Butte, located in Dawes County, Nebraska, is the only in situ site outside Texas and Wyoming. The site, owned by Ferret Exploration Company, is expected to continue to operate. Total decommissioning costs under the current plan are 60 percent of the average. The projected wellfield restoration costs per well, however, are estimated at $\$ 1,021$. This is the third highest total among the sites with

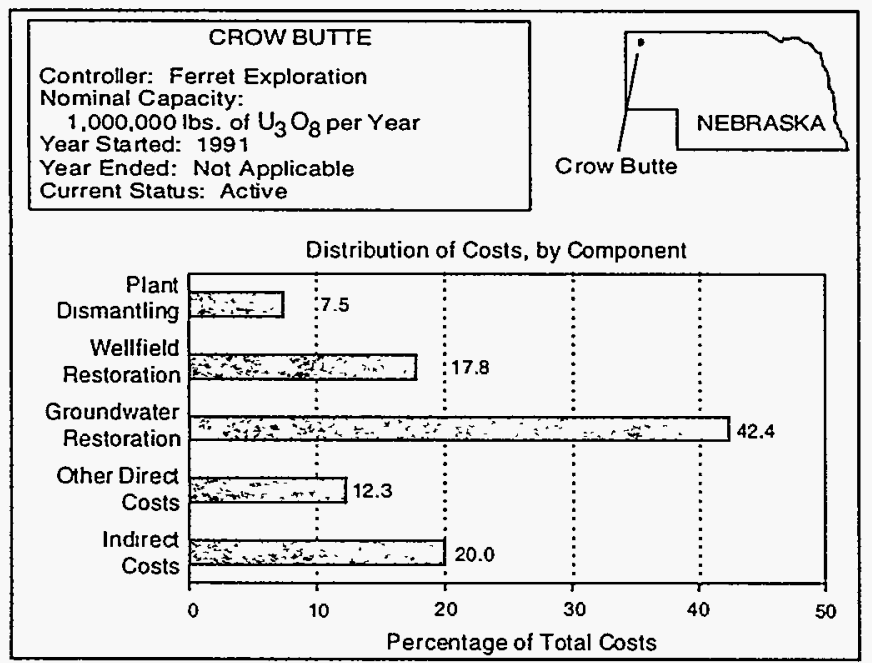

with sufficient data for analysis. The wellfield is relatively small, and this may contribute to Crow Butte's higher-than-average estimate for restoration costs per acre. Crow Butte ranks fourth in this category.

Highland. Another "Highland" site in Converse County, Wyoming, is listed in this report as a conventional site. The Highland mill (discussed in Chapter

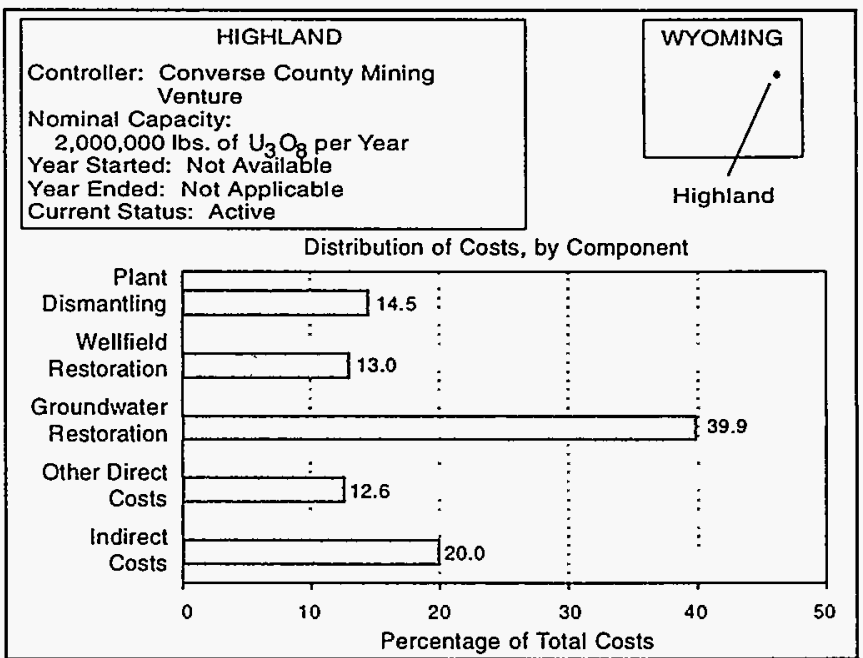


Figure 14. Major Components of Estimated Decommissioning Costs for Nonconventional Facilities as of January 1, 1994

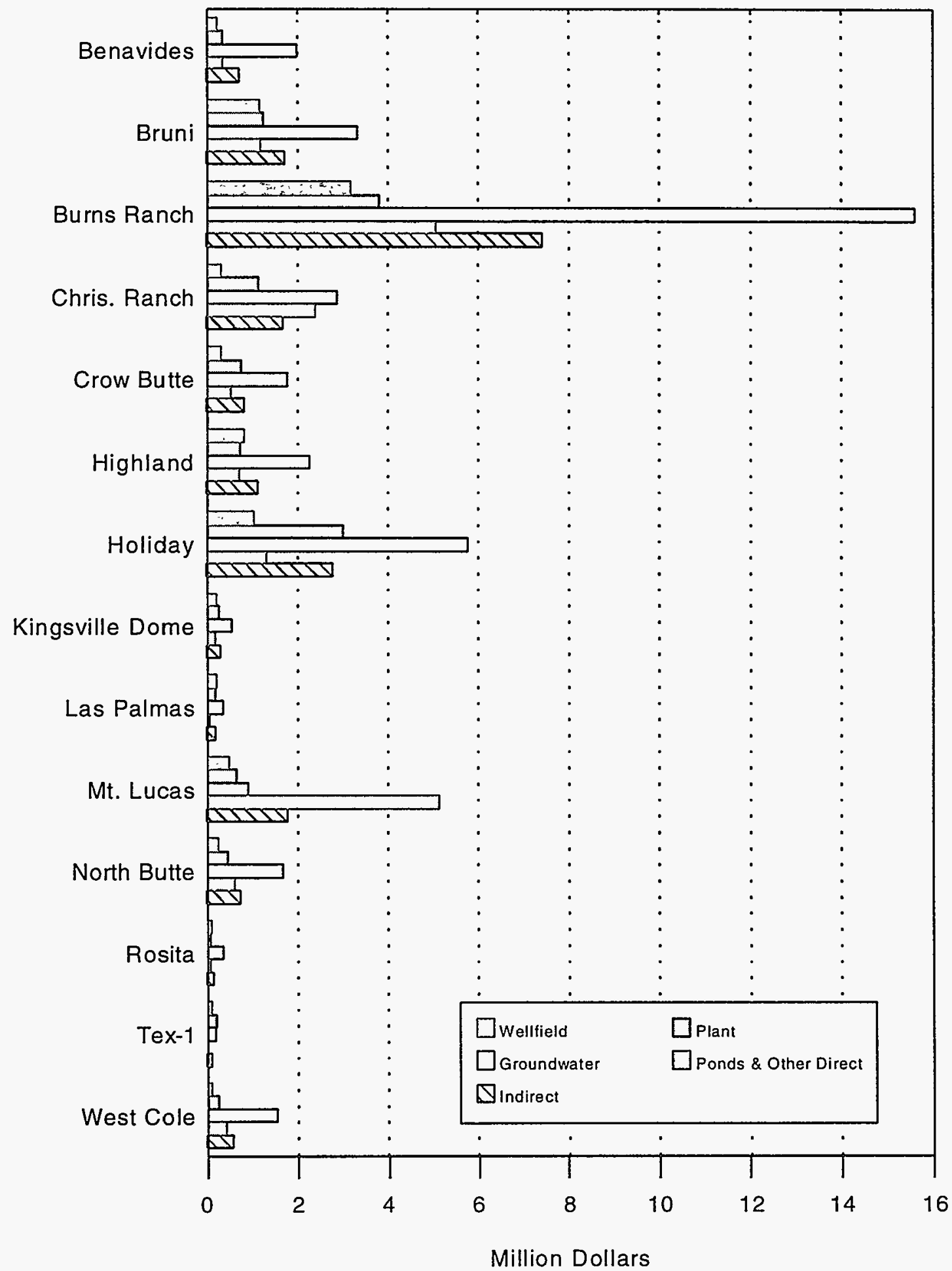

Source: Costs estimates are based on data from the U.S. Nuclear Regulatory Commission, State agencies, or licensees. 
Table 8. Estimated Groundwater Restoration Costs for U.S. Nonconventional Uranium Production Facilities as of January 1, 1994

\begin{tabular}{|c|c|c|c|c|c|}
\hline Name $^{a}$ & $\begin{array}{l}\text { Wellfield } \\
\text { Acreage }\end{array}$ & $\begin{array}{l}\text { Groundwater } \\
\text { Restoration } \\
\text { Costs } \\
\text { (Thousand Dollars) }\end{array}$ & $\begin{array}{l}\text { Groundwater } \\
\text { Restoration } \\
\text { Cost per Acre } \\
\text { (Dollars) }\end{array}$ & $\begin{array}{c}\text { Total } \\
\text { Decommissioning } \\
\text { Costs } \\
\text { (Thousand Dollars) }\end{array}$ & $\begin{array}{c}\text { Total } \\
\text { Decommissioning } \\
\text { Cost per Acre } \\
\text { (Dollars) }\end{array}$ \\
\hline Benavides $\ldots \ldots \ldots \ldots \ldots$ & 85 & 1,986 & 23,366 & 3,626 & 42,659 \\
\hline Bruni $\ldots \ldots \ldots \ldots \ldots \ldots$ & 40 & 3,311 & 82,775 & 8,608 & 215,200 \\
\hline Burns Ranch/Clay West ....... & 200 & 15,994 & 79,970 & 35,013 & 175,065 \\
\hline Highland $\ldots \ldots \ldots \ldots \ldots$ & 210 & 2,243 & 10,681 & 5,618 & 26,752 \\
\hline Holiday/EI Mesquite $\ldots \ldots \ldots \ldots$ & 168 & 5,754 & 34,250 & 13,851 & 82,446 \\
\hline Kingsville Dome . . . . . . . . . & 28 & 540 & 19,286 & 1,496 & 53,429 \\
\hline Las Palmas $\ldots \ldots \ldots \ldots \ldots$ & 51 & 353 & 6,922 & 961 & 18,843 \\
\hline Mt. Lucas . . . . . . . . . . . & 35 & 908 & 25,943 & 8,903 & 254,371 \\
\hline North Butte/Ruth . . . . . . . . . & 81 & 1,688 & 20,840 & 3,669 & 45,296 \\
\hline Total & 1,250 & 39,460 & & 98,448 & \\
\hline Average $\ldots \ldots \ldots \ldots \ldots$ & 89 & 2,819 & 31,568 & 7,032 & 78,758 \\
\hline
\end{tabular}

${ }^{a}$ Excludes the incomplete data for the Hobson and Lamprecht/Zamzow and Hobson sites and data for Smith Ranch, a site that is under construction.

Note: Totals may not equal sum of components because of independent rounding.

Source: Cost estimates based on data from U.S. Nuclear Regulatory Commission, State agencies, or companies.

2) was dismantled by Exxon, and no conventional mining is currently taking place. Converse County Mining Venture's nonconventional Highland project continues to operate near the site of the original mill.

Hobson. The Hobson plant in Duval County, Texas, is inactive. Although the wellfield has been restored, it has not yet been released by the NRC. Public documents available through the Texas Water Commission provide estimates for the wellfield restoration $(\$ 71,000)$, plant dismantling $(\$ 496,000)$, and other direct costs $(\$ 34,000)$. No estimate is available from the licensee (Everest Minerals) for groundwater restoration costs. Because the data are incomplete and possibly obsolete, the Hobson site was not included in the cost analysis.

Holiday/EI Mesquite. The Holiday/El Mesquite project situated in Duval County, Texas, is in operation. The estimated restoration costs per well are substantially higher at the Total Company's Holiday site than at any of the other sites for which data are available. The costs for the Holiday/El Mesquite project include $\$ 1.9 \mathrm{mil}-$ lion for disposal of large amounts of contaminated soil $(18,078$ cubic yards) from the wellfield, which includes a dumping fee of $\$ 110$ per cubic yard at a disposal site. Such costs apparently represent a problem unique to this site. To allow comparison of in situ leach data consistent with other plans, this portion of the amount for wellfield restoration has been removed from the Holiday/El Mesquite data.

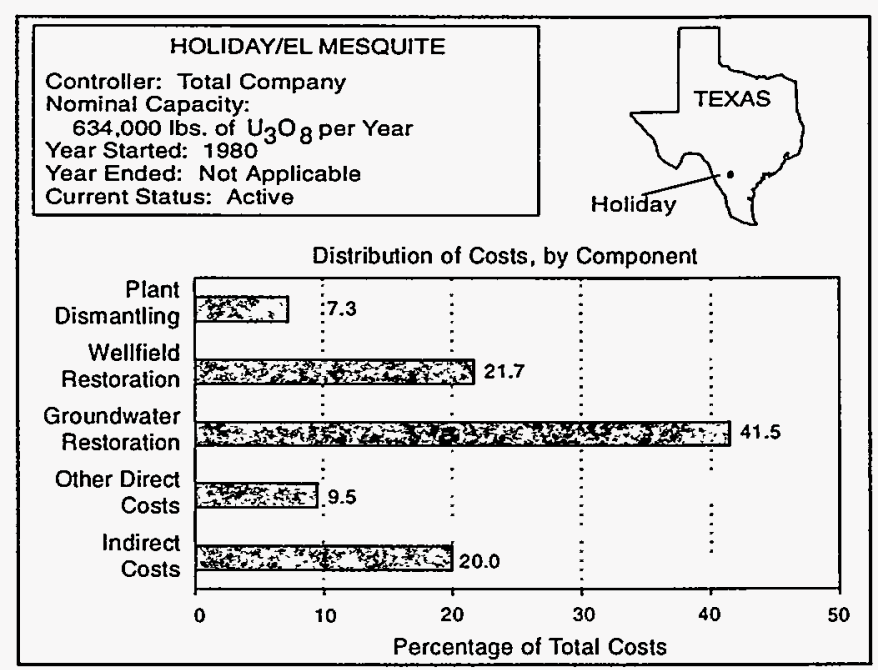

Kingsville Dome. Uranium Resource, Inc.'s Kingsville Dome located in Kleberg County, Texas, is on standby. The wellfield is among the smallest in the survey, and 
the number of wells is approximately one-third of the site average. The wellfield restoration cost per acre for Kingsville Dome is slightly lower than average, and the cost per well is only slightly higher than average. The ratio of wells to acreage is about the same as for the Highland, Rosita, and Tex-1 sites. Although the ratios are similar, the wellfield costs per well at Kingsville Dome are higher.

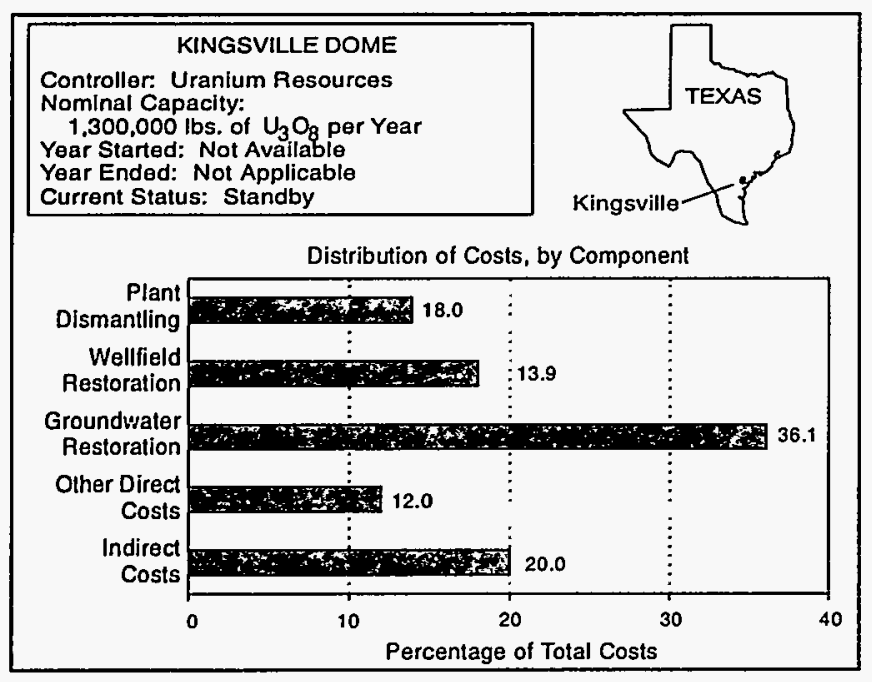

Lamprecht/Zamzow. Restoration of the wellfields and aquifer at Intercontinental Energy's Lamprecht/ Zamzow site is substantially complete. The EIA was unable to contact the company to verify certain data. Therefore, the decommissioning costs for this site are not included in the cost analysis.

Las Palmas. Everest Mineral's Las Palmas site in Duval County, Texas, has not yet been released by the NRC, but the plant itself has been dismantled and the

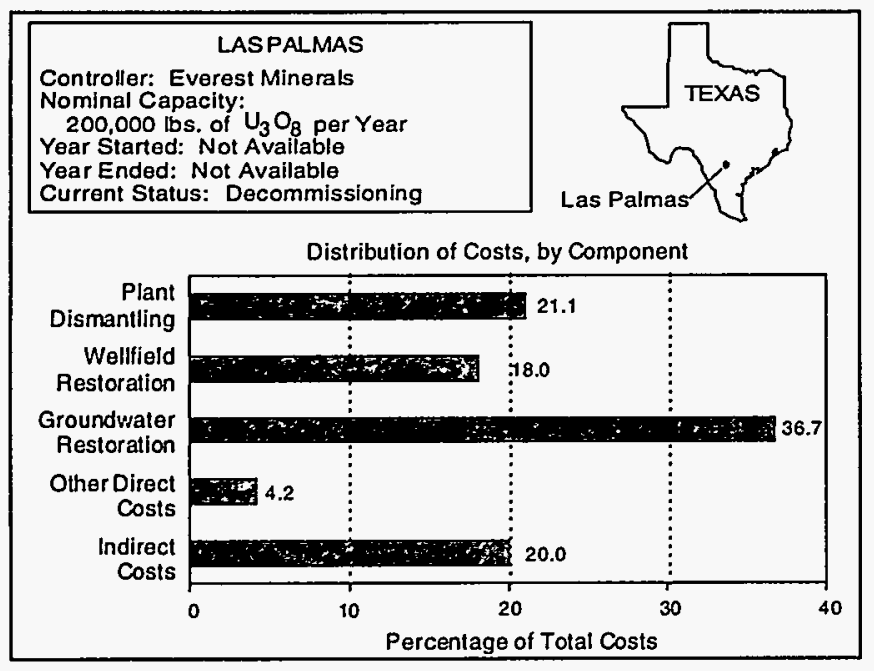

wellfields and aquifer have been under restoration. At most sites, the sum of groundwater costs and expenditures for wellfield restoration account for half or more of the total decommissioning costs. Las Palmas groundwater restoration costs and wellfield restoration costs were among the lowest. For plants with complete data, only the Rosita site had lower wellfield costs. The Hobson site was estimated to have even lower wellfield costs $(\$ 71,000)$ than either Las Palmas or Rosita, but the Hobson data were not sufficient for analysis. The decommissioning costs per acre at Las Palmas $(\$ 18,848)$ are the lowest reported for any nonconventional site.

Mt. Lucas. The wellfields at Everest Mineral's Mt. Lucas in Live Oak County, Texas, are in restoration. Because the wellfields are situated on the water reservoir of the City of Corpus Christi, the decommissioning cost per well $(\$ 12,080)$ is the second highest, next to Holiday/El Mesquite.

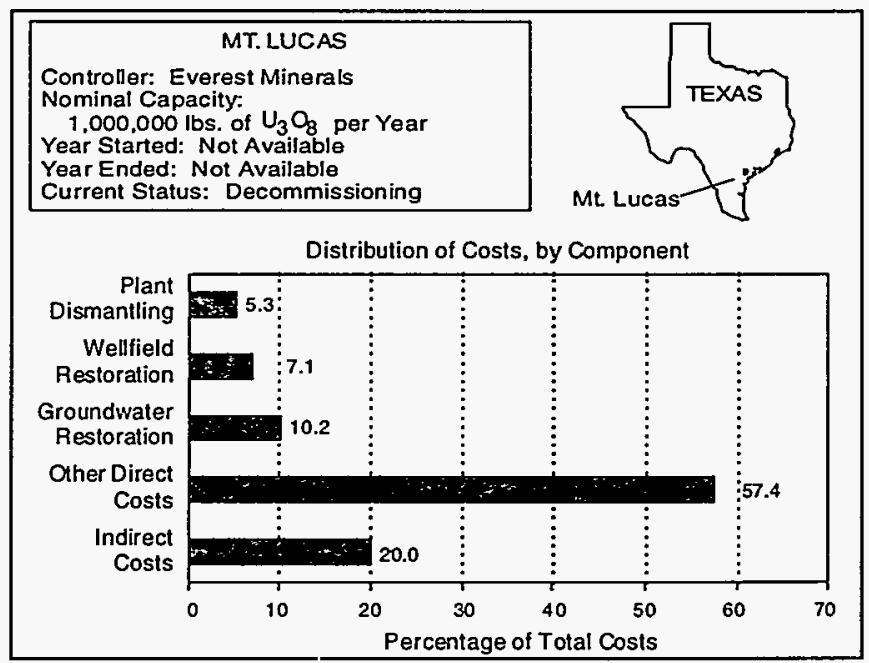

North Butte/Ruth. The decommissioning activity for Pathfinder's North Butte site in Campbell County, Wyoming, is in progress. Nearby Ruth pilot plant has been dismantled. North Butte/Ruth anticipates costs that are significantly below average. The total groundwater restoration costs ( $\$ 1.7$ million) are 60 percent of the site average ( $\$ 2.9$ million). Groundwater costs normally account for the highest expenditures at nonconventional sites. The wellfield at North Butte is virtually the same size as that at Benavides, but the ratio of wells to acreage is double that of Benavides. Generally, a higher ratio of wells to acreage is reflected in lower restoration costs per well. Benavides has an average cost per well of $\$ 817$, compared with $\$ 547$ at North Butte. The comparison, however, also illustrates a corollary that is generally true. A higher ratio of wells per acre usually corresponds to higher wellfield costs 
per acre. The wellfield costs per acre average $\$ 4,000$ at Benavides, compared with $\$ 5,500$ per acre at North Butte.

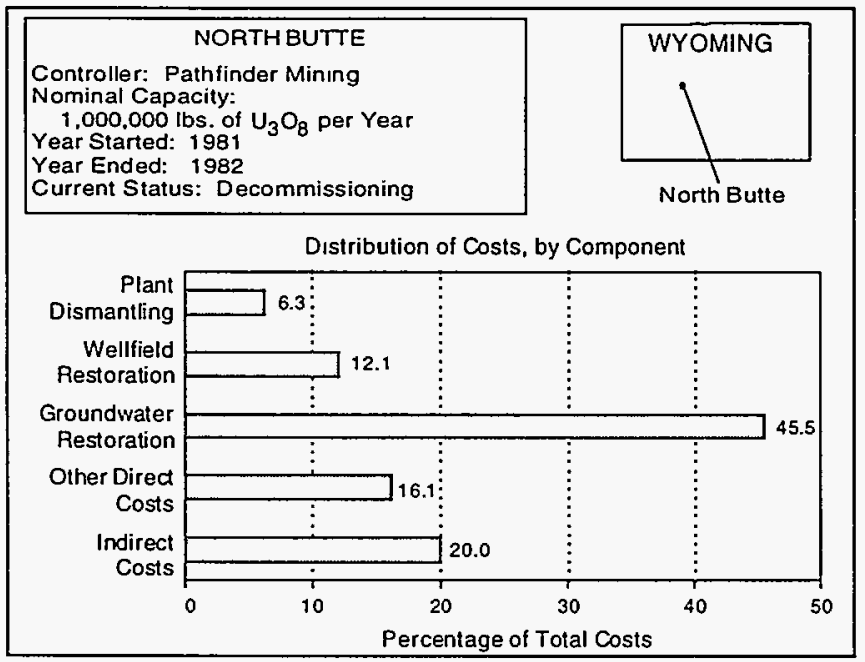

Rosita. Uranium Resources' Rosita plant in Duval County, Texas, is currently on standby. Rosita is one of the smallest sites. Among sites with complete data, Rosita's wellfield restoration costs are the lowest, less than half the costs of the Las Palmas site (next lowest in rank). ${ }^{28}$ The low cost is reflected in the site's unit cost. Dividing the wellfield total costs by the 350 wells on the property yields an average cost per well of $\$ 211$. The average cost per well for all sites is $\$ 864$. Total decommissioning costs for this operation are estimated at $\$ 0.75$ million, the second lowest total of the 14 sites analyzed.

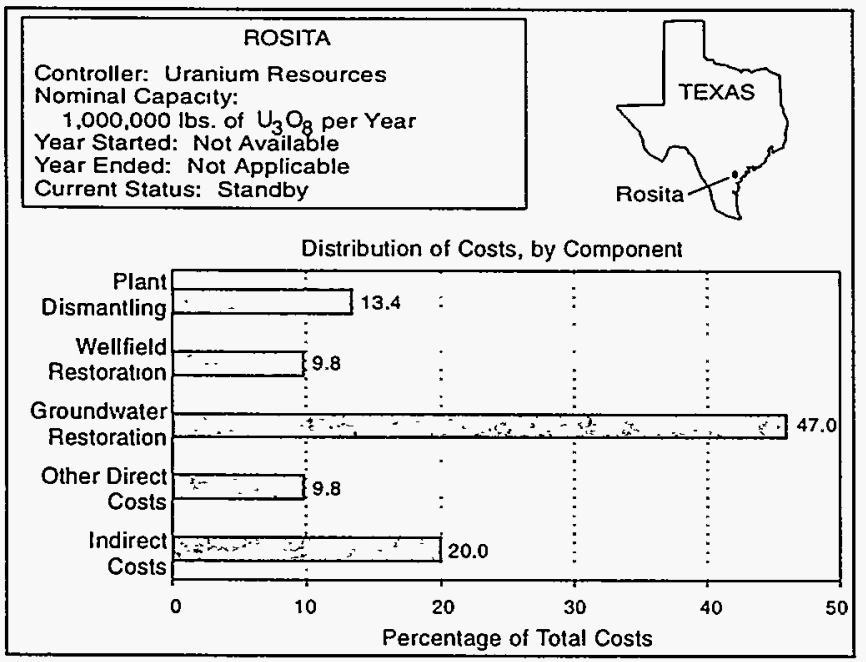

Smith Ranch. This site is still under development. Smith Ranch's decommissioning data are not included in the data tables, but the decommissioning plan developed by the Rio Algom Corporation for this site contains much useful information. Because it provides significant insight into the considerations involved in the planning stage, the Smith Ranch decommissioning plan is discussed in detail in Appendix C.

Tex-1. The total decommissioning costs for Everest Mineral's Tex-1 site are the lowest among the in situ operations with sufficient data for analysis. Groundwater costs, the leading cost category at all other nonconventional sites, account for slightly less than wellfield costs at Tex-1 and are the lowest reported. The Kingsville Dome, Hobson, and Tex-1 wellfields are nearly equal in size and are the smallest of all 17 sites. These are also the sites with the fewest wells. All the direct decommissioning costs for Tex-1 were applied to a specific activity-wellfield restoration, plant dismantling, or groundwater control. This is the only site for which no costs were identified as "other direct costs" by the licensee.

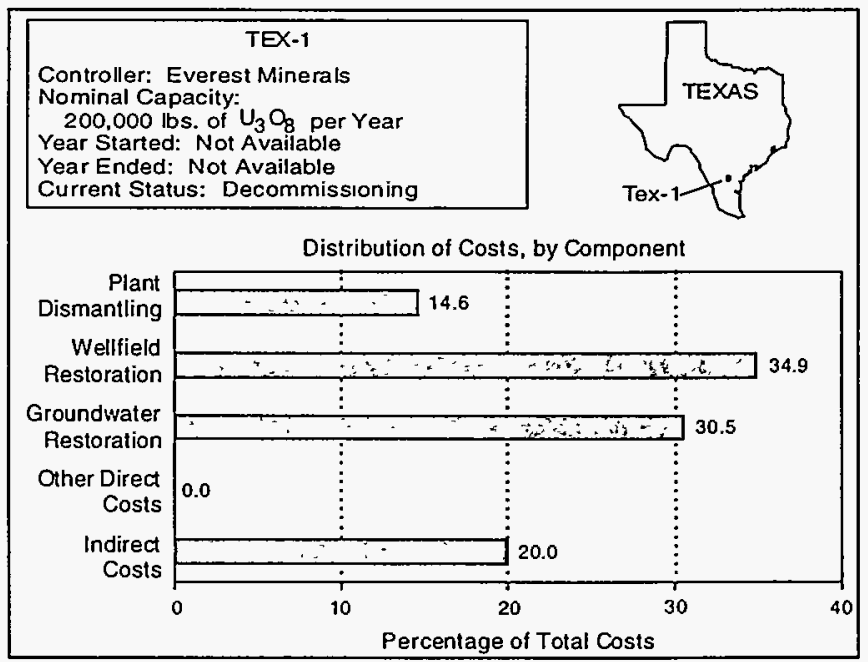

${ }^{28}$ Wellfield reclamation costs for the Hobson site, excluded from this analysis because of incomplete data, were estimated at $\$ 71,000$. If the estimate is accurate, the Hobson total is slightly lower than that for Rosita. 
West Cole. Total Company's West Cole plant in Webb County, Texas, is decommissioning. All the wellfields are either in restoration or not yet fully developed. The 47-acre wellfield at West Cole has a relatively dense population of wells, more than 600 . By comparison, the slightly larger wellfield at Las Palmas has approximately half as many wells. The cost per well is significantly lower at West Cole than at Las Palmas, but the cost per acre is substantially lower at Las Palmas.

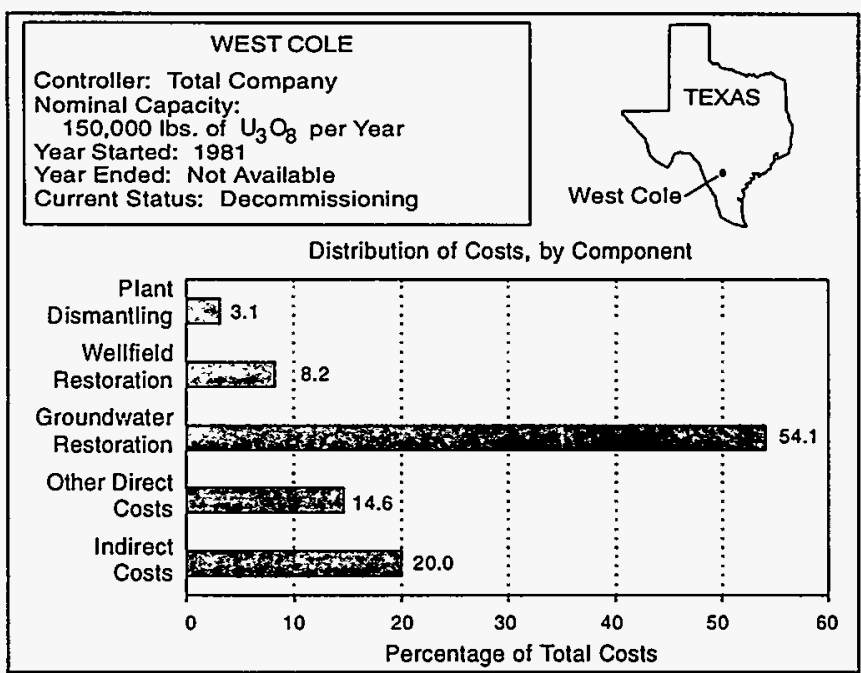





\section{Concluding Remarks}

Decommissioning of U.S. Uranium Production Facilities is not the final word on the decommissioning process. As decommissioning work progresses at various sites, authors of future reports will benefit from a wider range of specific data. Also, it was not possible to address all of the decommissioning issues (such as environmental issues, or the relationship of decommissioning costs or revenues) in this study. This report concentrates on three key elements of the decommissioning process including the plan, activities, and costs.

\section{The Decommissioning Plan}

Current regulatory procedures are now well established and understood by the industry. Plans have been developed for all facilities. These plans have been reviewéd and approved by the NRC or by the agreement States. As noted in the first chapter, however, the development of the current regulatory system was not without difficulties.

In the past, the absence of clear definition of the role of State agencies hampered regulatory control. As new laws are passed by the Congress and the States in an effort to further protect public health and the environment, the potential that State and Federal regulations will again overlap increases.

\section{Decommissioning Activities}

Experience gained by the uranium industry in decommissioning existing facilities can help to hold down costs for future sites. Regardless of how carefully a company may plan, unanticipated problems may arise when decommissioning activities are implemented. Problems might occur even after the company has completed all work described in the plan. Such unpredictable pitfalls include the following:

- Uncertain or changing criteria can hamper planning and impede an operation. For example, as State agencies re-evaluate and revise their regulations regarding mine land reclamation, the conventional uranium producer might discover that the existing plan is no longer sufficient.

- Changes in ownership of sites can lead to loss of corporate memory and thereby hamper implementing the plan. Some of the uranium processing facilities identified in this report have operated for decades. Therefore, it is reasonable to assume that some or all of the employees involved in drafting the original decommissioning plan at the time of the license application, have departed the company long before the plan was executed.

- Groundwater problems are often unpredictable. This is the one of the reasons why the tailings cover (cap) must be sufficient to prevent radon emanation and erosion of either the surface or edges of the tailings pile, and to direct drainage away from the pile. A tailings pile failure due to design defects or natural causes could allow contaminated fluid to seep into the groundwater or run off into nearby streams. The impact of unanticipated groundwater problems on costs can be substantial.

\section{Decommissioning Costs}

Decommissioning entails considerable costs for the uranium industry. The amount of surety in effect, covering costs for third parties to do the decommissioning work, totals approximately $\$ 335$ million. Of this total, \$237 million is for 26 conventional mills and $\$ 98$ million is for 17 in situ leach facilities. With the site owner doing the work, actual costs would be lower.

The average decommissioning cost for conventional facilities with sufficient data for analysis is $\$ 14.1 \mathrm{mil}-$ lion, of which over half is for tailings reclamation. ${ }^{29}$ The current generation of uranium mills is being phased out. Future operations would expect a lower rate of decommissioning costs through improved tailings pile design and groundwater restoration technology and practice.

\footnotetext{
${ }^{29}$ Costs vary from site to site, depending largely on the amount of tailings present, the design of the tailings pile, and the age of the facility.
} 
For nonconventional facilities, the average is $\$ 7$ million. Of this amount, 40 percent is for groundwater restoration. The averages for conventional and nonconventional facilities are derived from a wide data range. Decommissioning costs at some operations far exceed the average.

These costs, affecting the marginal cost of uranium production, are normally amortized over the life of the operation, and added into projected sales prices that would support developing a new plant. Therefore, decommissioning requirements would have some influence on prices, but they would not have a significant impact on future U.S. uranium production. Other costs (such as development and operating, acquisition and exploration costs) will be more influential in production decisions.

There are many uncertainties affecting the future of the U.S. uranium industry-costs, demands, future regulatory requirements. Uranium producers, however, believe there is at least one certainty: a significant increase in uranium prices would be needed to economically justify constructing new uranium production facilities in the United States. 
Appendix A

Criteria of the NRC

Performance Objectives on Mill Tailings

Reclamation 



\section{Appendix A}

\section{Criteria of the NRC Performance Objectives on Mill Tailings Reclamation}

The decommissioning plan for each uranium producing facility is adjusted to the site specific conditions, but the NRC Performance Objectives illustrate the complexity and similarity of the requirements for all sites.

NRC performance objectives for mill tailings, regulations that evolved from environmental impact studies, were established in $1977^{30}$ and are listed as follows:

\section{Siting and Design ${ }^{31}$}

1. Locate tailings so that population exposures are reduced to the minimum.

2. Locate tailings so that disruption and dispersion by natural forces are eliminated or reduced.

3. Design tailings areas so that seepage of toxic materials into the groundwater system is eliminated or reduced.

\section{During Operation}

4. Prevent blowing of tailings to unrestricted areas.

\section{Post Reclamation}

5. Reduce direct gamma radiation from the impoundment area to essentially background.

6. Reduce radon emanation to about twice the emanation rate of surrounding environs.

7. Eliminate the need for an ongoing monitoring and maintenance program following successful reclamation.

8. Provide surety arrangements to assure that sufficient funds are available to complete the full reclamation plan.
The NRC regulations most relevant to mill site decommissioning and reclamation are set out in 10 CFR Part 40, particularly in Appendix A.

The Appendix notes that license applicants for uranium mills are required to provide specifications relating to milling operations and the disposition of tailings or wastes. The Appendix establishes the technical, financial, ownership, and long-term site surveillance criteria relating to the siting, operation, decontamination, decommissioning, and reclamation of mills and tailings or waste systems. ${ }^{32}$ It notes that licensees may propose alternatives to the requirements of the Appendix that may be acceptable if the alternative would result in an equivalent or higher level of stabilization and containment of the site in order to achieve equal or greater protection to the public health and the environment.

\section{Technical Criteria}

1. The goal is permanent isolation of tailings and contaminants by minimizing disturbance and dispersion by natural forces, without ongoing maintenance.

2. To avoid proliferation of waste disposal sites and reduce surveillance obligations, wastes from in situ leaching operations, evaporation ponds, and small operations should be disposed of in existing large mill tailings sites.

3. Prime option for disposal of tailings is below grade, in mines or specially excavated pits. Where not practicable, above grade disposal programs must provide reasonably equivalent isolation of the tailings.

4. The following site and design criteria are mandatory:

${ }^{30}$ U.S. Department of Energy, Grand Junction Office Uranium Seminar Proceedings GJO-108(77) (Grand Junction, CO, Oct. 1977)

Overview of NRC Mill Licensing Activities by John B. Martin

${ }^{31}$ The tailings pile characteristics are described in Table A1.

${ }^{32}$ The constituents present in tailings pond water are described in Table A2. 
Table A1. Typical Characteristics of Uranium Mill Tailings

\begin{tabular}{|c|c|c|c|}
\hline $\begin{array}{c}\text { Tailings } \\
\text { Component }\end{array}$ & $\begin{array}{c}\text { Particle Size } \\
(\mu \mathrm{m})\end{array}$ & $\begin{array}{c}\text { Chemical } \\
\text { Composition }\end{array}$ & $\begin{array}{c}\text { Radioactivity } \\
\text { Characteristics }\end{array}$ \\
\hline Sands & 75 to 500 & $\begin{array}{l}\mathrm{SiO}_{2} \text { with }<1 \% \text { complex silicates of } \mathrm{Al}, \mathrm{Fe}, \mathrm{Mg}, \mathrm{Ca} \text {, } \\
\mathrm{Na}, \mathrm{K}, \mathrm{Se}, \mathrm{Mn}, \mathrm{Ni}, \mathrm{Mo}, \mathrm{Zn}, \mathrm{U} \text {, and } \mathrm{V} \text {; also metallic } \\
\text { oxides }\end{array}$ & $\begin{array}{l}0.004 \text { to } 0.01 \% \mathrm{U}_{3} \mathrm{O}_{8}{ }^{\mathrm{a}} \\
\text { Acid leaching } \\
26 \text { to } 100 \mathrm{pCi}^{\mathrm{2} 26} \mathrm{Ra} / \mathrm{g} \\
70 \text { to } 600 \mathrm{pCi}^{230} \mathrm{Th} / \mathrm{g}\end{array}$ \\
\hline Liquids & & $\begin{array}{l}\text { Alkaline leaching: } \\
\mathrm{pH} 10 \text { to } 10.5 ; \mathrm{CO}_{3}^{-2} \text { and } \mathrm{HCO}_{3} ; \\
\text { dissolved solids }-10 \%\end{array}$ & $\begin{array}{l}\text { Alkaline leaching } \\
200 \mathrm{pCi}{ }^{226} \mathrm{Ra} / \mathrm{L} \\
\text { essentially no }{ }^{230} \mathrm{Th} \text { (insoluble) }\end{array}$ \\
\hline
\end{tabular}

\footnotetext{
${ }^{a}$ The $\mathrm{U}_{3} \mathrm{O}_{8}$ content is higher for acid leaching than for alkaline leaching.

beparate analyses of sands and slimes from the alkaline leaching process are not available. However, total ${ }^{226} \mathrm{Ra}$ and ${ }^{230} \mathrm{Th}$ contents of up to $600 \mathrm{pCi} / \mathrm{g}$ (of each) have been reported for the combined sands and slimes.

'Particle size does not apply. Up to 70 percent of the liquid may be recycled. Recycle potential is greater in the alkaline process.

Source: Oak Ridge National Laboratory, Integrated Data Base for 1993: U.S. Spent Fuel and Radioactive Waste Inventories, Projection, and Characteristics, March 1994.
}

a. Rainfall catchment areas must be minimized to decrease erosion potential.

b. Topographic features must provide wind protection.

c. Embankment and cover slopes must be relatively flat after final stabilization. Slopes should not be steeper than $5 \mathrm{H}$ to $1 \mathrm{~V}$ and preferably should be about $10 \mathrm{H}$ to $1 \mathrm{~V}$.

d. A self-sustaining vegetative or rock cover must be established to reduce wind and water erosion to negligible levels. Impoundment cover must be contoured to avoid concentrated surface runoff. Areas that might be affected by surface runoff must be protected by rock cover (rip rap). Surrounding terrain must be evaluated to assure that no potential erosion processes cause damage to the impoundment.

e. The impoundment must not be located near a fault that could cause an earthquake that the impoundment could not withstand. f. Where feasible, the impoundment should be designed to promote deposition and to avoid erosion.

5. This criterion concerns groundwater and supplements EPA Standards of 40 CFR Part 192.

The following information should be provided by applicants: characteristics of waste solutions; characteristics of underlying soils and geologic formations and their hydraulic gradient and conductivity; quality, capacity, and uses of groundwater at the site and lining or compaction of soils underlying ore storage areas to minimize radionuclide penetration.

a. Groundwater protection programs should consider the following:

- Installation of bottom liners made of synthetic material with leak detectors or of suitable clay 
Table A2. Constituents of Tailings Pond Water

\begin{tabular}{|c|c|c|}
\hline Constituent & Acid Mill ${ }^{\mathrm{a}}$ & Alkaline Mill \\
\hline Total Suspended Solid (mg/) .. & 435 & 44.0 \\
\hline Total Dissolved Solid (mg/l) . . . . & 39,043 & 25,400 \\
\hline Conductivity ( $\mu \mathrm{mhos}) \ldots \ldots$ & 40,788 & 28,840 \\
\hline $\mathrm{pH} \ldots \ldots \ldots \ldots \ldots \ldots$ & 1.33 & 10.32 \\
\hline Arsenic $(m g /), \ldots \ldots \ldots \ldots$ & 1.870 & 5.020 \\
\hline Barium $(m g / l) \ldots \ldots \ldots \ldots$ & 0.372 & 0.100 \\
\hline Selenium $(\mathrm{mg} /) \quad \ldots \ldots \ldots \ldots$ & 0.450 & 27.88 \\
\hline Molybdenum (mg/l) $\ldots \ldots \ldots$ & 1.659 & 104.5 \\
\hline Ammonia $(\mathrm{mg} / \mathrm{l}) \ldots \ldots \ldots$ & 3.32 & 17.8 \\
\hline Sodium $(\mathrm{mg} /) \ldots \ldots \ldots \ldots$ & 549.7 & 9,292 \\
\hline Chlorine $(\mathrm{mg} /) \ldots \ldots \ldots \ldots$ & 296.8 & 1,418 \\
\hline Sulfate $(m g /) \ldots \ldots \ldots \ldots$ & 28,876 & 8,412 \\
\hline Calcium $(\mathrm{mg} /) \ldots \ldots \ldots$ & 544.0 & 60.0 \\
\hline Potassium $(\mathrm{mg} / \mathrm{l}) \ldots \ldots \ldots \ldots$ & 82.3 & 35.1 \\
\hline Bicarbonate $(\mathrm{mg} /) \quad \ldots \ldots \ldots$ & -- & 2,388 \\
\hline Nitrate/nitrite $(\mathrm{mg} /) \ldots \ldots \ldots$ & 2.03 & 10.72 \\
\hline Magnesium $(\mathrm{mg} /) \ldots \ldots \ldots$ & 1,205 & 813 \\
\hline Vanadium $(\mathrm{mg} / \mathrm{l}) \ldots \ldots \ldots$ & 56.630 & 1.18 \\
\hline Zinc $(m g / l) \ldots \ldots \ldots \ldots$ & 8.25 & $<0.25$ \\
\hline Aluminum $(\mathrm{mg} / \mathrm{l}) \ldots \ldots \ldots$ & 1,220 & $<0.25$ \\
\hline Lead $(m g / l) \ldots \ldots \ldots \ldots$ & 0.875 & 0.007 \\
\hline Cadmium $(m g / l) \ldots \ldots \ldots \ldots$ & 0.014 & 0.001 \\
\hline Gross $\alpha(\mathrm{pCi} / l) \ldots \ldots \ldots$ & $43,000 \pm 2,000$ & $3,400 \pm 400$ \\
\hline Radium-226 (pCi/l) ...... & $27 \pm 8$ & $56 \pm 17$ \\
\hline Radium-228 (pCi $/) \ldots \ldots \ldots$ & -- & -- \\
\hline Lead-210 (pCi/l) $\ldots \ldots \ldots \ldots$ & - & - \\
\hline Uranium $(m g /) \ldots \ldots \ldots \ldots$ & 11.4 & 4.17 \\
\hline
\end{tabular}

aSamples from West Borrow Pit decant, United Nuclear Corporation mill tailings, Church Rock, New Mexico.

bSamples from sump for tailings water drainage, United NuclearHomestake Partners, Milan, New Mexico.

Note: Samples, unfiltered, taken in November 1979.

Source: New Mexico Energy and Mineral Department, "Uranium Reserves and Technology: A Review of the New Mexico Uranium Industry," 1980.

- Mill process designs that recycle solutions and conserve water to reduce the amount of liquids added to the impoundment

- Dewatering of tailings by process devices and drainage systems

- Neutralization of chemicals to promote immobilization of toxic substances

- Where groundwater impacts occur due to seepage, action must be taken to reduce seepage and restore groundwater quality.

b. The groundwater restoration plan should establish groundwater protection standards. It should specify maximum concentrations of certain listed constituents at points selected to provide prompt indication of contamination on the down gradient edge of the tailings disposal areas. The listed constituents include metals such as arsenic, lead, and mercury, insecticides and herbicides, as well as radium and alpha radiation. Standards will have to be set for other hazardous substances that are expected to be in the groundwater, or which have been detected in the uppermost aquifer.

6. After the final disposal, tailings or wastes must have an earthen cover designed to control radiological hazards for a minimum of 200 years, and for 1,000 years to the extent reasonably achievable. Licensees must also limit radon-222 releases to 20 picocuries per square meter per second, averaged over the disposal area. Radon release limitation requirements apply to any portion of the disposal site unless radium concentrations do not exceed 5 picocuries per gram in the first 15 centimeters $(\mathrm{cm})$ below the surface and do not exceed 15 picocuries in layers more than $15 \mathrm{~cm}$ below the surface. Direct gamma exposure should be reduced to background levels.

7. At least 1 year before major site construction, a monitoring program must be conducted to provide baseline data on the mill site and its environs. A monitoring program must be conducted throughout the construction and operation phase to assure compliance and to evaluate impacts.

8. Operations must be conducted so that airborne effluent releases are as low as reasonably achievable. Primary control is through emission control. Where necessary, institutional controls such as extending the site boundary may be employed. To control dust from tailings, portions not covered by standing liquids must be wetted or chemically stabilized. Consideration should be given to phased covering and reclamation of tailings. Operations should be conducted to provide reasonable assurance that the annual dose equivalent does not exceed 25 millirems to the whole body to any member of the public. Daily inspections of the waste retention system must be made by qualified personnel and any failures or potential problems reported to the NRC.

9. Financial surety arrangements must be made to assure that sufficient funds will be available for the decontamination and decommissioning of the mill and site and for the reclamation of any tail- 
ings or waste disposal areas. The amount of the funds must be based on NRC-approved plans and cost estimates. The decommissioning plan must bring the site to a status that will allow unrestricted use of the mill site and reclamation of the tailings and waste areas in accordance with the Technical Criteria of Appendix A, described above. The surety amount must include funds for long-term surveillance and control, described in 10, below. The cost estimates must be based on the costs of having an independent contractor perform the work. The surety amount will be reviewed annually to consider inflation, changes in plans, work performed, and other conditions influencing costs. Financial surety arrangements may include surety bonds, cash deposits, certificates of deposit, deposits of government securities, and irreversible letters or lines of credit. Parent company guarantees may also be used.

10. A minimum charge of $\$ 250,000$ (in 1978 dollars) to cover the cost of long-term surveillance of mill and tailings sites must be paid prior to termination of the license. This charge may be higher if a particular site is found to have significantly greater requirements. Prior to payment, the charge will be adjusted for inflation annually using the Consumer Price Index.

11. Prior to license termination, title to the land used for disposal shall pass, without cost, to the United States government, or to the State, including land needed to ensure long-term stability.

12. Final disposition of tailings and wastes should not require ongoing maintenance to preserve isolation. Inspections of the site shall be made at least annually to confirm the integrity of the pile and to determine the need for maintenance work. The
NRC may require more frequent inspections at particular sites.

13. EPA identifies approximately 375 hazardous substances for which standards must be set if anticipated or detected in groundwater.

To assist the industry in conforming to the regulations, additional guidance has been provided by the NRC. This includes:

1. Guidelines for Decontamination of Facilities and - Equipment Prior to Release for Unrestricted Use or Termination of Licenses for Byproduct or Source Material ${ }^{33}$

2. Recommended Outline for Site Specific Reclamation and Stabilization Cost Estimates

3. Design of Erosion Protection Covers for Uranium Mill Tailings Sites

4. Standard Format and Content of Decommissioning Plans for Licensees Under 10 CFR Parts 30, 40, and 70 (Regulatory Guide 3.64)

5. Calculation of Radon Flux Attenuation by Earthen Uranium Mill Tailings Covers (Regulatory Guide 3.65).

The EPA has overall responsibility for establishing environmental standards and guidelines. Applicable EPA standards are contained in part in 40 CFR Part 192, "Health and Environmental Protection Standards for Uranium and Thorium Mill Tailings," particularly in Subpart D. The standards in Subpart $D$ became effective December 6, 1983. However, these facilities are regulated in accordance with NRC and "agreement" State regulations under 10 CFR Part 40, "Domestic Licensing of Source Material."

${ }^{33}$ For a definition of source material, see the Glossary. 
Appendix B

Decommissioning Plan for a Mill Site 
, 


\section{Appendix B \\ Decommissioning Plan for a Mill Site}

To illustrate the expenses and procedures necessary to decommission a conventional mill, the detailed decommissioning plan developed for the Homestake Mining Company's Grants mill in New Mexico is presented in Table B1. This particular plan was selected as an example because of its thoroughness and the timeliness of the data.

The Homestake mill began operating in February 1958-nearly two decades before the NRC was created and long before decommissioning plans became a part of the licensing application-and closed in 1990. It is located north of Grants, New Mexico, on the road leading from the Ambrosia Lake mining district, the primary source of ore for the mill. The Homestake mill is actually a consolidation of two separate mills built next to each other. When it was operating, its rated capacity was 3,400 tons of ore per day. During the earlier years of operation, grades of processed ore were about 0.22 percent $\mathrm{U}_{3} \mathrm{O}_{8}$, but lesser-grade ores were processed in later years. The mill incorporated Pachuca tanks ${ }^{34}$ for pressure leaching, while relying on an "alkaline leach" process using caustic soda precipitation.

Two tailings piles, together containing about 22 million tons of tailings, are present at the site. The larger tailings pile is roughly rectangular, about 3,900 feet long and 1,900 feet wide. It stands over 80 feet high and covers about 170 acres. Side slopes have a ratio of 2 horizontal $(\mathrm{H})$ to each 1 vertical $(\mathrm{V})$ measurement. The pile is unlined; it lies on the surface, resting on relatively permeable materials. Seepage is collected in down-gradient wells for recycling to the ponds. The EPA asserts that leachate from the tailings has contaminated a shallow aquifer that serves nearby residential subdivisions. The smaller pile covers about 45 acres but otherwise has characteristics identical to those of the larger pile.

The Homestake decommissioning plan, submitted to the NRC in October 1990, provides a description of and cost information on the phases of work to be done
(Table B1). The total cost for purposes of financial surety is estimated to be nearly $\$ 20$ million. The following is an outline of that plan.

\section{Mill Dismantling}

Decommissioning of the Grants mill will be accomplished in the following stages:

- Buildings and equipment will be demolished and buried on site. No salvage is anticipated. The demolition of the building will take place in four steps:

1. Removal and disposal in the tailings pile of large incompressible equipment, such as motors

2. Disassembly by torch-cutting of tanks, ball mills, kilns, and other large components

3. Demolition of mill structures, crushing, and removal of demolition debris

4. Filling and covering of demolition debris area to a depth of at least 2 feet, and contouring to limit runoff.

- Radiological health and safety procedures in effect will be supplemented and modified as necessary.

- Asbestos will be removed and radioactive materials decontaminated before equipment is removed and building demolition begins. Asbestos will be removed from the facility and then buried at the site.

The process of restoring contaminated areas includes excavation of the contaminated soil areas to an average depth of 6 inches, as necessary, to meet regulatory requirements. The ore pad area also is expected to require excavation to a depth of 2 to 3 feet. Excavated materials will be placed at the toe of the outslope of the tailings piles prior to placement of cover.

\footnotetext{
${ }^{34}$ For a definition of Pachuca tank, see the Glossary.
} 
Table B1. Distribution of Decommissioning Cost Components for a Conventional Mill (Thousand 1991 Dollars)

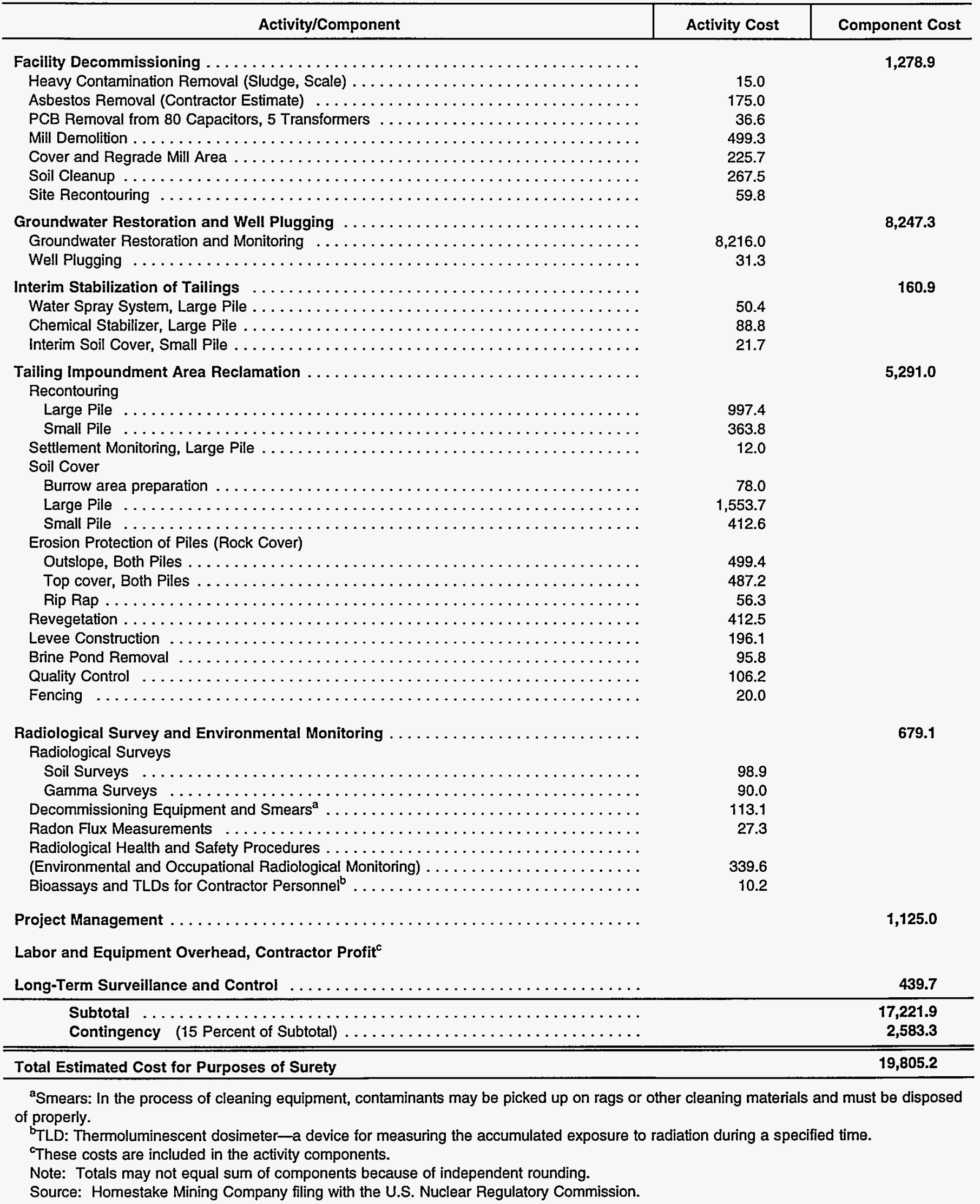




\section{Groundwater Restoration}

The groundwater restoration costs were estimated to total almost $\$ 8.25$ under the plan (Table B1). Public documents reveal how this total was derived: Grants mill groundwater restoration and monitoring (including well plugging) are estimated to cost $\$ 632,000$ per year for 7 years and $\$ 474,000$ per year for subsequent years. Bentonite will be used to plug 185 shallow wells, and concrete will be used in 2 deep wells; the cost is estimated to be $\$ 31,000$. A lined evaporation pond will be constructed on the small tailings pile for disposal of recovered groundwater. This evaporation pond will be reclaimed with the tailings pile.

\section{Interim Tailings Stabilization}

The large tailings pile is expected to be dry 9 months after startup of the evaporation pond. The dry, exposed tailings will be stabilized by a combination of water spray and chemical stabilizer. Areas exposed in the small pile outside of the evaporation pond will be stabilized with a cover of at least 0.5 feet of native soil. Costs for a water spray system, chemical stabilizer, and interim soil cover total $\$ 161,000$.

\section{Tailings Reclamation}

Total costs for tailings reclamation are estimated at $\$ 5.29$ million. Recontouring will be done by cut and fill to produce a ratio of $5 \mathrm{H}: 1 \mathrm{~V}^{35}$ outslopes and top surface gradients of not more than 4 percent with a gradually sloping ridge line. This will be done by pushing dikes and beaches into the pond basins and cutting and filling the tailings to shape the outslopes and top surfaces. For the large tailings pile, this requires the movement of about 1.8 million cubic yards of soil at an estimated cost of $\$ 997,000$. For the small pile, the cost of recontouring is estimated at $\$ 364,000$.

Settlement checkpoints will be established on the top surface. Settlement of the soil under the pile will be monitored monthly at up to 40 points for at least 2 years, or until the settlement rate has decreased to insignificant levels. The cost to monitor settlement is $\$ 12,000$.

Soil cover for the radon barrier will be a tested clay, 0.5 to 1 foot thick, covered by 1 foot of alluvial sand. This will be compacted to 95 percent maximum dry density in accordance with existing standards. ${ }^{36}$ Covering is estimated to require 274,500 cubic yards of each material at an estimated cost of $\$ 1.55$ million. Burrow areas are at haul distances of 500 to 3,000 feet. To reestablish vegetation, approximately 750 acres of ground surfaces and burrow areas will be resoiled and reseeded at a cost of $\$ 413,000$.

Existing ponds will be reclaimed by removing the liner to the tailings pile and filling the pond basins with soil from the containment dikes. The small tailings pile that houses the evaporation pond will operate for 10 to 15 years, by which time the pile will be reclaimed in the same manner already used for the large pile, recontouring and covering with 1 foot of clay and 1 foot of sand. This will require approximately 146,000 cubic yards of material costing $\$ 413,000$.

For erosion protection, the outslope will be covered with 8 inches of rock, and the top will be covered with 6 inches of rock. About 10,000 cubic yards of rip rap will be placed along 1,400 feet of the west side toe and 2,100 feet of the north side toe of the large pile. The rip rap will be 12- to 24-inch basalt rock placed to a height of 11 feet above the bottom of the outslope or above peak flood level. Scour protection ${ }^{37}$ will be provided by a rock-filled trench, 6.5 feet deep by 8 feet wide. Rock will come from a quarry 1.5 miles west of the large pile. A surface water diversion levee with a 15foot wide crest and $10 \mathrm{H}: 1 \mathrm{~V}$ sideslopes will be constructed on the east side of the large pile.

A quality control program will be established to assure that the covering materials over the tailings and mill area comply with the design specifications. The program will be an extension of the environmental monitoring and occupational radiological monitoring practiced during operation of the mill. It will include radiation safety training, security, and hazard control. A bioassay and thermoluminescent dosimeter monitoring program will be conducted. A complete record of samples and test results will be maintained.

The restricted area will be enclosed by a three-strand barbed wire fence, 19,500 feet in length. Pre-enclosure radiological surveys have been made. Post-enclosure surveys using a 10-meter grid will be conducted to verify cleanup of contamination. Radon emanation through the tailings cover will be measured by the charcoal canister system, using 100 canisters per pile.

\footnotetext{
${ }^{35}$ The ratio is the number of horizontal units (feet, meters, yards, etc.) that the pile must have in width (as a minimum) for each comparable unit of height.

${ }^{36}$ American Society for Testing Materials, ASTM Designation D-698.

${ }^{37}$ For a definition of scour protection, see the Glossary.
} 
, 
Appendix C

Decommissioning Plan for an In Situ

Leaching Site 


\section{Appendix C}

\section{Decommissioning Plan for an In Situ Leaching Site}

The decommissioning plan prepared by Rio Algom for the Smith Ranch in situ leaching facility (Table C1) has advantages similar to those of the Grants mill plan (Appendix B) and is therefore presented for analytical purposes. The data are reasonably detailed, current, and comparable with data of other in situ leach facilities.

The plan was presented in documents filed with the NRC between 1988 and 1992 to support the application for a license. ${ }^{38}$ The BLM, reflecting its responsibility for Federal land tracts, assisted the NRC in preparing a draft Environmental Assessment. ${ }^{39}$ A notice of the draft, "Finding of No Significant Impact," was published in the Federal Register on October 28, 1991. No comments were received during the public comment period. A Safety Evaluation Report was also prepared by the NRC. ${ }^{40}$ The following summary is derived from those documents.

The objective of the decommissioning plan is to return the surface and groundwater to conditions suitable for uses that are equal to or better than those that prevailed before the operation. The main reclamation effort concerns groundwater restoration. Impacts from the wellfield operation on surface areas requiring reclamation are expected to be comparatively minor. The processing plant and evaporation ponds will require some additional efforts to decommission (such as recountouring and revegetating), but they are expected to be manageable.

Rio Algom's estimated costs (Table 7) for the various phases of reclamation relate to an area of 150 acres. Because the reclamation work will proceed as the mining units are completed, the cost estimates (made for purposes of bonding) are related to the period of the license, the expected disturbances, and the potential restoration needs.

The total estimated cost for reclamation is $\$ 5.7$ million, of which $\$ 3.9$ million (68 percent) is for groundwater cleanup. At the projected plant capacity, 10 million pounds of $\mathrm{U}_{3} \mathrm{O}_{8}$ would be produced over a 5-year period. With the addition of the 25-percent contingencies and third-party costs, the estimated decommissioning cost per pound is $\$ 0.71$.

\section{Wellfield Restoration}

In well field restoration, pumps and tubing are removed from each well. The well is then plugged with an approved mud or cement to within five feet of the surface. Casing will be cut off at least two feet below the surface. The area is then filled, graded and revegetated. Some wells may be retained at the request of the land owner as a water supply.

Wellfield piping recovery involves opening of the six feet deep trenches in which the pipes are buried, removing the pipe, backfilling the trenches, cutting the pipe, loading and hauling to the licensed Hospital site.

\section{Plant Dismantling}

When groundwater restoration for the last mining unit is completed, reclamation of the uranium recovery plant and the evaporation ponds can begin. Process buildings and equipment will be dismantled and decontaminated. Contaminated equipment can be sold to another licensed facility or disposed of at an NRClicensed facility. Decontaminated material can be sold for scrap or disposed of at an appropriate waste

\footnotetext{
${ }^{38}$ NRC Docket 40-8964; Rio Algom Mining Corp. Application for Source Materials License for Smith Ranch, documents of various dates. ${ }^{39}$ NRC Docket 40-8964; NRC Uranium Recovery Field Office and BLM Platte River Office; Environmental Assessment for Rio Algom Mining Corporation In Situ Leach Project (Converse County, WY, January 1992).

${ }^{40}$ NRC Docket 40-8964; Safety Evaluation Report Accompanying Issuance of a Source Material License to Rio Algom Mining Corporation Smith Ranch ISL Project, Feb 20, 1992.
} 


\section{Table C1. Distribution of Decommissioning Cost Components for a Nonconventional Production Facility}

(Thousand 1991 Dollars)

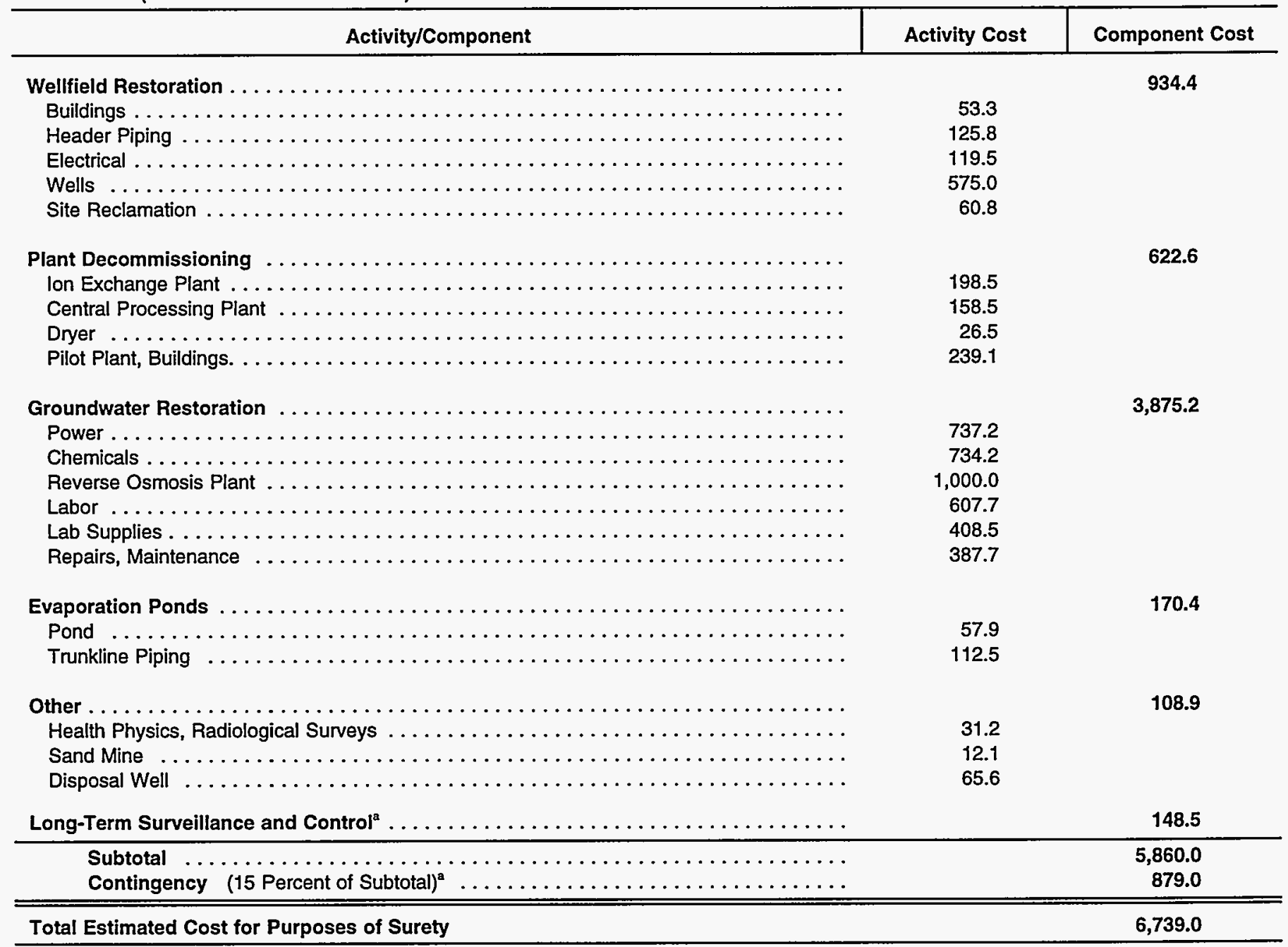

${ }^{a} E I A$ estimates based on nonconventional site data.

Note: Estimated costs are through 1996.

Source: Rio Algom filing with the U.S. Nuclear Regulatory Commission.

disposal site. Tanks and pipe will be cut up or crushed. Building materials of no commercial value, such as foundations, will be buried on site, and the foundation slab will be decontaminated with hydrochloric acid. The plant site will be recontoured, then surveyed to assure that radiation levels are acceptably low and that topsoiling and reseeding are adequate.

\section{Groundwater Restoration}

The goal is to restore the groundwater in a mining unit to the mean of the recorded baseline conditions or better. If this cannot be done for all parameters, the quality of the groundwater must at least be returned to the criteria set by the NRC or appropriate State agencies.

The primary restoration technique will be reverse osmosis, groundwater sweep, or both. Groundwater sweep extracts the wellfield solutions and draws natural groundwater toward the extraction well. Water sampling and volume calculations can indicate when this phase is completed.

In the groundwater sweep technique, water from the wellfield is processed in the ion exchange unit to remove any remaining uranium. Reverse osmosis is used to remove other dissolved solids. The clean water from this operation is then reinjected to the wellfield. 
The brine solutions generated are sent to the evaporation ponds.

These methods will be supplemented by the use of reductants where needed. Reductants-hydrogen sulfide, sodium hyposulfite, or sodium sulfide-are added in the middle phases of the restoration process to increase the level of total dissolved solids. This helps to reestablish the reducing (deoxidizing) conditions in the aquifer and immobilize metals such as arsenic, molybdenum, selenium, uranium, and vanadium, which may be above the baseline levels when mining is completed. It is expected that volumes of fluid equal to about 6 times the pore volume ${ }^{41}$ will be required to restore baseline conditions in the aquifer being restored.
After the restoration goals are achieved, there will be a period of extended sampling to assure stability. Samples will be taken of a full suite of parameters every 6 months. The same wells used for establishing baseline conditions will be used to determine whether restoration and stabilization have been achieved.

\section{Evaporation Ponds}

When the evaporation ponds are dry, the remaining solids and the liner will be removed and sent to a licensed disposal site. The ponds will be backfilled, recontoured to blend in the natural terrain, gamma surveyed, topsoiled and reseeded.

${ }^{11}$ For a definition of pore volume, see the Glossary. 
, 
Glossary 
, 


\section{Glossary}

Agreement State-State that is or has been a party to a discontinuance agreement with the Nuclear Regulatory Commission under Section 274 of the Atomic Energy Act (42 U.S.C. 2021) and thereafter issues licenses and establishes remedial action requirements pursuant to a counterpart to Section 62 or 81 of the Atomic Energy Act under its State laws.

Aquifer-Porous water-bearing formation (bed or stratum) of permeable rock, sand, or gravel capable of yielding significant quantities of water.

Ball Mill-A rotating, horizontal cylinder with a diameter almost equal to the length supported by a frame or shaft in which ores are ground using various types of grinding media (such as steel ball, quartz pebbles or porcelain balls).

Barren Solution-A solution in hydrometallurgical treatment from which all possible valuable constituents have been removed.

Bleed Solution-Solution drawn to adjust production or to restore groundwater by pumping more fluids from the production zone than are injected, creating an inflow of fresh groundwater into the production area.

Brine Solution-A concentrated solution containing dissolved minerals (usually greater than 100,000 $\mathrm{mg} /$ liter), especially chloride salts.

Byproduct Material-The tailings or wastes produced by the extraction or concentration of uranium or thorium from any ore processed primarily for its source material content. See also, Source Material.

Decantation-Process of separating sediments from liquid by settling solids below and pouring off liquids above.

Effluent-A waste liquid, solid, or gas, in its natural state or partially or completely treated, that discharges into the environment.

Elution-Activities of removing "elutes" a material (uranium) adsorbed on ion exchange resin from the "eluant" solution.
Evaporation Pond-A containment pond (that preferably has an impermeable lining of clay or synthetic material such as hypalon) to hold liquid wastes and to concentrate the waste through evaporation.

Failure-Refers to when a structure element can no longer fulfill the purpose for which it was designed.

Federally-related tailings-Mill tailings material that was presented at an active uranium or thorium processing site on October 24, 1992, and was generated as an incident of uranium or thorium sales to the United States.

Gangue-Worthless material, such as waste rock, in which valuable minerals (uranium or vanadium) are found.

Groundwater-Water beneath the surface in the saturated zone that is under atmospheric or artesian pressure.

Heavy Metals-Metallic elements, including those required for plant and animal nutrition, in trace concentration but which become toxic at higher concentrations. Examples are mercury, chromium, cadmium, and lead.

In Situ Leaching-The in-place mining of a mineral without removing overburden or ore, by installing a well and mining directly from the natural deposit thereby exposed to the injection and recovery of a fluid that causes the leaching, dissolution, or extraction of the mineral.

Ion Exchange-Reversible exchange of ions adsorbed on a mineral or synthetic polymer surface with ions in solution in contact with the surface. A chemical process used for recovery of uranium from solution by the interchange of ions between a solution and a solid, commonly a resin.

Injection Well-A well or a drill hole in an in situ leach operation through which barren solutions are entered into an underground stratum or ore body by gravity or under pressure. 
Leachate-The liquid that has percolated through the soil or other medium.

Lixiviant-Leachate solution pumped underground to a uranium ore body; it may be alkaline or acidic in character.

Marginal Cost-The cost of taking the next action available at any given level of activity (e.g., producing one more pound, opening one more mill, cleaning up one more tailings pile).

Mill Feed-Uranium ore supplied to a crusher or grinding mill in an ore-dressing process.

Mill Tailings—see Tailings.

Pachuca Tank-A cylindrical tank with a conical bottom used in slime leaching.

Permeability-The ease with which fluid flows through a porous medium.

Pore Space-The open spaces or voides of a rock taken collectively. It is a measure of the amount of liquid or gas that may be absorbed or yielded by a particular formation.

Pore Volume-Volume equal to the open space in rock or soil.

Pregnant Solution-A solution containing dissolved extractable mineral that was leached from the ore; uranium leach solution pumped up from the underground ore zone though a production hole.

Radon-Chemically inert radioactive gaseous element formed from the decay of radium. A potential health hazard.

Reclamation-Process of restoring surface environment to acceptable pre-existing conditions. Includes surface contouring, equipment removal, well plugging, revegetation, etc.

Relocation of Tailings-Relocation of tailings is sometimes necessary if the pile poses a threat to inhabitants or the environment, for example, through being situated too close to populated areas, on top of aquifers or other sources of water, or in unstable areas such as flood plains or faults near earthquake zones.

Reverse Osmosis-The act of reversing a diffusion through a semipermeable membrane, typically sep- arating a solvent and a solution, that tends to equalize their concentrations.

Restoration-The returning of all affected groundwater to its premining quality for its premining use by employing the best practical technology.

Rip Rap-Cobblestone or coarsely broken rock used for protection against erosion of embankment or gully.

Roll Front-A type of uranium deposition localized as a roll or interface separating an oxidized interior from a reduced exterior. The reduced side of this interface is significantly enriched in uranium.

Runoff-The portion of rainfall that is not absorbed by soil, evaporated, or transpired by plants, but finds its way into streams directly or as overland surface flows.

Scour Protection-Protection of trench surface from erosion by means of flushing water.

Source Material-Uranium or thorium ores containing 0.05 percent Uranium or Thorium regulated under the Atomic Energy Act. In general, this includes all materials containing radioactive isotopes in concentrations greater than natural and the byproduct (tailings) from the formation of these concentrated materials.

Surety-A type of bond to ensure that funds are available for a specific activity, in this case, dismantling, reclamation, restoration, and remediation of uraniumconcentrate production sites. In the event the company goes bankrupt, the bonding company pays the NRC or the appropriate state the amount of the bond. It is the responsibility of the NRC or the appropriate State to ensure that the amount is adequate for the remediation activities.

Tailings-The remaining portion of a metal-bearing ore consisting of finely ground rock and process liquid after some or all of the metal, such as uranium, has been extracted.

Trenching-Digging a long, narrow ditch to divert waterflow.

Wellfield-The area of an in situ leach operation that encompasses the array of injection and extraction wells and interconnected piping employed in the leaching process.

Yellowcake-Sludge of uranium oxide concentrate formed during the final step of the milling process. 